ALEXANDRE DE OLIVEIRA NETTO

COMPATIBILIDADE DE UM TRIBUTO AMBIENTAL COM O SISTEMA TRIBUTÁRIO NACIONAL

FACULDADE DE DIREITO

SÃO PAULO - SP

2014 


\title{
COMPATIBILIDADE DE UM TRIBUTO AMBIENTAL COM O SISTEMA TRIBUTÁRIO NACIONAL
}

\begin{abstract}
Dissertação de Mestrado apresentada perante o Departamento de Direito Econômico, Financeiro e Tributário - DEF, da Faculdade de Direito da Universidade de São Paulo - USP, como pré-requisito parcial e obrigatório para a obtenção do título de Mestre, sob a orientação do Prof. Associado Dr. Gerd Willi Rothmann.
\end{abstract}

FACULDADE DE DIREITO

SÃO PAULO - SP 


\section{COMPATIBILIDADE DE UM TRIBUTO AMBIENTAL COM O SISTEMA TRIBUTÁRIO NACIONAL}

Dissertação aprovada como requisito parcial para obtenção do grau de Mestre, perante o Departamento de Direito Econômico, Financeiro e Tributário - DEF, da Faculdade de Direito da Universidade de São Paulo - USP, pela Comissão formada pelos professores:

\section{Banca examinadora:}

1.

Professor Orientador

2.

Professor(a)

3.

Professor(a)

São Paulo, de de 2014. 


\section{AGRADECIMENTOS}

O desenvolvimento de uma pesquisa científica, seja em qual área do conhecimento for, sempre requer dedicação, empenho e renúncias por parte do pesquisador. Neste sentido, principalmente em relação às renúncias, as pessoas que mais sofrem com essas escolhas são àquelas que estão mais próximas do cientista, pois fomos nós cientistas quem escolhemos esse caminho, o qual por muitas vezes, além de toda carga emocional que envolve o desenvolvimento e término de um trabalho científico, ainda requer períodos de isolamento e distanciamento dessas mesmas pessoas.

Neste sentido, nada mais justo que ao término de um trabalho científico, logo no começo do trabalho se reconheça a importância dessas pessoas. Assim, em primeiro lugar agradeço a Deus e a meus pais, Sidney Netto e Wandete de Oliveira Netto, sem os quais não teria tido a oportunidade de ter permanecido durante todo esse tempo me dedicando simplesmente a pesquisa acadêmica e não teria tido os exemplos que me são tão caros de honestidade, determinação, integridade e, juntamente com minha irmã, Alessandra Netto, amor incondicional.

Não poderia deixar de agradecer ao Prof. Dr. Gerd Willi Rothmann, que prontamente me aceitou como seu orientando e demonstrou de forma clara, simples e despretensiosa a essência da figura de um verdadeiro Orientador. Além de todo o corpo docente da Faculdade de Direito da USP, em especial aos Professores Eduardo Faria, Fernando Scaff, Gerd Willi Rothmann, José Maurício Conti, Luís Eduardo Schoueri, Nina Beatriz Ranieri, Paulo Ayres Barreto, Paulo Bolhinha, com os quais tive a oportunidade de estudar e aprender diretamente. Além de todos os servidores administrativos da Faculdade de Direito.

Aos hoje amigos, que em momentos distintos me ajudaram desde o ingresso até o término do Curso de Mestrado, Prof. Dr. Carlos Alberto Ramos de Moraes Filho, quem me proporcionou o primeiro contato com o Direito Tributário, doutorando Paulo Victor Vieira da Rocha e Dr. Vallisney de Souza Oliviera. Aos amigos que conviveram comigo de forma mais próxima, nesse período tão intenso da minha vida, André Augusto de Almeida, Bruno Oliveira, Inácio de Oliveira Júnior, Luana Caroline, Rodrigo Machado e, de forma mais que especial, à Daniella Freitas. Obrigado! 


\section{SUMÁRIO}

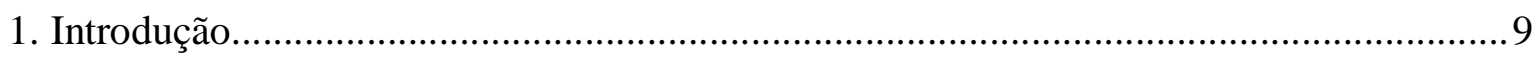

2. Extrafiscalidade e indução tributária.............................................................................19

2.1 Formas de intervenção econômica......................................................................24

2.1.1 Intervenção por indução.....................................................................26

2.1.2 Indução tributária e tributação do ilícito..................................................29

2.2 Desenvolvimento econômico..........................................................................

2.2.1 Desenvolvimento e meio ambiente.........................................................34

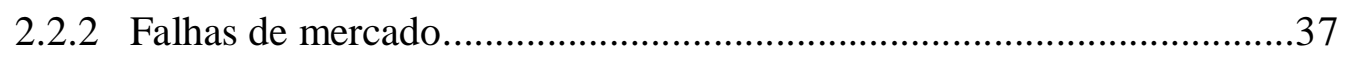

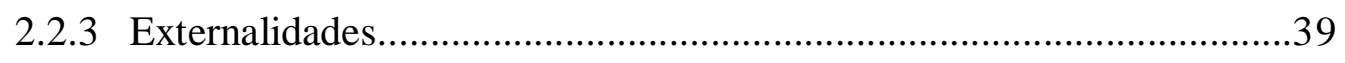

2.2.4 Duplo dividendo............................................................................42

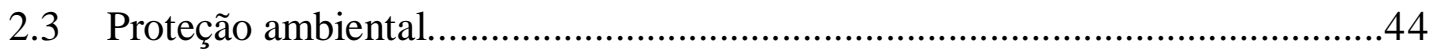

3 Ordem tributária, ordem econômica e defesa do meio ambiente......................................48

3.1 Noções de sistema tributário............................................................................

3.2 Princípios constitucionais relevantes............................................................53

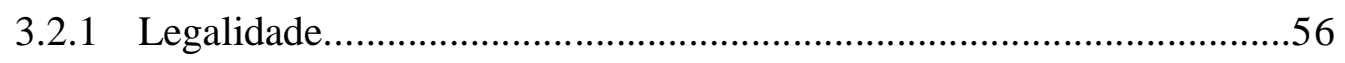

3.2.2 Igualdade e capacidade contributiva....................................................58

3.2.3 Livre concorrência...............................................................................64

3.2.4 Defesa do meio ambiente........................................................................68

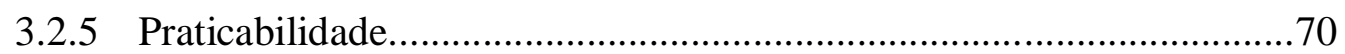

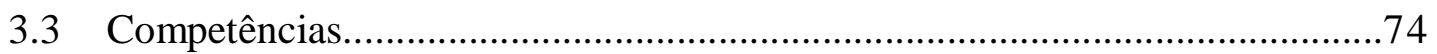

3.3.1 Competência tributária.....................................................................76

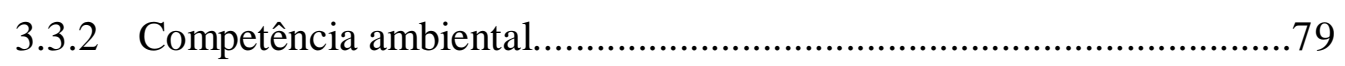

4 Tributação ambiental em ordenamentos estrangeiros...................................................82

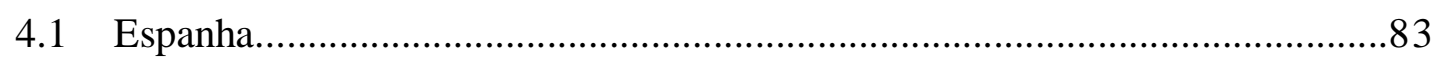

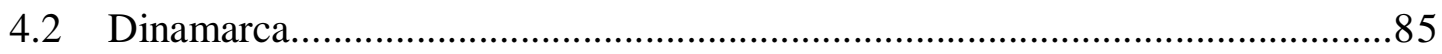

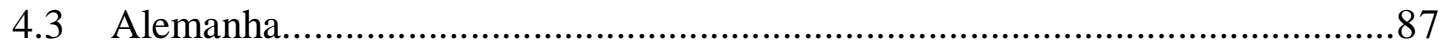

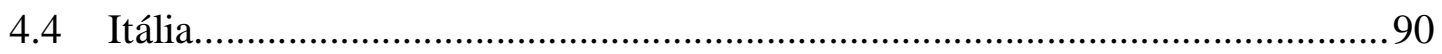

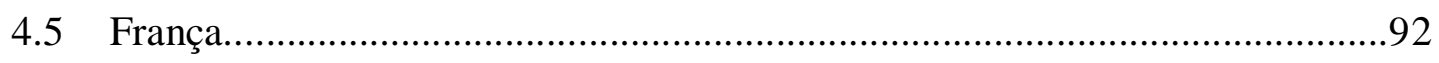

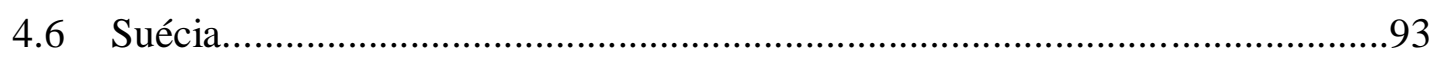

4.7 Estados Unidos da América..............................................................................94

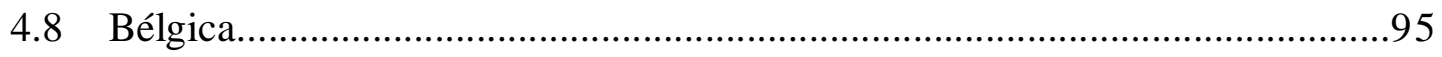




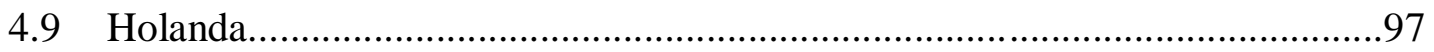

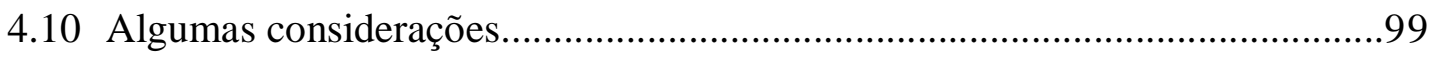

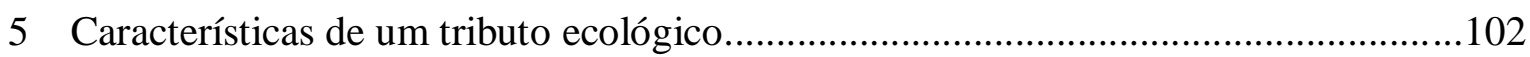

5.1 Espécies tributárias adequadas à tributação ambiental..................................102

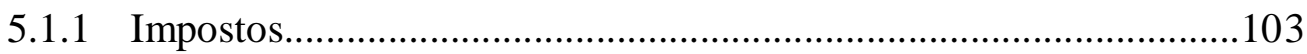

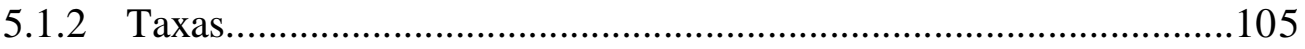

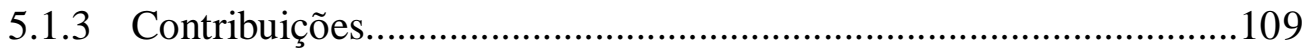

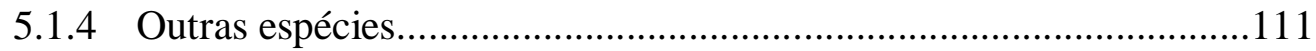

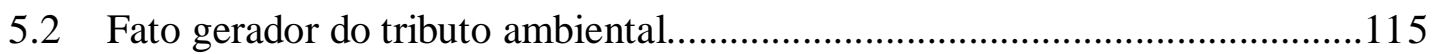

5.2.1 Aspecto material.................................................................... 120

5.2.2 Aspecto espacial.................................................................... 121

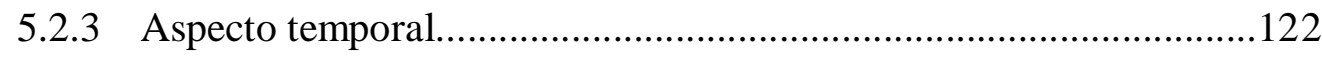

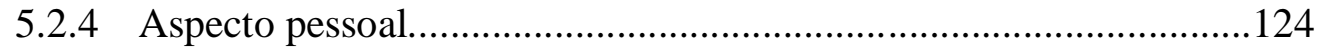

5.2.4.1 Aspecto quantitativo: base de cálculo e Alíquota............................126

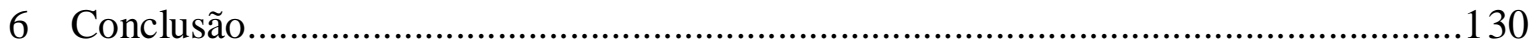

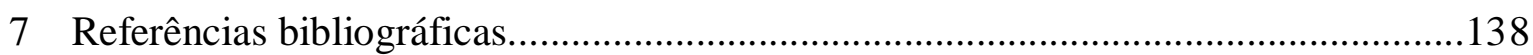




\section{RESUMO}

O ambiente ecológico do Planeta sofre incontáveis alterações, primordialmente, pela ação humana diante da transformação, consumo e descarte dos bens naturais. Tais atitudes resultam em significativa relevância na degradação ambiental e requerem imposição estatal a fim de controlar e/ou impedir maior devastação. Dentre as formas pelas quais o Estado pode combater o processo de poluição, encontram-se os chamados instrumentos econômicos. É exemplo deste mecanismo estatal o tributo ecológico, que desperta interesse em face de seu forte poder de indução comportamental. Embora, nesse aspecto, a utilização da tributação não seja ferramenta inédita, pode-se afirmar que foi com a substituição do Estado Liberal para o Estado Intervencionista que o uso da tributação com escopo de ajuste comportamental se enfatizou. Como o ordenamento jurídico brasileiro ainda não apresenta um verdadeiro tributo ecológico, da forma prevista e defendida pela OCDE - Organização para Cooperação e Desenvolvimento Econômico, o tema mostra-se atual e relevante, notadamente, pela experiência internacional que tem demonstrado a capacidade de alcançar resultados significativos no combate à poluição do meio ambiente natural por meio do tributo ecológico. Assim, a proposta do trabalho consiste em abordar a compatibilidade de um tributo ecológico com o sistema tributário nacional. Nesta seara, são abordados os temas relativos aos contornos da extrafiscalidade e da indução tributária, as formas de intervenção do Estado na economia e os seus limites, o desenvolvimento econômico, a proteção ambiental e as externalidades e, ainda, a relação entre a ordem tributária, a ordem econômica e a defesa do meio ambiente, presentes no texto constitucional, em especial, no que se refere aos princípios da legalidade, da igualdade, da livre concorrência e da defesa do meio ambiente. Igualmente, é objeto da pesquisa a análise da legislação estrangeira, por meio do direito comparado para investigação da mais adequada espécie tributária para fins de proteção ambiental. Em sede de conclusão, analisa-se acerca da compatibilidade ou não de um tributo ambiental com o sistema tributário nacional. Para melhor desenvolver o estudo, este último tópico é dividido em duas vertentes: uma teórica - acerca do sistema tributário nacional - e uma análise pragmática - acerca da sua exequibilidade. Assim, experimentam-se as espécies tributárias existentes no vigente sistema tributário a fim de verificar o veículo mais adequado a ser utilizado como um possível tributo ecológico.

Palavras-chave: tributo ambiental - compatibilidade - sistema tributário nacional 


\begin{abstract}
Earth's ecological environment undergoes countless changes, mainly brought about by human action on the processing, use and disposal of natural resources. Such attitudes result into a significant outstanding of the environmental degradation, requiring state ruling in order to control and/or prevent greater devastation. The so called economical instruments are among the ways through which the government is able to fight the polluting process. The ecological tax, which arouses interest on account of its strong environmental induction power, is one of the examples of such instruments. Although, under this aspect, the utilization of taxation is not an unheard of tool, one may assert it was through the substitution of the liberal government by the interventionist one that the use of environmental adjustment-scoped taxation, got to be emphasized. Since the Brazilian legal arrangement has yet to put forth an actual ecological tax, as it was foreseen and defended by OCDE - Economical Development and Cooperation Organization, the matter shows to be current and relevant, notably, by the international experience which has demonstrated its ability on reaching significant results in the fight against the natural environment's pollution by means of the ecological tax. Thus, the present study aims to address compatibility of an ecological tax with the National taxing system. In this scope it examines all issues pertaining the outlines of tax induction and extra fiscal measures forms of state intervention in the economy and its boundaries, economical development, environmental protection and their externalities. And yet, the relation among tax policy, economic policy and environmental protection as presented in the constitution, especially on what refers to legal, equity, free competition and environmental protection principles. Likewise, this research aims to analyze the foreign legislation, by means of comparing the right for investigating the most suitable tax for environmental protection purposes. In conclusion we analyze the compatibility, or not, of an environmental tax with the national tax system. So as to better develop this study, this latter issue is divided into two parts, a theoretical one - about the national tax system - a pragmatic one - and about their feasibility. Thus, experience whether existing taxes on the current tax system in order to ascertain the most suitable one for being used as a possible ecological tax.
\end{abstract}

Keywords: Environmental tax - compatibility - Brazilian tax system 


\section{INTRODUÇÃO}

Podemos afirmar que é consenso mundial, salvo opinião de alguns céticos, que as ações humanas, especialmente ao longo dos dois últimos séculos, trouxeram inúmeras transformações ao Planeta. Algumas dessas transformações advieram com ares de irreversibilidade, especialmente as referentes às mudanças climáticas, escassez de recursos naturais e extinção de espécies animais e vegetais. Aquecimento global, com o consequente derretimento das calotas polares, extinção de espécies animais e vegetais, poluição dos rios, dos mares e do ar, desertificação de áreas de florestas, isto é, inúmeros problemas ambientais em proporções e velocidade nunca antes vistos, atualmente, são uma realidade e não mais uma mera conjetura.

É seguro asseverar que as mudanças no ambiente ecológico do Planeta são influenciadas, de forma direta, em razão do aumento da população mundial e do modo como a humanidade vem transformando, consumindo e descartando os bens naturais. Nesse sentido, o uso indiscriminado e sem maiores preocupações dos bens naturais, dos processos produtivos e o descarte dos rejeitos, sobras e resíduos, tanto dos bens de consumo quanto dos bens de produção, tiveram e continuam tendo papel significativo na degradação ambiental. Assim, essa é uma realidade na qual o homem teve, tem e terá um papel determinante, seja qual for o seu desfecho.

De forma extremada, existem apenas dois caminhos a serem seguidos: o primeiro é o da assimilação da consciência ambiental e mudança dos atuais padrões de desenvolvimento econômico para um modelo de desenvolvimento econômico ecológicosustentável. O segundo é o da manutenção do pensamento ultrapassado que predominou durante a segunda metade do século XVIII, durante todo o século XIX e meados do século XX. Essa linha de pensamento acreditava num Planeta com recursos naturais infinitos, de modo que desenvolvimento econômico era tido como sinônimo de puro crescimento econômico, ou simples produção de riquezas. Ocorre que este segundo caminho, fatalmente, nos levará a um cenário de aumento e agravamento dos problemas ambientais e irá gerar, por consequência, inúmeros outros problemas econômico-sociais.

É óbvio que a solução para tal problema não é fácil, tampouco simples, e não há como se afirmar que exista uma única medida a ser tomada e, mesmo adotada, o problema estará solucionado. A resposta dessa equação passa, necessariamente, por uma série de questões complexas, tais como o desenvolvimento de novas tecnologias e o custo dessas novas tecnologias, os padrões de crescimento e de desenvolvimento econômico dos 
Estados, a educação e a assimilação da consciência ambiental dos indivíduos, entre outras questões políticas, tecnológicas, econômicas e sociais. Portanto, o assunto é extremamente complexo e demanda a integração dos vários ramos do conhecimento, tais como os das Ciências Naturais, Sociológicas, Econômicas e da própria Ciência Jurídica.

Apesar de a solução para os problemas ambientais requerer, obrigatoriamente, um percurso interdisciplinar pelos vários ramos do conhecimento, podemos afirmar que os maiores entraves se encontram no campo econômico. Essa ligação entre economia e meio ambiente $^{1}$ é natural, visto que a natureza, como matéria-prima, com o capital e o trabalho formam o tripé da atividade econômica. Por essa razão, Cristiani Derani afirma que o direito econômico, assim como o direito ambiental, são dois ramos indissociáveis. A autora vai mais além e assevera que esses dois ramos da ciência jurídica possuem a mesma finalidade: o aumento do bem-estar ou qualidade de vida individual e coletiva. ${ }^{2}$

Assim, o comportamento humano, especialmente no que diz respeito ao consumo e à produção industrial, tem relação direta com o comprometimento do equilíbrio ecológico do planeta. Nesse contexto, infere-se que a questão da proteção ambiental está substancialmente interligada à economia e ao desenvolvimento econômico dos Estados, ou, em outras palavras, os principais problemas ambientais estão substancialmente ligados a dificuldades econômicas.

Nesse sentido, não por acaso, ao lado dos antigos instrumentos de defesa do meio ambiente, conhecidos como instrumentos de controle ou comando-controle, surgiram, há pouco tempo, os chamados instrumentos econômicos de defesa do meio ambiente.

Em síntese, os instrumentos de controle são entendidos como aqueles que fixam normas, regras, procedimentos e padrões determinados para as atividades econômicas, cuja finalidade é assegurar o cumprimento dos objetivos que o ente estatal entende serem adequados para reduzir a poluição, traçam verdadeiros limites à emissão de poluentes, ou determinam os procedimentos a serem adotados para o descarte de determinados produtos. Tais instrumentos são consubstanciados no poder de polícia do Estado e cujo descumprimento acarreta sanções de cunho penal e/ou administrativo. ${ }^{3}$

\footnotetext{
${ }^{1} \mathrm{O}$ termo meio ambiente será utilizado neste trabalho no sentido de meio ambiente natural, ecológico. Tal explicação se faz necessária tendo em vista certa imprecisão terminológica e, até certa forma, redundante da expressão meio ambiente, como adverte José Afonso da Silva, "a palavra 'ambiente' indica a esfera, o circulo, o âmbito que nos cerca, em que vivemos. Em certo sentido, portanto, nela já se contém o sentido da palavra 'meio'. Por isso, até se pode reconhecer que na expressão 'meio ambiente' se denota certa redundância." Direito Ambiental Constitucional. $8^{\text {a }}$ ed., São Paulo: Malheiros Editores, 2010, p. 17.

${ }^{2}$ DERANI, Cristini. Direito ambiental econômico. $3^{\text {a }}$ ed., São Paulo: Saraiva, 2008, p. 21.

${ }^{3}$ NUSDEO, Ana Maria de Oliveira. O uso de instrumentos econômicos nas normas de proteção ambiental. In Revista da Faculdade de Direito, Universidade de São Paulo, v. 101, 2006, 357 - 378, p. 364.
} 
Enquanto os instrumentos econômicos podem ser entendidos, em síntese, como os que atuam diretamente nos custos de produção e consumo dos agentes, cujas atividades estejam inseridas nos objetivos da política ambiental do ente estatal. ${ }^{4}$ Como exemplo desses instrumentos, podemos destacar como principais: a) as ajudas financeiras, seja por meio de subvenções, créditos facilitados com taxas menores que as de mercado ou deduções fiscais; $b$ ) os sistemas de consignação ou caução-reembolso, que consistem em aplicar uma sobrecarga no preço dos produtos potencialmente contaminantes, a qual é reembolsada após se cumprirem certas condições predeterminadas pela política ambiental; c) a criação de mercados, que podem ser consubstanciados na compra e venda de direitos de emissões ou direitos de poluir; na própria intervenção direta no mercado e estabilização dos preços de produtos que não reflitam fielmente o seu valor ambiental; nos seguros de responsabilidade, mediante os quais se transferem para as companhias de seguros os riscos de penalização por danos ambientais futuros e incertos; e, finalmente, $d$ ) por meio dos tributos. ${ }^{5}$

Dentre as inúmeras formas de que o Estado dispõe para combater a degradação ambiental, os chamados instrumentos econômicos vêm ganhando um destaque maior, especialmente ao longo das últimas décadas. O tributo ecológico, um desses instrumentos, tem sido alvo de considerável interesse, particularmente em função do seu forte poder de indução comportamental, embora também seja um dos instrumentos de defesa do meio ambiente que mais tem causado discussões, tanto teóricas quanto práticas.

O uso da tributação como instrumento de indução de comportamentos não é novo. Luís Eduardo Schoueri noticia que há registros do uso de impostos com a finalidade de desestimular determinados comportamentos desde o império romano. ${ }^{6}$ No entanto, foi com a substituição do Estado Liberal para o Estado Intervencionista, em especial nos períodos do pós-guerra, que o uso da tributação com finalidade indutora de comportamentos ganhou força.

Assim, percebeu-se que a tributação deixara de ser um mero instrumento fiscal, com o simples fim de prover o erário público com os recursos necessários para a satisfação dos seus gastos, e passou a ser um importante instrumento de implementação de políticas

\footnotetext{
${ }^{4}$ Idem, p. 365.

${ }^{5}$ HERNÁNDEZ, Jorge Jiménez. El tributo como instrumento de protección ambiental. Granada: Editorial COMARES, S.L., 1998, p. $58-60$.

6 SCHOUERI, Luís Eduardo. Normas tributárias indutoras e intervenção econômica. Rio de Janeiro: Forense, 2005, p. 109.
} 
públicas e sociais, por meio da chamada extrafiscalidade. Nesse sentido, a tributação ambiental está inserida, uma vez que ela possui um nítido caráter extrafiscal.

A doutrina tributária utiliza o termo tributo ambiental de forma genérica, seja para referir-se a um tributo ordinário que tenha algum critério de diferenciação ecológica, seja para referir-se a um tributo que incida diretamente sobre a emissão de poluentes. Tais situações são bem diferentes uma das outras e não se confundem.

José Marcos Domingues faz essa distinção quando atribui à expressão tributo ambiental um sentido lato e um sentido estrito. $\mathrm{O}$ autor afirma que tributo ambiental, em sentido amplo, seria o uso dos tributos ordinários ou tradicionais, já existentes no ordenamento jurídico, adaptados de forma a serem utilizados com o fim de proteger o meio ambiente, enquanto em sentido estrito, tributo ambiental seria um tributo novo, cobrado em razão do uso do meio ambiente pelos agentes econômicos. ${ }^{7}$

Levando-se em consideração a divisão da tributação ambiental em sentido amplo e sentido estrito, é importante destacarmos que o objeto central desta pesquisa limita-se ao que a doutrina chama de tributo ambiental em sentido estrito, o tributo novo cobrado em razão do uso do meio ambiente. No entanto, neste trabalho, optamos pelo termo tributo ecológico, visto que apenas o termo tributo ambiental pode gerar ambiguidade ou confusão, além de entendermos que o vocábulo ecológico representa melhor a ideia por trás da referida tributação, que consiste em tributar uma ação que afete diretamente um elemento ecológico natural. Acrescente-se a isso, o fato de acreditarmos que este termo está mais alinhado com as expressões utilizadas na doutrina internacional, quais sejam "environmental taxation" e "green taxation".

Quando formos referir-nos à tributação ambiental em sentido lato, isto é, o uso de tributos ordinários adaptados para a defesa do meio ambiente, iremos utilizar a expressão tributação ambientalmente orientada. E, o uso do termo tributação ambiental, deverá ser entendido como genérico, em que estão inseridos os dois sentidos expostos.

A Organização para Cooperação e Desenvolvimento Econômico - OCDE, em conjunto com a Agência Europeia do Ambiente - AEA, vêm estudando a tributação ambiental, em especial, os tributos ecológicos já há algumas décadas. Com base nesses estudos, os dois organismos internacionais chegaram à conclusão de que uma das grandes vantagens deste instrumento é a correção das distorções dos preços de mercado ao se incorporarem os custos da produção e outros custos ambientais nos preços isto é, um

\footnotetext{
${ }^{7}$ OLIVEIRA, José Marcos Domingues de. Direito tributário e meio ambiente. $3^{\mathrm{a}}$ ed., Rio de Janeiro: Forense, 2007, p. 63/64, grifos originais.
} 
processo de "correção de preços" e, simultaneamente, de aplicação do "princípio do poluidor-pagador". 8

Some-se a isso, o fato de essa vantagem ter sido reconhecida nas conclusões do Conselho "Ambiente", em dezembro de 1991, quando se estabeleceu a plataforma comum da Comunidade Europeia para a Conferência da Organização das Nações Unidas ONU sobre Ambiente e Desenvolvimento, em 1992, a ECO - 92, no Rio de Janeiro. Desde então, o uso dos tributos ecológicos tem aumentando constantemente.

Desde o começo dos anos 1990, principalmente nos países-membros da OCDE, vem sendo implantada a chamada reforma tributária ecológica (RFE), ou environmental tax reform (ETF), ou, ainda, green tax reform $(G T F)$. Vários países-membros já fizeram as suas respectivas reformas e alcançaram significativos resultados. Suécia, Finlândia, Noruega, Itália, Dinamarca, Países Baixos, França, Alemanha, Suíça e Reino Unido são exemplos de países que fizeram algum tipo de reforma fiscal ecológica.

A Comissão Europeia e a OCDE elaboraram um Manual de estatísticas sobre tributação ecológica. Esse documento contém, entre outras informações, algumas definições e classificações elaboradas em consenso pelos seus participantes. Uma dessas definições é acerca do tributo ecológico. Para que assim seja considerado, o tributo deverá ter na sua base de cálculo uma unidade física (ou um substituto desta) de alguma coisa que, quando usada ou despejada, tenha um comprovado e específico impacto ambiental negativo. É considerada impacto ambiental negativo a deterioração de recursos ambientais até então gratuitos ou a redução da oferta de tais recursos. Essa unidade física pode ser uma unidade de substância poluente emitida (p. ex., $1 \mathrm{~kg}$ de NOx) ou uma unidade aproximada para emissões (p. ex., 1 litro de gasolina consumida em um motor padrão ou um veículo com determinada especificação de emissões) ou uma unidade de recurso natural limitado (p. ex., água doce). O impacto ambiental negativo específico e comprovado será constituído pelo nexo causal entre a unidade física e a degradação ambiental. $^{9}$

O Brasil começou a dar maior atenção a essa tendência mundial há pouco tempo, no entanto, já é possível notar que algumas iniciativas exitosas têm sido

\footnotetext{
${ }^{8}$ AGÊNCIA EUROPEIA DO AMBIENTE - AEA. Taxas ambientais: implementação e eficácia ambiental. Copenhagen, Dinamarca, 1999, http://www.eea.europa.eu/pt/publications/92-9167-000-6-sum/page001.html

${ }^{9}$ EUROPEAN COMMISSION. Manual: Statistics on Environmental Taxes. Version 3.0, p. 3.
} 
implementadas, como é o caso do chamado ICMS - ecológico ${ }^{10}$, instituído, primeiramente, pelo Estado do Paraná, por volta de $1990 .^{11}$

Apenas para esclarecermos as diferenças entre os institutos, esse instrumento é, na verdade, um instrumento de direito financeiro, portanto não pertence à categoria de tributação ambientalmente orientada, nem à de tributo ecológico, mas estabelece critérios ecológicos para a entrega de parte pertencente aos municípios dos recursos oriundos da arrecadação total do ICMS. A Constituição Federal estabelece, no art. 158, IV, que um quarto do produto arrecadado do ICMS pertence aos municípios. Deste um quarto, a própria Constituição estabelece a forma de divisão de três quartos, art. 158, parágrafo único, I. Os critérios de divisão da quarta parte restante são de competência dos Estados e ao Distrito Federal, art. 158, parágrafo único, II. Com base nesse espaço de autonomia discricionária, os entes federativos podem estabelecer critérios ecologicamente diferenciados para a distribuição da parcela do chamado ICMS ecológico aos Municípios.

Outro exemplo de tributo ordinário com certa preocupação ambiental é o do art. $177, \S 4^{\circ}$, II, b da Constituição, que previu a instituição da chamada CIDE combustíveis e vinculou parte do produto da sua arrecadação ao financiamento de projetos ambientais relacionados com a indústria do petróleo e do gás.

Em 2009, foi protocolada a PEC 353/2009, de autoria do Deputado Roberto Rocha, cujo objetivo específico é introduzir a chamada reforma tributária ecológica no ordenamento jurídico pátrio. Um dos motivos expostos na justificação da proposta foram, exatamente, as reformas fiscais ecológicas feitas pelos países-membros da OCDE, acima mencionada.

Apesar de, no ordenamento jurídico brasileiro, ainda não existir um verdadeiro tributo ecológico, da forma como previsto e defendido pela OCDE, apresentado anteriormente, o tema mostra-se atual e relevante, visto que a experiência internacional tem demonstrado que o uso desse instrumento tem sido capaz de alcançar resultados significativos no combate à poluição do meio ambiente natural. ${ }^{12}$

Dessa forma, como a tributação ecológica já é realidade em ordenamentos alienígenas, tem alcançado resultados satisfatórios e demonstrado forte potencial para a

\footnotetext{
${ }^{10}$ Ver SCAFF, Fernando Facury; TUPIASSU, Lise Vieira da Costa. Tributação e políticas públicas: o ICMS ecológico, in Direito tributário ambiental. TÔRRES, Heleno Taveira. (org.), São Paulo: Malheiros Editores, 2005, p. $724-748$.

${ }_{11}$ Atualmente, mais da metade dos vinte e sete Estados brasileiros possuem o chamado ICMS ecológico, segundo o site http://www.icmsecologico.org.br/

${ }_{12}$ PORFÍRIO JÚNIOR, Nelson de Freitas. Responsabilidade do Estado em face do dano ambiental. Dissertação de mestrado da Faculdade de Direito da USP. São Paulo, 1999, p. 125-126.
} 
proteção do meio ambiente, além de ser uma crescente tendência mundial, ${ }^{13}$ de forma que é natural esse tipo de tributo ganhe espaço em nosso ordenamento jurídico. Assim, em função da real possibilidade de que eles venham a ser criados em nosso ordenamento jurídico, vislumbramos a importância e a atualidade do trabalho. No entanto, sem a pretensão de querer esgotar o tema, procuraremos, apenas, contribuir com o debate da implantação de um verdadeiro tributo ecológico no ordenamento pátrio e deixar a questão em aberto para futuras pesquisas científicas.

Assim, a proposta do trabalho consiste em abordar a compatibilidade de um tributo ecológico com o sistema tributário nacional e as principais dificuldades dessa imposição. Importante frisar que o termo compatibilidade deve ser encarado no seu sentido mais amplo, tanto compatibilidade teórica, isto é, a possibilidade em tese de o atual sistema tributário permitir a imposição de um tributo, cujo fato gerador seja a própria poluição, analisando-se a constitucionalidade de um tributo nesses termos, quanto no seu aspecto prático, isto é, se seria praticável a criação de um tributo sobre a poluição, da forma como o ordenamento jurídico tributário pátrio está positivado.

$\mathrm{Na}$ busca de tal objetivo da premissa de que os tributos ecológicos possuem um nítido caráter extrafiscal. No primeiro capítulo, abordaremos os contornos da extrafiscalidade e da indução tributária, as formas de intervenção do Estado na economia e os seus limites, o desenvolvimento econômico, a proteção ambiental e as externalidades. Nesse contexto, será apresentada uma correlação entre esses tópicos, além da utilidade e da eficiência do tributo como instrumento de indução comportamental, bem como de correção ou mitigação de efeitos indesejados, tais como as externalidades negativas.

É pacífico que os problemas ambientais estão intimamente ligados a problemas de aspecto econômico, em especial, a questões de desenvolvimento econômico, e, dessa forma, sabendo quão complexa é a relação entre a ordem tributária, a ordem econômica e a defesa do meio ambiente, no capítulo seguinte, iremos analisar como se dá esta interação na própria Constituição Federal.

A fim de que fique clara a ideia de integração das ordens tributária, econômica e defesa do meio ambiente, ainda neste segundo capítulo, faremos algumas breves considerações acerca da ideia de sistema jurídico e sistema tributário. Em seguida, iremos ater-nos aos princípios constitucionais que nos parecem mais relevantes para a eventual

13 OECD (2012), "Environmental tax and green growth", in Southeast Asian Economic Outlook 2011/12, OECD Publishing. http://dx.doi.org/10.1787/9789264166882-en acessado em 15.11.2013. p. 197 - 219. 
imposição da tributação ecológica. Em nosso entendimento, são os princípios da legalidade, capacidade contributiva como corolário da igualdade, livre concorrência, defesa do meio ambiente e praticabilidade.

A análise do princípio da capacidade contributiva reveste-se de especial importância em razão do nítido caráter extrafiscal dos tributos ecológicos, uma vez que, por si só, a emissão de poluentes não pode ser considerada como uma fonte de riqueza, o que, em tese, já impediria tal imposição. No entanto, há quem defenda que quando se trata de tributo que não vise, precipuamente, à arrecadação, mas tenha como objetivo outros fins constitucionalmente previstos, o princípio da capacidade contributiva poderia ser afastado.

Saber se e como a livre concorrência é afetada por um tributo ecológico é, também, extremamente relevante porquanto é possível que algumas tecnologias ecologicamente corretas sejam tão caras e quem os instalou tenha um custo maior do que quem decida arcar com o custo do tributo ecológico. Nesse sentido, é importante entendermos se tal situação afronta ou não o princípio da livre concorrência.

Dentro de tal contexto, um ponto crucial também não poderia deixar de ser analisado: a questão da competência tributária associada à competência ambiental. Na Federação brasileira, enquanto a competência tributária é taxativamente delimitada pela Constituição Federal, ${ }^{14}$ a competência ambiental, não, visto que se divide em material e legislativa. A competência material pode ser exclusiva ou comum, enquanto a competência legislativa pode ser privativa ou suplementar ${ }^{15}$, de modo que entender o funcionamento dessa repartição de competências é essencial para os fins do trabalho.

A junção da competência tributária com a competência ambiental é tida como fator essencial para possibilidade de se instituir um tributo ambiental. Dessa forma, iremos analisar como se dá essa repartição de competências no sistema constitucional brasileiro e verificar se existem obstáculos à junção dessas competências. Ainda neste capítulo, iremos analisar como a Constituição Federal tratou o tema das competências tributária e ambiental, uma vez que a criação de um tributo ecológico pressupõe essas duas competências.

Como já fora dito, nosso ordenamento jurídico ainda não possui um verdadeiro tributo ecológico. Por essa razão, iremos valer-nos do método do direito comparado para analisar as experiências alienígenas. A investigação por meio do direito comparado mostra-

\footnotetext{
${ }^{14}$ No que se refere aos impostos, o constituinte outorgou à União a competência para instituir os impostos não expressamente previstos no texto constitucional, a chamada competência residual, art. 154, I.

${ }^{15}$ SILVA, José Afonso da. Direito ambiental constitucional. $8^{a}$ ed., São Paulo: Malheiros Editores, 2010, p. 72.
} 
se como uma técnica muito útil, principalmente, ao se verificar qual a tendência dos Estados mais evoluídos nesse tipo de tributação dessa forma, poderemos observar os principais problemas que foram ou continuam sendo enfrentados na implantação e na administração desses tributos, se existe alguma tendência em se tributar esta ou aquela substância nociva e, especialmente, de que forma se dá essa tributação, ou, ainda, se cada Estado tributa uma fonte poluidora diferente.

Após a análise da legislação estrangeira, por meio do direito comparado, pretendemos escolher o tributo mais comum na doutrina estrangeira, isto é, o típico tributo ecológico dos Estados analisados, para, então, efetivamente, analisarmos as características de um tributo ecológico.

Assim, dividimos esta análise em duas grandes seções: a primeira será relativa ao exame de quais espécies tributárias poderiam ser adequadas a um eventual tributo ecológico no nosso sistema tributário. A segunda será relativa às características do fato gerador de um tributo ambiental, com a análise de todos os seus aspectos: material, espacial, temporal, pessoal e quantitativo. Nesse contexto, insere-se a compatibilidade prática, pois é essencial investigarmos qual seria a espécie tributária mais adequada para um tributo ambiental, explorando todos os aspectos da hipótese de incidência. Para, finalmente, podermos analisar se tal tipo de tributo é realmente compatível com o nosso atual Sistema Tributário Nacional, serão verificadas quais espécies são mais adequadas a tributar a poluição no Brasil.

Por fim, no capítulo próprio das conclusões, nós nos manifestaremos acerca da compatibilidade ou não de um tributo ambiental com o sistema tributário nacional e se, além de ser compatível, um tributo nesses moldes seria praticável num sistema tão complexo e intrincado como o nosso, os limites que entendemos devam ser observados e os principais problemas a serem enfrentados.

A metodologia a ser utilizada na pesquisa será bibliográfica documental, porque iremos analisar, sistematizar e expor documentos teóricos, como obras doutrinárias, periódicos científicos, inclusive eletrônicos, textos normativos e pesquisas elaboradas por organismos e organizações internacionais, até mesmo as publicadas nos seus sítios oficiais.

Será descritiva, porque iremos analisar determinados fenômenos, definir seus pressupostos e descrever as possíveis relações com outras variáveis e as normas jurídicas pertinentes, em especial, as inseridas no sistema tributário nacional. Na ideia de outras variáveis, podemos elencar a interdisciplinaridade da pesquisa, mais especificamente, a integração com o ramo das Ciências Econômicas. Visto que a questão da tributação 
ambiental e da preservação ambiental reflete, inevitavelmente, em questões econômicas, tais como o desenvolvimento econômico sustentável e a internalização das externalidades.

Apesar de optarmos por uma visão dogmática, a qual se preocupa com possibilitar uma decisão e orientar a ação diante do ordenamento vigente ${ }^{16}$ é importante salientar, desde logo, que em razão da falta de uma base normativa própria a respeito da tributação ecológica em nosso ordenamento jurídico, iremos valer-nos das definições encontradas na doutrina, tanto nacional quanto estrangeira, e nos organismos internacionais, como a OCDE.

O método de investigação do direito comparado ser-nos-á muito útil porque, como já fora dito, não possuímos, em nosso ordenamento jurídico, um verdadeiro tributo ecológico. Assim, iremos valer-nos da pesquisa na doutrina estrangeira para analisar como esse tipo de imposição ocorre. No entanto, é necessário alertar que não defendemos a simples importação de soluções ou de institutos jurídicos para o nosso ordenamento. Apenas analisaremos os institutos jurídicos alienígenas à luz do nosso ordenamento, quando for possível, mas sempre fazendo as devidas ressalvas e observações necessárias.

${ }^{16}$ FERRAZ JÚNIOR, Tercio Sampaio. Introdução ao estudo do direito: técnica, decisão, dominação. $6^{\mathrm{a}}$ ed., São Paulo: Atlas, 2010, p. 19 e 20. 


\section{EXTRAFISCALIDADE E INDUÇÃO TRIBUTÁRIA}

Antes de adentramos, efetivamente, no tema da extrafiscalidade e da indução tributária, entendemos ser necessário, ainda que de forma breve, abordarmos algumas questões acerca da ideia de neutralidade tributária, e do conceito, ou classificação, dos tributos em "fiscais" e "extrafiscais". De maneira mais específica, interessa-nos analisar a evolução do conceito de neutralidade tributária e como se dá a interação da neutralidade tributária com a extrafiscalidade na atualidade.

Até meados do século XIX, a chamada neutralidade tributária era entendida com a interpretação dada pelos estudiosos das Ciências das Finanças, ou seja, predominava a ideia no sentido da não interferência, ou abstenção, do Estado sobre o domínio econômico. Do ponto de vista ideal, num modelo de mercado perfeito, a tributação não deveria interferir no comportamento dos agentes econômicos e, por consequência, não deveria interferir no próprio funcionamento do mercado.

A ideia de neutralidade tributária desponta como uma marca do Estado Liberal. Se, no Estado Absolutista, o soberano, o rei, era o detentor de todos os poderes do Estado, no Estado Liberal, exatamente pelos direitos e vitórias alcançadas pelo povo por meio de revoluções, tal situação não poderia continuar. Dessa forma, o poder passa das mãos do Rei para as mãos do povo, ou melhor, da burguesia ${ }^{17}$. Nesse contexto, durante o período em que vigorou o Estado Liberal, a política econômica era determinada no sentido de que o Estado não interviesse nos negócios privados e deixasse que eles fluíssem ao sabor do próprio mercado. $^{18}$

O lema da doutrina econômica do Estado Liberal, laisser faire, laisser passer, “deixar fazer, deixar passar", representa de forma muito clara o pensamento dos teóricos liberais, os quais eram contra toda e qualquer forma de intervenção do Estado na economia. ${ }^{19}$ Os pensadores liberais tinham o mercado como o seu bem mais precioso e por isso, este deveria ficar imune a qualquer interferência do Estado, pois se acreditava na autossuficiência do mercado. Para esses teóricos, o próprio mercado seria capaz de adaptar-se e superar eventuais obstáculos.

\footnotetext{
${ }^{17}$ SIQUEIRA, Natercia Sampaio. Tributo, mercado e neutralidade no Estado Democrático de Direito. Rio de Janeiro, Lumen Juris, 2012, p. 7.

${ }^{18}$ SCAFF, Fernando Facury. Responsabilidade do Estado intervencionista. São Paulo: Saraiva, 1990, p. 27.

${ }^{19}$ Ibidem, p. 29.
} 
Adam Smith, um dos maiores defensores da autossuficiência do mercado e um dos mais importantes pensadores da época do Estado Liberal, acreditava que o mercado era guiado por uma espécie de "mão invisível" que seria a responsável por guiar o mercado e fazer com que ele não fosse atingido por crises, ou, caso fosse atingido, o próprio mercado seria capaz de superá-las. Smith acreditava que quanto mais um indivíduo buscasse a satisfação própria, mais ele estaria contribuindo para o benefício da comunidade em geral. $^{20}$ Nesse sentido, a autonomia e a liberdade do indivíduo para contratar eram fundamentais e, como consequência, o Estado deveria estar mais distante e não influenciar na escolha dos particulares.

Assim, se ao Estado não era legítimo intervir diretamente na economia, também não era legítimo que ele empregasse os tributos na consecução desse fim. A tributação não deveria interferir na dinâmica do mercado. Ao Estado, apenas era legítimo cobrar o mínimo suficiente para a sua própria manutenção e assegurar a ordem pública. ${ }^{21}$ Nesse contexto, é importante destacar que o Estado Liberal não era promotor de direitos sociais. À época, apenas eram assegurados os chamados direitos fundamentais de primeira geração, vinculados à liberdade do indivíduo e tidos como direitos de resistência e oponíveis ao próprio Estado. ${ }^{22}$

Porém, com o passar do tempo, percebeu-se que o mercado não era autossuficiente, tampouco imune às crises econômicas que foram uma das grandes responsáveis para a transformação do Estado Liberal em um Estado Intervencionista. Se, num primeiro momento, os indivíduos e empresários faziam questão de que o Estado se abstivesse de regular ou intervir no mercado, num segundo momento, eles mesmos clamavam por uma intervenção do Estado, a fim de que o mercado não entrasse em colapso total. Cabral de Moncada afirma que, para o mercado funcionar adequadamente, ele não pode ficar entregue a si próprio, mas necessita de uma disciplina jurídica para poder permanecer como mercado. ${ }^{23}$

Superada a fase Liberal e com ela a ideia da neutralidade da tributação, ao menos no sentido de que os tributos não poderiam interferir sobre as decisões de mercado, a neutralidade tributária ganha novos contornos. Atualmente, é pacífico que toda forma de

${ }^{20}$ SMITH, Adam. A riqueza das nações, volume 1. Tradução Alexandre Amaral Rodrigues, Eunice Ostrensky. Martins Fontes: São Paulo, 2003, p. 87 seq.

${ }^{21}$ CORREA, Walter Barbosa. Contribuição ao Estudo da Extrafiscalidade. São Paulo: Departamento de Direito Econômico e Financeiro - USP, 1964, p. 41.

${ }^{22}$ BONAVIDES, Paulo. Curso de Direito Constitucional. $24^{a}$ ed., São Paulo: Malheiros Editores, 2009, p. 563.

${ }^{23}$ MOCADA, Luís S. Cabral de. Direito econômico. $5^{\text {a }}$ ed. Coimbra: Editora Coimbra, 2007, p. 8. 
tributação sempre acaba por gerar alguma espécie de efeito sobre o domínio econômico, ${ }^{24}$ seja um efeito maior ou menor, de forma intencional ou não, ou mesmo por alguma espécie de distorção sistêmica.

Assim, percebida que a tributação sempre acaba por gerar algum tipo de efeito no mercado e que este não é autossuficiente, ao contrário, é falho, a tributação passa a ter um papel importante e diferenciado na manutenção de um mercado eficiente. Nesse sentido, algumas falhas de mercado pressupõem a imposição de intervenções do Estado sobre o domínio econômico, com o intuito de buscar a afetação ótima de recursos, obter taxas maiores de crescimento ou mesmo a própria estabilidade econômica. ${ }^{25}$

Segundo Ary Brandão de Oliveira $^{26}$, em qualquer sistema de economia capitalista atual, o Poder Público faz-se presente. A "mão invisível" de Adam Smith transformou-se na "mão pública", em intervenção do Estado no jogo econômico. A intervenção estatal sobre o domínio econômico torna-se, então, não uma medida excepcional, mas, sim, uma medida ordinária, a fim de ordenar, guiar e até mesmo corrigir o mercado.

Nesse contexto, a neutralidade passa a ter uma interpretação diferente, passa-se a interpretar a neutralidade no sentido de se preservar a igualdade e a liberdade no próprio mercado. Em outras palavras, podemos dizer que a neutralidade tributária, na atualidade, visa, essencialmente, a preservar a própria livre concorrência, de modo que voltaremos a tratar deste tema especificamente mais adiante.

Apesar de somente há pouco tempo o tema da extrafiscalidade ter chamado a atenção dos estudiosos do Direito, ao menos para maiores análises científicas, Alberto Deodato $^{27}$ exemplifica a antiguidade da percepção de que o tributo exerce uma função

${ }^{24}$ SANTOS, António Carlos. Auxílios de Estado e fiscalidade. Coimbra, 2003, p. 355.

${ }^{25}$ Ibidem, p. 360.

${ }^{26}$ OLIVEIRA, Ary Brandão. Direitos sociais vs desenvolvimento nacional. In SCAFF, Fernando Facury. (coord.), Ordem econômica e social: estudos em homenagem a Ary Brandão de Oliveira. São Paulo: LTr, 1999 , p. 102.

27 DEODATO, Alberto. As funções extrafiscais do imposto. Tese apresentada à Faculdade de Direito da Universidade de Minas Gerais para o concurso de Professor Catedrático de Ciência das Finanças, 1949, p. 14. Segue o trecho citado pelo autor: " Quando em um Estado todos os indivíduos pertencem à mesma nação como cidadãos e cada qual possui por seu domínio o que um príncipe possui por seu império, podem-se aplicar impostos sobre as pessoas, sobre as terras ou sôbre as mercadorias, sôbre duas destas cousas ou sôbre o conjunto das três. No imposto sôbre as pessoas, seria uma porção dos bens. Em Atenas se haviam dividido os cidadãos em quatro classes: os que obtinham de seus bens cinco medidas de frutos líquidos ou secos, pagando como tributo um talento; os que logravam uma renda de trezentas medidas, que deviam abonar meio talento; os que tinham duzentas medidas, que pagavam somente dez minas; e os da quarta classe, que não pagavam nada. A taxa era justa, ainda que não fosse proporcional; não se contemplava a proporção de bens, mas a proporção das necessidades. Julgava-se que cada pessoa tinha uma necessidade física igual e que esta necessidade física não podia ser taxada; enquanto que o simplesmente útil tinha um correspondente taxável e, sem mais razão, o supérfluo. O gravame sobre o supérfluo podia chegar a impedir o seu uso ou emprego." E 
social e econômica, citando uma passagem do livro de Montesquieu, Cap. III, de $O$ Espírito das Leis, de 1748.

Luís Eduardo Schoueri, afirma que, já no Império Romano, havia normas tributárias que visavam ao efeito da indução comportamental. O autor dá o exemplo de um imposto sobre as obras de arte gregas e o luxo das mulheres, criado com o intuito de diminuir a influência helênica em Roma. ${ }^{28}$

Porém, somente há cerca de setenta anos, durante os períodos dos pós-guerras, principalmente após a Segunda Grande Guerra, é que houve um incremento na utilização da intervenção econômica, por meio de normas tributárias indutoras. Naquele dado momento histórico, a Europa, arrasada pela guerra, precisava voltar a desenvolver-se e de recursos para a sua reconstrução. ${ }^{29}$ Em tal contexto, Ruy Barbosa Nogueira trata do assunto de forma um pouco mais ampla e assevera, que a partir da metade do século XX, há uma transformação nas funções e nos deveres do Estado com uma crescente e constante intervenção do poder público em quase todos os setores da atividade dos particulares, mas principalmente na esfera econômica. ${ }^{30}$

Podemos afirmar, então, que a tributação sempre fora vista como um simples instrumento ou meio de arrecadação de recursos para que o Estado pudesse desenvolver as suas mais variadas funções. Essas funções estatais constituem, em essência, a razão última da própria existência do Estado. No entanto, atualmente, é certo que esta instrumentalidade continua válida, mas não se restringe à obtenção de ingresso de recursos e, posteriormente, como consequência, à sua efetiva despesa, isto é, não se resume ao binômio ingresso-gasto. A tributação presta-se, também, à consecução de outros fins igualmente amparados pela Constituição, mas que não se moldam na simples arrecadação de recursos, pelo menos não prioritariamente. Há, portanto, uma alteração no binômio ingresso-gasto. ${ }^{31}$ A tributação passa a ter outros objetivos, deixa de ser um instrumento exclusivo de arrecadação, para tornar-se um instrumento de efetivação de políticas públicas.

Oportuno, então, verificarmos as ideias básicas sobre os conceitos de tributação fiscal e tributação extrafiscal. Nesse sentido, segundo as lições de Klaus Tipke, as normas tributárias podem ser distinguidas em três grupos, conforme a sua finalidade: a)

conclui Deodato: "Foi o pensamento liberal que deu lugar às profundas controvérsias sobre uma tese tão evidente: o imposto nunca pode ser neutro."

28 SCHOUERI, Luís Eduardo. Normas tributárias indutoras e intervenção econômica. Rio de Janeiro: Forense, 2005, p. 109.

${ }^{29}$ Ibidem, p. 114.

${ }^{30}$ NOGUEIRA, Ruy Barbosa. Curso de direito tributário. 15a ed., São Paulo: Saraiva, 1999, p. 184.

${ }^{31}$ GONZÁLEZ, Luis Manuel Alonso. Los impuestos autonomicos de caracter extrafiscal. Madrid: Marcial Pons, 1995, p. 12. 
normas de finalidade fiscal; b) normas de finalidade simplificadora; e c) normas de finalidade social. ${ }^{32}$ Importante destacar, desde já, que o autor faz uma advertência expressa para a possibilidade de a norma tributária poder perseguir mais de uma dessas finalidades.

As normas de finalidade fiscal são as entendidas no sentido clássico do termo tributo, isto é, prestam-se a gerar o ingresso de recursos aos cofres estatais e a cobrir as necessidades financeiras do orçamento público e devem, obrigatoriamente, observar o princípio da capacidade contributiva. Ainda com base em Tipke, as normas de finalidade fiscal causam repercussões econômicas e sociais. No entanto, não se trata de uma finalidade primária e, sim, de "efeitos colaterais". São consequências e não objetivos a serem alcançados por esse grupo de normas. ${ }^{33}$

As normas de finalidade simplificadora, como o próprio nome já induz, são normas que visam a facilitar a aplicação das normas tributárias. Essa simplificação é almejada por motivos técnico-econômicos, e visa a dar uma configuração mais prática e econômica, com o escopo de evitar a excessiva complexidade e inexequibilidade da lei tributária. $^{34}$

Normas de finalidade social não possuem uma motivação fiscal. São normas direcionantes, reguladoras, intervencionistas, que visam a políticas sociais, econômicas, culturais, sanitárias, profissionais ou a outras espécies de políticas e visam a promover o interesse público, o bem comum dos cidadãos. ${ }^{35}$

Nesse contexto, as normas de finalidade social não pertencem, no que diz respeito à sua materialidade, ao Direito Tributário, mas, sim, ao Direito Econômico, Social ou demais ramos do Direito. ${ }^{36}$ Em regra, são normas que se servem da técnica das leis tributárias, da instrumentalidade do Direito Tributário, mas que materialmente pertencem a outros ramos do Direito.

Casalta Nabais compartilha do mesmo entendimento e assevera que a extrafiscalidade se traduz em normas que, apesar de formalmente integrarem o direito fiscal, têm por finalidade principal, ou dominante, a consecução de determinados resultados econômicos ou sociais. A tributação seria apenas o meio, o instrumento, do qual

\footnotetext{
${ }^{32}$ TIPKE, Klaus. Direito Tributário.Tradução da $18^{\mathrm{a}}$ ed. Alemã, totalmente refeita, de Luiz Doria Furquim, Porto Alegre: Sergio Antonio Fabris Ed., 2008, p. 175.

${ }^{33}$ Ibidem, p. 175.

${ }^{34}$ Ibidem, p. 178.

${ }^{35}$ Ibidem, p. 176.

${ }^{36}$ Ibidem, p. 177.
} 
o Estado se utiliza, embora sua utilização não vise à obtenção de receitas para fazer face às despesas públicas. ${ }^{37}$

Vejamos, então, quais as formas de que o Estado dispõe para intervir na economia.

\subsection{FORMAS DE INTERVENÇÃO ECONÔMICA}

Primeiramente, convém fazermos alguns breves comentários acerca da expressão intervenção econômica. De plano, é importante afastar a ideia de que o Estado estaria agindo em uma área que não lhe é própria, ou seja, que estaria "interferindo" em no que não lhe diz respeito. Ao contrário, Estado e economia sempre andaram juntos, ao menos, para organizar o sistema econômico existente. ${ }^{38}$

Segundo Raimundo Bezerra Falcão, durante o Estado Liberal, o mercado livre, a livre concorrência e seus consectários eram tão relevantes para o Estado, que, por uma decisão política consciente, o próprio Estado optou por não interferir, numa espécie de intervenção por omissão, sob o argumento da total liberdade. Com a mudança de posição do Estado e o advento do "intervencionismo" estatal, supera-se a fase de ausência estatal e surge uma fase em que a presença do Estado é bem nítida. ${ }^{39}$

Dentre os vários critérios e as várias classificações existentes em relação às formas de intervenção do Estado na economia, optamos pela feita por Eros Roberto Grau ${ }^{40}$, porque, apesar das várias classificações existentes, fatalmente, elas findam por refletir os dois grandes critérios utilizados por Eros Grau, "intervenção sobre o domínio econômico" ou "intervenção no domínio econômico".

Conforme o citado autor, a intervenção no domínio econômico ocorre quando o Estado atua como um verdadeiro agente econômico, ou um player do mercado. Esse tipo de intervenção pode ser feito de duas maneiras: a) por absorção; ou b) participação. $^{41}$

\footnotetext{
37 NABAIS, José Casalta. O dever fundamental de pagar impostos: contributo para a compreensão constitucional do estado fiscal. Coimbra: Edições Almedina SA, 2009, p. 629.

${ }^{38}$ SCAFF, Fernando Facury. Responsabilidade do Estado intervencionista, cit., p. 37.

${ }^{39}$ FALCÃO, Raimundo Bezerra. Direito Econômico (Teoria Fundamental), cit., p. 110-111.

${ }^{40}$ GRAU, Eros Roberto. A ordem econômica na Constituição de 1988, interpretação e crítica. $13^{\mathrm{a}}$ ed., São Paulo: Malheiros Editores, 2008.

${ }^{41}$ Ibidem, p. 147.
} 
Quando a intervenção é por absorção, o Estado decide assumir integralmente o controle dos meios de produção de um dado segmento econômico e não permite o desenvolvimento daquela atividade por outro agente. O Estado absorve todo o segmento e atua em regime de monopólio.

Já na intervenção por participação, o Estado decide assumir apenas uma parte de um determinado segmento econômico e permite que outros agentes atuem com ele. Assim, não haverá monopólio, mas, sim, competição, concorrência.

$\mathrm{Na}$ intervenção sobre o domínio econômico, o Estado atua como o regulador dessa atividade ${ }^{42}$ e edita normas com o intuito de ordenar, organizar determinado setor econômico, mas sem a sua participação direta como agente. Vale ressaltar aqui as considerações feitas por Scaff, que, ao tratar do assunto, afirma que este tipo de elaboração normativa não se restringe à atividade legislativa, por ser mais abrangente. Engloba os três poderes, Executivo, Legislativo e Judiciário. Assim, o Estado pode agir mediante leis, portarias, regulamentos, decretos-leis, regimentos e outros, abrangendo, nessa concepção, toda e qualquer forma de expressão do poder normativo. ${ }^{43}$ Quando assim agir, o Estado poderá editar normas: a) de direção; ou b) de indução.

Ao editar normas de direção, o Estado impõe determinado comportamento, faz com que não seja permitido outro tipo de conduta, senão aquele estabelecido na norma. Trata-se de medida compulsória e a sua não observação faz surgir uma sanção jurídica. Exemplo típico é o tabelamento ou congelamento de preços.

Já nas normas de indução, o Estado não impõe comportamento algum, apenas privilegia ou desfavorece determinado comportamento, e faz com que este ou aquele comportamento seja economicamente mais vantajoso ou oneroso. Em um sentido mais amplo, é o que se convencionou chamar de extrafiscalidade ou normas tributárias indutoras, ou mesmo normas de finalidade social.

A tributação ambiental insere-se, precisamente, nesse contexto, isto é, o Estado utiliza-se do aparelho fiscal, do instrumento tributo, para alcançar um fim socialmente desejado, consistente na preservação, manutenção ou recuperação do ambiente ecológico. Segundo Juan Alabern, atualmente, é impensável realizar um estudo sério sobre a extrafiscalidade sem abordar o tema da tributação ecológica, uma vez que essa matéria tem

\footnotetext{
${ }^{42}$ Ibidem, p. 147.

${ }^{43}$ SCAFF, Fernando Facury. Responsabilidade do Estado Intervencionista, cit., p. 47.
} 
ocupado especial protagonismo nos últimos anos e, com o passar do tempo, a relevância do tema só tem aumentado. ${ }^{44}$

Assim, vamos dar ênfase à análise da intervenção estatal por indução e não nas demais espécies citadas acima.

\subsubsection{Intervenção por indução}

Ressalte-se, desde logo, que no campo da indução, o Estado não impõe tipo algum de comportamento. Ele tenta fazer com que o próprio agente econômico opte por seguir aquele caminho, que o Estado entende como desejado, seja estimulando o caminho a ser seguido, seja desestimulando o caminho a não ser seguido.

Eros Grau, ao tratar especificamente das normas de intervenção por indução, afirma que o Estado faz uma verdadeira sedução pela adoção do comportamento editado na norma e os agentes econômicos que optarem por não adotar tal comportamento acabam por ocupar uma posição desprivilegiada no mercado, enquanto os concorrentes que optaram pelo comportamento descrito na norma despontam com melhores condições de concorrer naquele mesmo mercado, já que possuem algum tipo de isenção ou redução de tributo. ${ }^{45}$ Nesse sentido, é bastante elucidativa a afirmação de Schoueri, ao asseverar que um ponto relevante da intervenção por indução é que ela não afasta o mercado, mas ao contrário, pressupõe-no. $^{46}$

Normas tributárias indutoras, portanto, são normas que, apesar de serem normas formalmente tributárias, não têm como finalidade precípua a arrecadação dos recursos necessários ao custeio da despesa pública, mas, preponderantemente, a promoção pelo Estado de outros fins de políticas públicas, tais como a política social, econômica, cultural, sanitária, ambiental, inclusive a redistribuição de renda, dentre outras. ${ }^{47}$

Para José Marcos Domingues de Oliveira, na tributação extrafiscal, estão inseridos outros fins que não sejam a captação de dinheiro para o Erário, tais como a redistribuição de renda e terra, a defesa da indústria nacional, a orientação dos

${ }^{44}$ ALABERN, Juan Enrique Varona. Extrafiscalidad y dogmática tributaria. Madrid: Marcial Pons, 2009, p. 12.

${ }^{45}$ GRAU, Eros Roberto. op. cit., A Ordem econômica..., p. 149.

${ }^{46}$ SCHOUERI, Luís Eduardo. op. cit, Normas tributárias..., p. 44.

${ }^{47}$ ROTHMANN, Gerd Willi. Tributação, sonegação e livre concorrência. In FERRAZ, Roberto Catalano Botelho (coord.), Princípios e limites da tributação 2 - Os princípios da Ordem Econômica e a Tributação. São Paulo: Quartier Latin, 2009, p. 338. 
investimentos para setores produtivos ou mais adequados ao interesse público, a promoção do desenvolvimento regional ou setorial e outros. ${ }^{48}$

Schoueri, ao defender o uso da expressão normas tributárias indutoras, destaca que a referida expressão tem como finalidade precípua não deixar dúvida de que, embora se trate de instrumento a serviço do Estado na intervenção por indução, tais normas não perdem a característica de serem, ao mesmo tempo, relativas a tributos e, precisamente por esse motivo, se sujeitarem aos princípios e regras próprias do campo tributário. ${ }^{49}$

Da mesma forma como não há mais que se falar em tributo que não exerça algum tipo de influência sobre o comportamento do agente econômico, ou seja, não há mais que se falar naquela ideia de neutralidade tributária como defendida pelos adeptos do liberalismo econômico. Igualmente, não há que se falar em um tributo exclusivamente fiscal ou exclusivamente extrafiscal. A ideia central, nesse contexto, deve ser a da preponderância, uma vez que todo tributo fiscal irá exercer algum tipo de efeito extrafiscal, e todo tributo extrafiscal terá algum efeito fiscal. Portanto, como adverte Tipke, existem tributos que, substancialmente, têm uma finalidade dirigista, mas nem por isso se pode falar em ausência de fiscalidade, pois, se fossem destituídos de toda fiscalidade acessória, não seriam, então, em absoluto tributos. ${ }^{50}$

Perfecto Martul-Ortega, ao dissertar sobre os fins extrafiscais do imposto, assevera que, quando se fala de intervencionismo, normalmente se faz referência ao âmbito econômico e que o Estado utiliza os impostos para intervir na economia privada. Porém, com os impostos se podem alcançar outras metas não estritamente econômicas, tais como as políticas, sociais, culturais e outras. Assim, apesar do uso do termo intervenção econômica, não se pode esquecer essas outras possibilidades. ${ }^{51}$

Ainda segundo as ideias do citado autor, o imposto com fim não financeiro manifesta-se como medida de ordenação econômica e social, mas, junto a estas finalidades, podem aparecer outras, tais como demográficas, culturais com as quais o Estado influencia na liberdade dos particulares e na necessidade de intervir em certos consumos considerados prejudiciais para a conduta humana: tabaco, álcool, gasolina etc. ${ }^{52}$ Percebe-

\footnotetext{
${ }^{48}$ OLIVEIRA, José Marcos Domingues de. Direito tributário e meio ambiente. $3^{\mathrm{a}}$ ed., Rio de Janeiro: Forense, 2007, p. 47.

${ }^{49}$ SCHOUERI, Luís Eduardo. Ob. cit., Normas tributárias..., p. 34.

${ }^{50}$ TIPKE, Klaus. Moral tributária do estado e dos contribuintes. Tradução de Luiz Dória Furquim. Porto Alegre: Sergio Antonio Fabris Ed., 2012, p. 62.

51 MARTUL-ORTEGA, Perfecto Yebra. Los fines extrafiscales del impuesto. In Tratado de Derecho Tributario, Tomo Primeiro, El Derecho Tributario y sus fuentes, dirigido por Andrea Amatucci, BogotáColombia: Editorial Temis S.A., 2001, p. 356. Grifo original.

52 Ibidem, p. 357.
} 
se, assim, que, para o autor espanhol, a tributação extrafiscal é considerada, também, como um meio de ordenação, ou de regulamentação, de comportamentos dos indivíduos.

Segundo Ruy Barbosa Nogueira, o poder de regular, também conhecido como "poder de polícia" (police power), seria o poder de promover o bem público pela limitação e regulação da liberdade, do interesse e da propriedade. ${ }^{53}$ Nesse sentido, o catedrático da Universidade de São Paulo compartilha da mesma linha de pensamento do autor espanhol e assevera que o tributo também é um instrumento do poder de regular. Para Nogueira, regular é estabelecer regras, dirigir, governar. Assim, por meio do tributo, tanto quanto se poderá fomentar uma atividade, se poderá restringi-la, mas essas funções deverão estar em harmonia, em paralelo com o poder de regular, pois não poderão prejudicar uma atividade lícita. ${ }^{54}$

Aliomar Balieeiro também compartilha do pensamento de que a tributação extrafiscal está vinculada ao poder de polícia, porém adverte que esse poder deve estar dentro da competência da pessoa de Direito Público, sendo tolerado caso vise à proteção à vida, segurança, liberdade, higiene, bem-estar e moralidade dos cidadãos. ${ }^{55}$

Se não há maiores discussões em relação aos objetivos que a extrafiscalidade busca atingir, tais como direitos sociais e regulação econômica, isso não se pode afirmar em relação à natureza jurídica, isto é, a extrafiscalidade, realmente decorre do poder de polícia do Estado?

Walter Barbosa Corrêa entende que não. O autor entende que o poder de polícia visa a uma regulamentação de caráter absoluto e que, caso tal regulação seja desobedecida, sujeita o infrator a uma sanção. Para Corrêa, o poder de tributação, ao contrário, faz nascer tributos com o fim: $a$ ) de obter rendimento (fim fiscal); ou $b$ ) regulamentar, em caráter relativo (fins extrafiscais), mediante o desestímulo produzido por alta alíquota, certas ações ou omissões. ${ }^{56}$

Nesse mesmo sentido, Leila Paiva afirma que o rol de interesses públicos protegido pelo exercício regular do poder de polícia não se confunde com aquele que pode ser protegido pelos tributos extrafiscais. ${ }^{57}$ Em relação aquele, a Administração não poderia

\footnotetext{
${ }^{53}$ NOGUEIRA, Ruy Barbosa. Curso de direito tributário. $15^{\mathrm{a}}$ ed., São Paulo: Saraiva, 1999, p. 181. Grifo original.

${ }^{54}$ Ibidem, p. 182.

55 BALEEIRO, Aliomar. Uma introdução à Ciência das Finanças. $18^{\mathrm{a}}$ ed., atualizada por Hugo de Brito Machado Segundo. Rio de Janeiro: Forense, 2012, p. 232.

${ }^{56}$ CORRÊA, Walter Barbosa. Contribuição ao estudo da extrafiscalidade. São Paulo: Bentivegna, 1964, p. 33.

${ }^{57}$ PAIVA, Leila. Disciplina jurídica da extrafiscalidade. Dissertação de Mestrado da Faculdade de Direito da USP. São Paulo, sem data, p. 28.
} 
dar alternativa ao particular, imporia um determinado comportamento e, caso tal comportamento fosse violado, surgiria a penalidade, visto que se trata de interesse público indisponível, como por exemplo, as condições de higiene e limpeza de estabelecimentos que fornecem alimentação, enquanto em relação à tributação extrafiscal, a origem seria o próprio poder de tributar e, nesse caso, não haveria que se falar em imposição de comportamentos, mas, sim, de mera faculdade, uma vez que o particular poderia ou não praticar a hipótese de incidência descrita na lei. ${ }^{58}$

Regis Fernandes de Oliveira, ao abordar o tema poder de polícia, afirma que o Estado disciplina comportamentos humanos, restringindo-os ou fazendo com que sejam exercidos nos limites do permitido pelo ordenamento jurídico, ${ }^{59}$ ou seja, adequando-os.

Segundo Alfredo Augusto Becker, o Estado, para estimular ou desestimular determinado fato social, tem dois caminhos a escolher: a) ou regra jurídica que declare ilícito aquele fato social; b) ou tributo extrafiscal "proibitivo". ${ }^{60}$ Importante ressaltar que, com o termo tributo extrafiscal "proibitivo”, Becker não defendia o uso da tributação para impedir, efetivamente, qualquer tipo de atividade econômica, mas utilizava o termo "proibitivo" como sinônimo de desestimulante. ${ }^{61}$

Sendo assim, parece-nos que Schoueri ${ }^{62}$ foi muito feliz ao defender a expressão normas tributárias indutoras, porque a questão pode ser resolvida por esse caminho, isto é, a tributação extrafiscal, por ser norma tributária, continua tendo de submeter-se aos princípios e regras próprios do poder tributário.

Portanto, o Estado tem o poder e o dever de regular e ordenar o comportamento dos particulares e, ao fazê-lo, em algumas ocasiões, pode optar por tornar aquele comportamento ilícito ou permitido. Por si só, a regulamentação ou ordenação de comportamento dos particulares está incluída no poder de polícia do Estado. No entanto, ao permitir determinada conduta, o Estado pode optar por estimular ou desestimular tal comportamento e, para isso, ele possui inúmeros instrumentos, de modo que a tributação é apenas um deles.

Sendo assim, ao se utilizar da tributação extrafiscal, o Estado está, tão somente, utilizando um dos instrumentos dos quais dispõe para incentivar ou desestimular

\footnotetext{
${ }^{58}$ Ibidem, p. 27.

${ }^{59}$ OLIVEIRA, Regis Fernandes. Curso de direito financeiro. $5^{\mathrm{a}}$ ed., São Paulo: Revista dos Tribunais, 2013, p. 67.

${ }^{60}$ BECKER, Alfredo Augusto. Teoria geral do direito tributário. 4a ed., São Paulo: Noeses, 2007, p. 628. Grifos originais.

${ }^{61}$ Ibidem, p. 643.

${ }^{62}$ SCHOUERI, Luís Eduardo. Ob. cit., Normas tributárias..., p. 34.
} 
determinada conduta permitida. Escolhido o instrumento, meio, o recurso chamado tributo extrafiscal, continua a ter um ordenamento próprio, ou seja, continua tendo de atender aos princípios e regras da ordem tributária.

\title{
1.1.2 Indução tributária e tributação do ilícito
}

Diante das considerações feitas acima, é de extrema relevância a diferenciação entre tributação indutora e tributação do ilícito, em especial, para os propósitos deste trabalho. Apesar de não pretendermos ingressar na intrincada questão da possibilidade ou não de se tributar o ato ilícito, faz-se necessário traçarmos alguns breves comentários. Mas, de plano, há que se enfatizar que tais institutos não se confundem.

O conceito de tributo, insculpido no art. $3 .^{\circ}$ do CTN, é claro, ao dispor que:

\begin{abstract}
"Art. 3. - Tributo é toda prestação pecuniária compulsória, em moeda ou cujo valor nela se possa exprimir, que não constitua sanção de ato ilícito, instituída em lei e cobrada mediante atividade administrativa plenamente vinculada. (grifei).”
\end{abstract}

Pelo simples dispositivo legal mencionado, já poderíamos encerrar a questão, uma vez que o próprio ordenamento jurídico dispõe que tributo não se confunde com sanção por ato ilícito. É certo que, de todo ato ilícito, advém uma sanção e esta sanção pode ser pecuniária, como as multas. Porém, os tributos extrafiscais incidem sobre atividades lícitas, permitidas, mas indesejadas em certos níveis e, exatamente por isso, desestimuladas.

Multa não se confunde com tributação mais gravosa. A tributação mais gravosa tem o nítido intuito de desestimular, diminuir comportamentos permitidos, não inviabilizar, ou proibir por completo determinados comportamentos. Ora, se determinado comportamento é tão danoso que o Poder Público entende que ele não deva ser executado, o caminho a ser seguido é a proibição e não o desestímulo. O desestímulo a determinado comportamento só serve para comportamentos aceitáveis, mas indesejados a partir de certos índices. Nesse sentido, Carlos Palao Taboada, tratando especificamente da tributação ambiental, afirma que, se uma conduta é tão danosa a meio ambiente ao ponto de querer eliminar tal atividade, não se deve estabelecer um tributo tão elevado que ninguém realize o fato gerador, mas, sim, uma proibição acompanhada de sanções. ${ }^{63}$

63 Afirmação feita no prefácio da obra de: MOLINA, Pedro M. Herrera. Derecho tributario ambiental, introcucción del interes ambiental en el ordenamento tributario. Madrid: Marcial Pons, Ediciones Jurídicas y Sociales, S.A., 2000, p.24. 
Mizabel Derzi, atualizando a obra de Aliomar Baleeiro, faz uma nota acerca do assunto muito elucidativa. A autora aborda uma série de dispositivos penais, Código Penal, Código de Processo Penal e, especificamente, a Lei 9.613 de 03/03/ 1998 - Lei de Lavagem de Dinheiro, para afirmar que tributação e ilicitude são alternativas excludentes, ou a origem dos recursos é lícita, cobrando-se, em consequência, o tributo devido e sonegado, por meio da execução fiscal, ou é ilícita, sendo cabível o perdimento dos bens e recursos, fruto da infração. ${ }^{64}$

Segundo José Marcos Domingues de Oliveira, a extrafiscalidade permite ao contribuinte alternativa de escolha de gravame mais ameno, ou até mesmo de nenhum gravame, conforme o comportamento se desenvolva em um ou outro sentido, previsto em lei. ${ }^{65}$ Portanto, aponta o autor, a tributação extrafiscal não se destina a punir ilicitudes. Pretende-se orientar o agente econômico a planejar a sua atividade lícita, em conformidade com uma política pública legitimada pela Constituição. ${ }^{66}$

Apenas para citar alguns exemplos emblemáticos de uso irrestrito e posterior proibição, ou severa limitação no uso de materiais nocivos à saúde humana, temos a proibição do uso do chumbo em tintas e pigmentos, Lei 11.762/2008, a proibição do uso industrial de embalagens metálicas soldadas com liga de chumbo e estanho para acondicionamento de gêneros alimentícios, Lei 9.832/1999, e a severa restrição do uso de amianto, Lei 9.055/1995.

Dessa forma, o comportamento que vai ser tributado ou proibido, vai depender, exclusivamente, do próprio Poder Público. Portanto, trata-se de graus de reprovabilidade, pois ambas as condutas são indesejadas, mas apenas aquela vista com um grau maior de reprovabilidade é que vai ser entendida como ilícita, enquanto a de menor grau de reprovabilidade, ou aceitável até certo ponto, ou pode ser desestimulada por meio da extrafiscalidade, uma vez que continua a ser um comportamento lícito.

\footnotetext{
${ }^{64}$ BALEEIRO, Aliomar. Direito tributário brasileiro. $11^{\mathrm{a}}$ ed., atualizada por Mizabel Abreu Machado Derzi. Rio de Janeiro: Forense, 2009, p. 715-716, (NOTA). Importante ressaltar aqui que a citada Lei contra a Lavagem de Dinheiro foi alterada pela Lei 12. 683/2012.

${ }^{65}$ OLIVEIRA, José Marcos Domingues de. Direito tributário e meio ambiente. $3^{\mathrm{a}}$ ed., Rio de Janeiro: Forense, 2007, p. 48- 49.

${ }^{66}$ Ibidem, p. 50.
} 


\subsection{DESENVOLVIMENTO ECONÔMICO}

É importante, desde já, esclarecermos que, neste tópico, não pretendemos traçar um conceito ou um significado detalhado do que é desenvolvimento econômico, nem para os economistas tampouco para os juristas. Pretendemos, apenas, fixar algumas breves ideias da sua evolução, a fim de que consigamos entender como o desenvolvimento econômico está inserido na questão ecológica e na da tributação ambiental.

Celso Furtado já alertava para os problemas do desenvolvimento econômico e da degradação ambiental desde a década de setenta do século passado. O autor afirmava que os ritmos dos processos de civilização e de industrialização, particularmente o formado a partir da Revolução Industrial, e a criação de valor econômico provocam, em um grande número de casos, processos irreversíveis de degradação do mundo físico, que o homem faz questão de ignorar. ${ }^{67} 68$

O art. 3. ${ }^{\circ}$ da Constituição Federal de 1988, ao tratar dos objetivos fundamentais da República, estabelece, em seu inciso II, a garantia do desenvolvimento nacional.

\footnotetext{
“Art $3 .^{\circ}$ - Constituem objetivos fundamentais da República Federativa do Brasil:

(...)

II - garantir o desenvolvimento nacional;"
}

Apenas pela leitura desse dispositivo já podemos chegar à conclusão de que o constituinte originário elencou como objetivo fundamental da República brasileira não o simples desenvolvimento econômico, tido como sinônimo de crescimento econômico, mas, sim, o desenvolvimento nacional. Isso significa que este é bem mais amplo e abrangente que aquele e que o citado objetivo fundamental não visa apenas ao crescimento econômico, mas, sobretudo, ao desenvolvimento de toda a nação brasileira, porque, como afirma

\footnotetext{
${ }^{67}$ FURTADO, Celso. O mito do desenvolvimento econômico. São Paulo: Círculo do Livro S.A., sem data, p. 17.

${ }^{68} \mathrm{O}$ estudo feito por Celso Furtado foi elaborado no mesmo período em que ocorreu a Conferência Mundial sobre o Meio Ambiente Humano, organizado pela ONU, em Estocolmo - Suécia, em 1972. Nessa Conferência foi apresentado o famoso estudo do Clube de Roma, The Limits to growth. Esse estudo previa, resumidamente, que, se os padrões de desenvolvimento econômico se mantivessem os mesmos, e se todos os povos da Terra atingissem tais padrões, o Planeta simplesmente não suportaria. Pois, os recursos não renováveis seriam insuficientes e a poluição do meio ambiente seria tão grande, ou com um custo tão elevado para eliminá-la, que o sistema econômico mundial entraria em colapso.
} 
Raimundo Bezerra Falcão, crescimento econômico é um conceito bem mais restrito e pobre do que o de desenvolvimento. ${ }^{69}$

Sendo assim, é importante destacarmos que crescimento econômico e desenvolvimento econômico não se confundem. A ideia de que crescimento econômico seria sinônimo de desenvolvimento econômico é um pensamento ultrapassado, típico dos séculos passados, notadamente o século XIX e meados do século XX. O pensamento de Irma Adelman ilustra bem esse ponto de vista. Para a autora, desenvolvimento econômico seria o processo pelo qual uma economia que tivesse uma taxa de crescimento da renda per capita pequena ou negativa seria transformada numa economia que tivesse como característica permanente de longo prazo uma taxa significativa de crescimento autossustentado da renda per capita. ${ }^{70}$ Percebe-se, portanto, que Adelman conceitua desenvolvimento econômico como sinônimo do simples crescimento da taxa de renda per capita.

Em sentido oposto e mais condizente com a atual realidade em que vivemos, Amartya Sen entende que o desenvolvimento é muito maior do que a acumulação de riqueza e do crescimento do Produto Nacional Bruto (PNB) e de outras variáveis, simplesmente relacionadas à renda. Afirma, inda, que é inadequado adotar como objetivo básico, tão somente, a maximização da renda ou da riqueza. O desenvolvimento deve estar relacionado, sobretudo, com a melhora da vida que se leva e das liberdades desfrutadas. ${ }^{71}$

Importante destacar que o referido autor não diz que o crescimento do PNB, o aumento de rendas pessoais, a industrialização, o avanço tecnológico ou a modernização social são dispensáveis, apenas enfatiza que tais situações não são por si sós, suficientes. Para Sen, tais situações podem ser um meio para a expansão das liberdades dos membros da sociedade, mas também dependem de outros fatores, tais como disposições sociais e econômicas, e.g. serviços de educação e saúde e direitos civis. ${ }^{72}$

Gilberto Bercovici percorre uma linha de pensamento semelhante, ao enfatizar que crescimento sem transformação social é simples modernização e esta apenas agrava a concentração de renda. Para o autor, quando não ocorre transformação, seja social, seja no sistema produtivo, não se está diante de um processo de desenvolvimento, mas, sim, de

${ }^{69}$ FALCÃO, Raimundo Bezerra. Direito econômico (teoria fundamental). São Paulo: Malheiros Editores, 2013 , p. 95.

${ }^{70}$ ADELMAN, Irma. Teorias do desenvolvimento econômico. Tradução de Denise Cabral C. de Oliveira. Rio de Janeiro: Forense, 1972, p. 1.

${ }^{71}$ SEN, Amartya. Desenvolvimento como liberdade. Tradução de Laura Teixeira Motta; revisão técnica Ricardo Doniselli Mendes. São Paulo: Companhia das Letras, 2000, p. 28-29.

${ }^{72}$ Ibidem, p. 17. 
simples modernização. Com a modernização, mantém-se o subdesenvolvimento, agrava-se a concentração de renda e não se contribui para melhorar as condições de vida da maioria da população. ${ }^{73}$

Raimundo Bezerra Falcão é enfático ao asseverar que desenvolvimento não é apenas crescimento econômico ou simples produção de riqueza. Desenvolvimento pressupõe distribuição ou redistribuição da riqueza, em favor do bem-estar social. ${ }^{74}$

Dessa forma, parece-nos nítido que a ideia de desenvolvimento nacional, elencada como um dos objetivos fundamentais da República, não está adstrita ao simples crescimento econômico do País. O desenvolvimento nacional passa, necessariamente, por avanços nas questões dos direitos sociais.

Em relação aos direitos sociais, mais especificamente no que tange aos custos desses direitos, Raimundo Bezerra Falcão faz um alerta importante, visto que a preocupação com o custo social do desenvolvimento não pode deixar de ser levada em consideração, sob pena de descaracterização do próprio processo de desenvolvimento, uma vez que o viés social é um dos principais pontos do conceito de desenvolvimento. ${ }^{75}$

\subsubsection{Desenvolvimento e meio ambiente}

A relação do meio ambiente com o desenvolvimento econômico é facilmente verificada de uma simples constatação, observada por Cristiane Derani, mediante a qual o fator natureza, ao lado do fator trabalho e do fator capital, compõe a tríade fundamental para o desenvolvimento da atividade econômica. ${ }^{76}$

Assim, em essência, toda economia depende de algum tipo de elemento natural, de algum tipo de matéria-prima, que pode ser transformada em outro produto ou não, isto é, tal bem natural pode ser consumido in natura, tais como os produtos agrícolas, os legumes, os vegetais, as frutas; ou o bem natural pode ser transformado em outro produto, os produtos industrializados, tais como os derivados do petróleo, que dão origem a combustíveis, plásticos e a uma infinidade de subprodutos; os derivados de minérios, como ferro, que dão origem ao aço, ferro fundido, entre outros.

\footnotetext{
${ }^{73}$ BERCOVICI, Gilberto. Constituição econômica e desenvolvimento, uma leitura a partir da Constituição de 1988. São Paulo: Malheiros Editores, 2005, p. 53.

${ }_{75}^{74}$ FALCÃO, Raimundo Bezerra. Op. Cit. p. 91.

${ }^{75}$ Ibidem, p. 93.

${ }^{76}$ DERANI, Cristiane. Ob. cit., (nota 1) da Introdução, p. 21.
} 
Quando se trata de matéria-prima, é importante ter em mente, de forma automática, que estamos diante de produtos escassos, finitos. Exatamente aí está o cerne dos estudos econômicos, isto é, como se dá a interação entre oferta e demanda de produtos escassos. Exatamente por isso, é fundamental que o homem entenda, em definitivo, como alerta Lafayete Petter, que a exploração econômica há de ser realizada dentro dos limites de capacidade dos respectivos ecossistemas. ${ }^{77}$

Joan Alier e Jordi Jusmet, ao abordarem o tema da evolução do conceito de economia, afirmam que a economia ecológica abarca a economia neoclássica e transcendea, já que aquela também inclui a avaliação física dos impactos ambientais da economia humana. ${ }^{78}$ Portanto, atualmente, não se pode mais analisar, apenas, a oferta e a demanda de determinado produto com base nas suas reservas, isto é, quantificar o bem com base na sua escassez.

Nesse contexto a noção de sustentabilidade vem ganhando mais força, apesar de ainda não haver uma unidade de pensamento a respeito de seu conceito. Maria de Fátima Ribeiro e Jussara Ferreira afirmam que para existir desenvolvimento sustentável, são necessárias três situações: crescimento econômico, qualidade de vida e justiça social. No entanto, especificamente em relação ao crescimento econômico, citando Vânia Kirzner, as autoras complementam o raciocínio, ao afirmarem que é necessário procurar alternativas e formas de crescimento econômico que não sejam degradadoras do meio ambiente, e não sejam impactantes. Mas, caso sejam, devem ser procuradas fórmulas a fim de neutralizarem os seus efeitos nocivos, com o intuito de que o crescimento econômico continue proporcionando qualidade de vida e justiça social. ${ }^{79}$

Lafayete Petter não tenta dar um conceito de sustentabilidade, mas, ao tratar do assunto, também faz referência à justiça social e ao equilíbrio ambiental. Afirma que o modelo econômico predatório do século XX precisa ceder espaço ao modelo econômico sustentável do século XXI, que, além da eficiência econômica, também toma em conta o equilíbrio ambiental e a justiça social. O progresso não pode ser confundido com a industrialização a qualquer custo, ou com a edificação irrestrita de bens materiais. ${ }^{80}$

\footnotetext{
${ }^{77}$ PETTER, Lafayete Josué. Princípios constitucionais da ordem econômica: o significado e o alcance do art. 170 da Constituição Federal. $2^{\mathrm{a}}$ ed., São Paulo: Revista dos Tribunais, 2008, p. 273.

${ }^{78}$ MARTÍNEZ Alier, Joan y Jordi Roca Jusmet. Economía ecológica y política ambiental. México: FCE, 2001, p. 14.

${ }^{79}$ RIBEIRO, Maria de Fátima; e FERREIRA, Jussara S. Assis Borges Nasser. O papel do Estado no desenvolvimento econômico sustentável: reflexões sobre a tributação ambiental como instrumento de políticas públicas. In TÔRRES, Heleno Taveira (org.). Direito tributário ambiental. São Paulo: Malheiros Editores, 2005, p. 655.

${ }^{80}$ PETTER, Lafayete Josué. Op. cit., p. 287.
} 
Dessa forma, alguns elementos parecem ser constantes no que diz respeito à noção de sustentabilidade, os quais se assemelham muito à própria ideia da nova percepção de desenvolvimento econômico. A justiça social e a impossibilidade de um simples crescimento econômico são elementos intrínsecos ao desenvolvimento econômico e, pelo que se depreende, à própria sustentabilidade.

Assim, não por acaso, Juarez Freitas relembra-nos que, uma vez superado o ultrapassado índice para medição de desenvolvimento econômico, entenda-se aqui simples crescimento, Produto Interno Bruto - PIB, surgia o Índice de Desenvolvimento Humano IDH. Esse novo índice, que mede renda, longevidade e educação, representa considerável progresso. No entanto, um dos criadores desse índice, Amartya Sen, com Joseph Stiglitz e outros, entendendo que o índice estava ultrapassado, trabalham para reformular os indicadores do referido índice, o que gerou o relatório da Comissão Stiglitz-Sen-Fitoussi. Bem relevante, e que nos interessa de forma mais direta nesse relatório é que a sustentabilidade surge como um dos fatores a serem considerados na avaliação do desempenho econômico. ${ }^{81}$

José Afonso da Silva compartilha da mesma linha de raciocínio e afirma que o desenvolvimento econômico não pode ser definido apenas em termos de PNB (Produto Nacional Bruto) real por habitante ou de consumo real por habitante, uma vez que esse conceito deve ser alargado, a fim de incluir outros elementos, tais como a educação, a saúde, a qualidade do meio ambiente e, consequentemente, a qualidade de vida. ${ }^{82}$

Portanto, atualmente, não se pode mais analisar apenas a oferta e a demanda de determinado produto com base nas suas reservas, isto é, quantificar o bem com base na sua escassez. É preciso preocupar-se, também, com o respectivo impacto ecológico da extração daquele bem natural e com o impacto que o processo de produção ou transformação do bem irá gerar, porquanto esses impactos influenciam no próprio desenvolvimento econômico, além de poder influenciar na produção ou extração do próprio bem, ou de outros bens.

Posto isso, alguns agentes econômicos, ao desenvolverem suas atividades, acabam por gerar algum tipo de poluição ou custos que serão suportados por outros agentes econômicos, o que se convencionou chamar de externalidades negativas.

\footnotetext{
${ }^{81}$ FREITAS, Juarez. Ob. cit., segundo o autor, o citado relatório está disponível no sitio eletrônico: (www.stiglitz-sen-fitoussi.fr).

${ }^{82}$ SILVA, José Afonso da. Direito ambiental constitucional. $8^{a}$ ed., São Paulo: Malheiros Editores, 2010, p. 26.
} 


\subsubsection{Falhas de mercado}

É cediço que o mercado ${ }^{83}$, assim como outros institutos da economia e de outras ciências, tem uma compreensão de um funcionamento ideal, isto é, segundo a teoria, se existissem determinadas condições ideais, o mercado funcionaria, também, de forma ideal e resultaria em ganhos semelhantes para todas as partes envolvidas. Ocorre que, como modelo teórico ideal, dificilmente tais condições acontecem na prática.

A ideia de um mercado ideal ou de eficiência ideal pode ser sintetizada no pensamento de Pareto. Conforme as ideias desse teórico, uma dada conjuntura seria considerada ideal quando não houvesse uma forma de melhorar a situação de um indivíduo, sem piorar a situação de outro, pensamento que ficou conhecido como Ótimo de Pareto. $^{84}$

Com base neste pensamento, os Governos buscam a eficiência de seus mercados. No entanto, já vimos que os mercados não são autossuficientes. A ideia de que mão invisível guiaria, sozinha, os rumos do mercado até o seu funcionamento ideal, foi rechaçada e reprovada, principalmente em razão das comprovações práticas. Assim, as falhas de mercado, das quais as externalidades fazem parte, como o próprio nome já dá ensejo, são falhas, imperfeições ou inoperacionalidades do próprio mercado.

Fábio Nusdeo, ${ }^{85}$ tratando acerca do tema, leciona que, durante o liberalismo, em razão dos inúmeros desafios políticos que estavam postos naquele momento, os estudiosos econômicos passaram a submeter os mecanismos de funcionamento do mercado a inúmeras críticas. Tais críticos chegaram à conclusão de que o mercado era viável e operacional. No entanto, a referida operacionalidade dependeria de diversos pressupostos que a estrutura legal própria do liberalismo não havia conseguido captar, tampouco tratar. E, sem aqueles pressupostos, a mecânica operacional do sistema de mercado passava a operar de forma insatisfatória, produzia resultados também falhos e, em muitos casos, inaceitáveis.

\footnotetext{
${ }^{83}$ Fábio NUSDEO dá um conceito de mercado de forma bastante simples e didática, "no fundo, mercado vem a ser um conjunto de instituições a permitir aquela interação entre oferta e procura da qual surgirão de forma espontânea, impessoal e objetiva os preços de cada produto e de cada serviço. E esse preços eferíveis por todos os agentes econômicos - operadores do mercado - os levarão a decidir corretamente quanto ao uso dos mesmos bens e serviços, porque todos estão pautando aquelas decisões por um padrão ou diapasão comum: o hedonismo provindo deles próprios. " In Curso de economia: introdução ao direito econômico. $2^{\mathrm{a}}$ ed., São Paulo: Revista dos Tribunais, 2000, p. 115

${ }^{84}$ PARETO, Vilfredo. Manual de economia política. Tradução de João Guilherme Vargas Netto. Nova Cultural, 1996, p. 265 e segs.

${ }^{85}$ NUSDEO, Fábio, op. cit., p. 139.
} 
São cinco as principais falhas ${ }^{86}$, que corresponderiam àqueles pressupostos de funcionamento do mercado: $a$ ) mobilidade de fatores; $b$ ) acesso às informações relevantes; c) concentração econômica; $d$ ) bens públicos; e e) externalidades. As que mais nos interessam são as externalidades, assim, apenas iremos mencionar, brevemente, no que consiste cada uma das demais falhas.

A mobilidade dos fatores de produção e de seus agentes diz respeito à plena facilidade de acesso ou retirada do mercado por parte de qualquer interessado. Segundo Nusdeo, tal mobilidade seria necessária para permitir aos empresários-produtores responder de forma rápida e fiel às decisões soberanas do consumidor, os quais seriam informados por meio de sinais indicativos, representados pelos preços, como deveria reagir, a fim de reverter situações indesejadas. Entretanto, tal agilidade não ocorre na prática. Pelo contrário, normalmente, há rigidez de toda ordem: física, operacional, institucional, psicológica. ${ }^{87}$

$\mathrm{O}$ acesso às informações relevantes consiste na ideia de que todos os integrantes do mercado, compradores e vendedores, têm igual nível de informação sobre o mercado. ${ }^{88}$ Assim, irá ocorrer a falha quando um dos integrantes do mercado não tem acesso a determinada informação simultaneamente com os outros integrantes. Exemplo clássico de um problema de acesso às informações relevantes é o de uma construtora que trabalha com obras públicas, e os seus diretores e principais assessores ficam sabendo de um grande contrato que será celebrado pela empresa, por exemplo, a barragem de um grande rio. Esses integrantes do mercado poderão ir à Bolsa de Valores e adquirir várias ações a um preço baixo, com a certeza, em razão da informação privilegiada, de que as ações irão subir, ou mesmo o cenário de forma inversa. Tal situação é considerada crime em muitas legislações, caso não seja feita a devida comunicação no órgão competente e constitui a chamada informação privilegiada ou insider trading. ${ }^{89}$

A concentração econômica ou falha de estrutura ocorre quando não há a chamada atomização. Não existe naquele mercado um número equilibrado entre compradores e vendedores em interação recíproca, porque nenhum deles é muito grande ou muito pequeno. ${ }^{90}$ Essa falha afeta diretamente a concorrência entre os integrantes do

\footnotetext{
${ }^{86}$ Há alguns autores que incluem como uma sexta falha de mercado o desemprego, a inflação e o desequilíbrio. STIGLITZ, Joseph E., Economics of the public sector. $3^{\mathrm{a}}$ ed., New York: Norton \& Company, Inc., 2000, p. 77, 85 .

${ }^{87}$ Ibidem, p. 140.

${ }^{88}$ SCHOUERI, Luís Eduardo. Direito tributário. São Paulo: Saraiva, 2011, p. 35.

${ }^{89}$ NUSDEO, Fábio. Ob. cit., p. 145.

${ }^{90}$ Ibidem, p. 146.
} 
mercado, o que pode fazer com que sejam gerados oligopólios ou monopólios, em relação aos produtores, ou oligopsônio ou monopsônio, em relação aos compradores.

Os bens coletivos, ou falha de incentivo, estão ligados ao hedonismo dos agentes econômicos, isto é, os agentes não estão dispostos a pagar por um bem que também poderá ser usado por outro agente, mas sem que este segundo arque com um novo custo. Nesse sentido, economias fundadas exclusivamente no mercado tendem a discriminar fortemente os bens coletivos e a exagerar na produção de bens exclusivos. Terão, assim, muitos carros, mas um deficiente sistema de transporte coletivo; terão muitas fábricas, mas poucos aparelhos antipoluentes. ${ }^{91}$

Podemos, ainda, dar como exemplo a instalação de um farol marítimo, que servirá para todos os navios que passarem pelo trecho onde o farol foi instalado, mas, dificilmente um único dono de navio ou uma única companhia proprietária de embarcações aceitariam arcar com os custos totais de sua instalação, uma vez que outros proprietários de navios também iriam beneficiar-se daquele bem.

\subsubsection{Externalidades}

As externalidades, em essência, acontecem sempre que um indivíduo ou um agente econômico realizam uma ação geradora de um efeito em outro indivíduo ou em outro agente econômico, sem que, por isso, o primeiro indivíduo pague ou já tenha pago. Tal situação acaba por gerar uma ineficiência na alocação de recursos. ${ }^{92}$

Para Nusdeo, como nem sempre todos os custos ou os respectivos benefícios recaem sobre a unidade responsável pela sua condução, como seria o pressuposto, boa parte do cálculo econômico realizado pelos centros decisórios descentralizados passa a ser viciado por não poder incorporar todas as informações relevantes, transmitidas via sistema de preços, de modo que ocorre, assim, uma falha de sinalização. ${ }^{93}$

Tomemos o exemplo bastante elucidativo dado pelo mesmo autor. Considerando o mercado como uma barreira de pedágio das estradas, para poder passar por ela, é necessário que se pague o preço. Porém, se a barreira não for construída ou instalada em um local devidamente calculado e estudado, alguns motoristas poderão valer-se de alguma espécie de atalho ou estrada vicinal, e deixam de arcar com o respectivo preço,

\footnotetext{
${ }^{91}$ Ibidem, p. 160 e 161.

${ }^{92}$ STIGLITZ, Joseph E., Economics of the public sector. $3^{\text {a }}$ ed., New York: Norton \& Company, Inc., 2000, p. 215.

${ }^{93}$ NUSDEO, op. cit., p. 151.
} 
razão por que, claramente, esses motoristas estarão em uma situação mais favorável frente aos demais. Mais que isso, os diretores da estrada estarão recebendo uma informação incorreta acerca do número de usuários. ${ }^{94}$

Por esse tipo de situação, as externalidades também recebem o nome de falha de sinal. Há também quem se utilize do termo em inglês free rider, o que, para nós, apesar da eventual literalidade da tradução, seria mais condizente com o termo carona, aqui também o motivo da expressão "efeito carona".

Vejamos, agora, um exemplo típico de como as externalidades se dão na questão ecológica. Similar ao utilizado por Nusdeo, ${ }^{95}$ imagine uma lavanderia que lave tapetes e, para poder secá-los, a lavanderia precisa estendê-los ao sol. Após algum tempo, uma indústria instala-se em um terreno próximo a essa lavanderia e passa a emitir uma fumaça preta de sua chaminé. A fuligem dessa fumaça fatalmente irá cair sobre os tapetes.

Nessa situação, a lavanderia terá um custo adicional imposto pela indústria, porque, como esta não possui filtros mais potentes ou não exerce a queima total daquele material, e exala resíduos, a lavanderia terá de reenxaguar os tapetes ou construir algum tipo de abrigo para eles.

Muito provavelmente, a lavanderia tentará repassar esse custo aos seus clientes, e, caso eles aceitem o novo preço da lavanderia, na verdade, serão eles que estarão arcando com aquela ineficiência da indústria. Mas, caso os clientes não aceitem, porque preferem ir a uma lavanderia com o preço mais baixo, já que não tem esse tipo de problema, a própria lavanderia terá de arcar com o prejuízo e, provavelmente, ficará prejudicada no âmbito concorrencial, seja em função do seu preço, seja por não poder ampliar seus serviços.

Imagine, agora uma segunda situação semelhante, só que, ao invés de ser uma lavanderia que está nas proximidades da indústria, agora é uma escola ou um parque público. No segundo exemplo, os frequentadores do parque ou os estudantes da escola, certamente terão problemas nas vias respiratórias, e demandarão mais do sistema de saúde local, com consultas médicas ou aquisição de medicamentos.

Esses são alguns exemplos simples de como o problema da poluição se apresenta em relação às externalidades. No entanto, é necessário frisar que as externalidades podem ser positivas ou negativas. Os exemplos citados são típicos de externalidades negativas.

\footnotetext{
${ }^{94}$ Ibidem, p. 152.

95 Ibidem, p. 152-153.
} 
As externalidades positivas, por sua vez, consistem, sinteticamente, na transferência de benefícios ou efeitos positivos a terceiros. Um exemplo típico é o de um apiário instalado próximo a um pomar, de cujas flores as abelhas sugam o néctar que lhes melhorará a produção de mel. ${ }^{96}$ Nesse clássico exemplo agrícola, o dono do apiário terá o benefício externo, e não o dono do pomar.

Um segundo exemplo é o de um indivíduo, que resolve cuidar do jardim e melhorar a fachada da sua casa, numa área não muito bem conservada e com poucas casas com fachadas bonitas. Ao embelezar a sua casa, aquele proprietário estará gerando um benefício também para os seus vizinhos, que terão uma visão mais bonita, e isso, inclusive, poderá valorizar a própria vizinhança e não apenas a sua casa isoladamente.

Percebe-se, dessa forma, que as externalidades podem acarretar duas grandes consequências: a superprodução de bens que gerem externalidades negativas ou a subprodução de bens que gerem externalidades positivas.

Em consequência, é natural que os agentes econômicos, que acabem por fornecer algum tipo de benefício externo às comunidades onde estão instalados, recorram aos respectivos governos a fim de internalizá-los. Essa internalização de benefícios pode dar-se por meio de isenções tributárias, subsídios e outros, e constitui o típico caso das chamadas guerras fiscais, tanto estaduais ou municipais. A depender do tipo de empresa, de quantos benefícios ela poderá gerar naquela comunidade, os Estados ou Municípios passam a oferecer uma grande quantidade de vantagens, entenda-se benefícios fiscais, para que a empresa se instale na sua localidade.

Em relação às externalidades negativas, a ideia é o inverso: os agentes econômicos tendem a se manterem inertes. Somente se o Poder Público se manifestar, com a imposição de algum tipo de sanção ou tributo, é que o agente econômico irá internalizar e absorver aquele custo que, normalmente, ele transferiria para terceiros. No entanto, é importante frisar que não se trata de um problema relativo à ilicitude; ao contrário, o efeito externo aparece quando o ordenamento jurídico se mostra impossibilitado de identificar e atribuir tais custos adequadamente aos seus responsáveis. ${ }^{97}$

Essa forma de internalização das externalidades é consubstanciada nas célebres lições de A.C. Pigou, que preconizam que se deveria tributar as externalidades negativas e subsidiar as positivas. ${ }^{98}$ Essa prática chegou a ser conhecida como imposto pigouviano. É

\footnotetext{
96 Ibidem, p. 155.

${ }^{97}$ Ibidem, p. 153.

${ }^{98}$ PIGOU, Arthur C. The economics of welfare. $4^{\text {th }}$ ed., London: McMillan, 1932, et al.
} 
essa a base da tributação ambiental, tanto em sentido lato, a tributação ambientalmente orientada, quanto em sentido estrito, a tributação ecológica.

Assim, a ideia básica da tributação ambiental consiste em tributar os agentes poluidores, a fim de que se internalizem os custos gerados por eles, e incentivar os que tenham um comportamento ambientalmente correto. No entanto, atualmente, no Brasil, a tendência mais aceita é a de incentivar os agentes que tenham comportamentos desejáveis e rejeitar a tributação dos comportamentos indesejados.

$\mathrm{O}$ argumento da maioria dos autores que rejeitam a tributação dos comportamentos indesejados é consubstanciado no entendimento de que, como o Brasil já tem uma excessiva carga fiscal, que onera pessoas e empresas, não se deve levar em consideração, de forma tão significativa, o preceito constitucional autorizador do aumento da carga fiscal sobre produtos e serviços ecologicamente indesejados. Na verdade, considerados os tributos atualmente existentes e os respectivos efeitos sobre a economia em geral, a aplicação da indução ecológica haverá de se materializar, notadamente, na desoneração fiscal das atividades econômicas que geram, de forma insuspeita, efeitos positivos no meio ambiente. ${ }^{99}$

\subsubsection{Duplo dividendo}

Superada a ideia da neutralidade tributária, isto é, que a tributação deveria, apenas, gerar recursos para os cofres do Estado, sem influenciar nas decisões econômicas dos agentes de mercado ou dos indivíduos, surge a ideia de que a tributação pode induzir comportamentos, que o Estado entende como desejados. Nesse contexto, toda tributação gera, em maior ou menor grau, um efeito fiscal e um efeito indutor.

Admitido, então, que o mercado é falho e o Estado deve preocupar-se em tentar solucionar tais falhas, o tributo passa a ser, também, um instrumento para a correção dessas imperfeições. Em tal contexto, a indução tributária passa a ser considerada não um fator que gera ineficiência, mas o contrário, esse tipo de intervenção econômica almeja o próprio ganho de eficiência econômica ou a realocação de recursos para gerar desenvolvimento econômico. $^{100}$

\footnotetext{
${ }^{99}$ PETTER, Lafayete Josué. ob. cit., p. 281-282.

${ }^{100}$ STIGLITZ, Joseph E., op., cit., p. 463.
} 
Como se vê, a tributação indutora, ou corretiva, seria capaz de produzir algum tipo de reflexo fiscal, o que seria considerado o "primeiro dividendo"; o "segundo dividendo" seria a correção ou minimização da respectiva falha de mercado.

A ideia do duplo dividendo é muito disseminada quando se tenta corrigir as externalidades negativas, em especial, as que geram poluição, porque, segundo a teoria do duplo dividendo, quando se introduz um tributo cujo objetivo seja corrigir determinada externalidade negativa poluidora, o Estado consegue não apenas arrecadar recursos mas também diminuir determinadas condutas poluidoras indesejadas.

Tomemos como exemplo a imposição de um novo tributo sobre a produção ou comércio de cigarros e sobre a queima de combustíveis fósseis, tais como carvão, gasolina e óleo diesel. Nesses casos, haveria um incremento da arrecadação, que poderia ser revertido, no caso do tributo dos cigarros, para o tratamento de saúde de doenças respiratórias causadas pelo fumo, e a diminuição do número de fumantes. No caso do tributo dos combustíveis, a arrecadação poderia ser revertida no tratamento da poluição automotiva e, ainda, seria possível a diminuição dos congestionamentos. ${ }^{101}$

No entanto, é conveniente ressaltar que tais imposições são perfeitamente válidas e úteis, desde que os Governos não tentem utilizar tais argumentos para simplesmente aumentar as suas respectivas cargas fiscais, que, inclusive, é uma das principais preocupações dos estudiosos do assunto. ${ }^{102}$

A tributação ambiental, em regra, é nitidamente extrafiscal, ou seja, não visa, de forma precípua, à arrecadação. Tem como objetivo primário a indução comportamental, sem se ater aos recursos oriundos de tal atividade e consiste, precisamente, em fazer com que o poluidor tenha um custo maior que o não poluidor e, assim, internalize os custos ambientais.

No entanto, situação diversa é a dos Estados que implementaram a chamada Reforma Fiscal Ecológica - RFE. Nesse caso, o tributo ecológico deixa de ser um mero instrumento de defesa do meio ambiente, precipuamente de indução comportamental, e passa a ser, prioritariamente, um meio para que o Estado possa arrecadar recursos e custear as suas despesas, isto é, passa a ser um tributo fiscal ordinário.

Nesse contexto, é importante conhecermos a ideia básica em que consistem as chamadas demandas elásticas e demandas inelásticas. As primeiras são observadas em

\footnotetext{
${ }^{101}$ Ibidem, p. 465.

102 YANDLE, Bruce. Public choice at the intersection of environmental Law and economics. In European Journal of Law and Economics. N. 8, Netherlands, 1999, p. 5 - 27.
} 
bens que possuem uma sensibilidade muito elevada em relação ao preço daquele bem, isto é, conforme a variação do preço, a demanda pelo bem irá aumentar ou diminuir, proporcionalmente. Enquanto nas demandas inelásticas, não há uma variação muito elevada conforme a variação do preço do bem, ao contrário, mesmo que o preço do bem aumente ou diminua, a sua demanda continuará relativamente estável e a variação será baixa. Alguns típicos exemplos de bens que possuem uma demanda inelástica são o cigarro, a água, o sal, as bebidas alcoólicas.

Assim, a imposição de novos tributos ou a majoração de tributos sobre produtos que possuam uma demanda inelástica deve sempre ser vista com muita cautela, já que, é necessário verificar se o argumento que está sendo utilizado para aquela nova imposição ou para a majoração não seja simplesmente fictícia e na realidade, o Estado queira aumentar a arrecadação.

Portanto, há que se atentar para a incessante voracidade fiscal dos Estados, a fim de que estes não introduzam tributos com apelo ambiental, porque é mais fácil de ser aceito pela sociedade, mas que simplesmente visem à arrecadação fiscal.

\subsection{PROTEÇÃO AMBIENTAL}

Sob forte influência da Declaração de Estocolmo de 1972, ${ }^{103}$ a Constituição Federal de 1988, pela primeira vez na história constitucional e da proteção ambiental brasileira, trouxe um capítulo próprio acerca da proteção do meio ambiente e vinculou o ambiente à sadia qualidade de vida, Capítulo VI, art. 225, da CF/88.

\footnotetext{
“Art. 225 Todos têm direito ao meio ambiente ecologicamente equilibrado, bem de uso comum do povo e essencial à sadia qualidade de vida, impondo-se ao Poder Público e à coletividade o dever de defendê-lo e preservá- lo para as presentes e futuras gerações. (grifo nosso)"
}

\footnotetext{
${ }^{103}$ A Declaração de Estocolmo de 1972 foi o resultado da I Conferência Mundial sobre o Homem e o Meio Ambiente organizada pela ONU. Nessa mesma conferência, o Clube de Roma, uma organização internacional não governamental, apresentou o relatório chamado de "Limites do Crescimento", elaborado por cientistas do Massachusetts Institute of Technology - MIT, o qual, em essência, previa o colapso da civilização humana caso não fossem tomadas medidas drásticas em relação à forma e ao ritmo do crescimento econômico da época.
} 
Nesse contexto, Manoel Gonçalves afirma que a Constituição sedimentou o direito, de $3 .^{\mathrm{a}}$ geração $^{104}$, de todos terem um ambiente ecologicamente equilibrado, essencial à sadia qualidade de vida e tal direito foi posto sob a proteção da coletividade e do Poder Público, de forma conjunta. ${ }^{105}$

Ingo Sarlet entende que a Constituição, com base no art. 5., §2 e art. 225, sedimentou e positivou, ao longo de todo o seu texto, os fundamentos normativos de um verdadeiro constitucionalismo ecológico e garantiu o direito ao ambiente o status de direito fundamental, em sentido formal e material, orientado pelo princípio da solidariedade. ${ }^{106}$

José Afonso da Silva é mais enfático e assevera que é importante que se tenha consciência de que o direito à vida, como base de todos os demais direitos fundamentais do homem, é o que deve orientar todas as formas de atuação no campo da tutela do meio ambiente. $^{107}$

Desse modo, não há dissonância na doutrina, tampouco na própria jurisprudência acerca da natureza de direito fundamental do ambiente ecologicamente equilibrado, como bem essencial à sadia qualidade de vida. $\mathrm{O}$ grande problema consiste em saber como implementar esse direito, em como fazer valer esse direito social, já que ele há de ser compreendido com o desenvolvimento econômico.

Nesse contexto e para os fins deste estudo, outro dispositivo de extrema importância é o art. 170, da CF/88. Nele estão esculpidos os princípios que regem a Ordem Econômica. E um desses princípios é o da defesa do meio ambiente, inciso VI, que teve sua redação modificada e $\operatorname{ampliada}^{108}$ pela Emenda Constitucional - EC 42/03, o qual passou a ter a seguinte redação:

“Art. 170. A ordem econômica, fundada na valorização do trabalho humano e na livre iniciativa, tem por fim assegurar a todos existência digna, conforme os ditames da justiça social, observados os seguintes princípios:

$(\ldots)^{\prime \prime}$

\footnotetext{
${ }^{104}$ Segundo Paulo Bonavides, com base em Karel Vasak, os direitos de terceira geração não compreendem unicamente a proteção específica de direitos individuais ou coletivos. São direitos dotados de altíssimo teor de humanismo e universalidade. Foram cristalizados no final do século XX como direitos que não se destinam especificamente à proteção dos interesses de um único indivíduo, de um grupo ou de um Estado. Têm como primeiro destinatário o próprio gênero humano, num momento expressivo de sua afirmação como valor supremo em termos de existencialidade concreta. BONAVIDES, Paulo. Op. cit., p. 569.

${ }^{105}$ FERREIRA FILHO, Manoel Gonçalves. Curso de direito constitucional. 38 ed., São Paulo: Saraiva, 2012 , p. 402.

106 SARLET, Ingo Wolfgang. Direito constitucional ambiental: Constituição, direitos fundamentais $e$ proteção do ambiente. $2^{\mathrm{a}}$ ed., São Paulo: Revista dos Tribunais, 2012, p. 39-40.

107 SILVA, José Afonso da. Ob. cit., p. 70.

${ }^{108}$ Na redação anterior, o dispositivo simplesmente previa: "VI - defesa do meio ambiente"
} 
"VI - defesa do meio ambiente, inclusive mediante tratamento diferenciado conforme o impacto ambiental dos produtos e serviços e de seus processos de elaboração e prestação;"

Percebe-se, de plano, as nítidas ideias de desenvolvimento sustentável abordadas anteriormente, uma vez que, já no caput do dispositivo, surgem as expressões assegurar a todos existência digna, conforme os ditames da justiça social.

André Ramos Tavares, comentando o referido dispositivo, entende que a exploração dos recursos naturais necessários ao desenvolvimento econômico do país deve ser pautada pelas diretrizes do chamado desenvolvimento sustentável, oposto, portanto, da devastação ambiental inconsequente e excessiva. ${ }^{109}$

No mesmo sentido, Lafayete Petter afirma que a defesa do meio ambiente impõe uma modificação nos parâmetros do desenvolvimento da atividade econômica, como a que vem ocorrendo na ideologia dominante. ${ }^{110}$

Avançando na ideia de defesa do meio ambiente e no que dispõe o referido dispositivo, Hugo de Brito Machado afirma que o tributo pode e deve ser utilizado em sua função extrafiscal para a defesa do meio ambiente. ${ }^{111}$

Lídia Maria Ribas, da mesma forma, tendo como fundamento os art. 170, VI, e 225, aliados ao princípio da seletividade em função da essencialidade, afirma que o legislador pode, em caráter extrafiscal, desestimular as atividades inconvenientes ao bemestar social. A majoração de alíquotas incidentes sobre produtos ecologicamente incorretos ainda tem a vantagem de permitir a transferência dos custos sociais causados pelo dano para as indústrias poluentes. ${ }^{112}$

Como se pode perceber, a doutrina é pacífica em aceitar a tributação indutora como um mecanismo de defesa do meio ambiente. A ideia de utilizar os instrumentos econômicos como medidas de proteção ambiental vem ganhando força progressivamente.

Ainda, a Lei 6.938/1981, que estabelece a Política Nacional do Meio Ambiente, mesmo antes da nossa atual Constituição, já trazia a ideia de assegurar as condições para o desenvolvimento sócioeconômico e proteção da dignidade da vida humana.

${ }^{109}$ TAVARES, André Ramos. Direito constitucional econômico. $3^{\text {a }}$ ed., Rio de Janeiro: Forense; São Paulo: MÉTODO, 2011, p. 187.

${ }^{110}$ PETTER, Laafayete Josué. Ob. cit., (nota 28), p. 275.

${ }^{111}$ MACHADO, Hudo de Brito. Ordem econômica e tributação. In FERRAZ, Roberto Catalano Botelho (coord.) - Princípios e limites da tributação 2 - Os princípios da Ordem Econômica e a tributação. São Paulo: Quartier Latin, 2009, p. 384.

${ }_{112}$ RIBAS, Lídia Maria Lopes Rodrigues. Defesa ambiental: utilização de instrumentos tributários. In TÔRRES, Heleno Taveira. Direito tributário ambiental. São Paulo: Malheiros Editores, 2005, p. 686. 
“Art $2^{\circ}$ - A Política Nacional do Meio Ambiente tem por objetivo a preservação, melhoria e recuperação da qualidade ambiental propícia à vida, visando assegurar, no País, condições ao desenvolvimento sócioeconômico, aos interesses da segurança nacional e à proteção da dignidade da vida humana, atendidos os seguintes princípios: (...) (grifo nosso).”

A doutrina é pacífica no uso da tributação ambientalmente orientada, isto é, no uso dos tributos já existentes, mas com algum tipo de componente ambiental que possa ser usado como elemento de discrímem para a essencialidade ambiental. No entanto, a grande questão que se coloca no nosso atual sistema é se o art. 170, VI, CF/88, é suficiente para permitir a tributação direta de algum fato poluidor, isto é, se seria possível tributar a própria emissão de fumaça poluidora, ou o despejo de substâncias poluidoras nas águas ou o descarte de material poluidor no solo, com base, apenas, no referido dispositivo. 


\section{ORDEM TRIBUTÁRIA, ORDEM ECONÔMICA E DEFESA DO MEIO AMBIENTE}

Para que possamos entender a tributação de fatos causadores de efeitos ambientalmente indesejados, ou seja, o tributo ecológico, é necessário, primeiramente, que tenhamos uma visão sistêmica do ordenamento jurídico. Com o intuito de verificarmos como se dá a interação entre os subsistemas da ordem tributária, da ordem econômica e da defesa do meio ambiente, primeiramente iremos fazer algumas considerações acerca da própria ideia de sistema jurídico.

Paulo de Barros Carvalho faz uma advertência importante em relação à ideia de sistema e ordenamento. Segundo o autor, vários estudiosos fazem uma diferenciação entre os dois termos. Os autores que fazem tal distinção entendem que o direito posto não alcançaria o status de sistema, termo este que seria reservado apenas para as contribuições dos cientistas, dos juristas que compõem as partes e, então, dão um sentido de um todo organizado, isto é, ordenamento jurídico e direito positivo ficariam de um lado, enquanto sistema e Ciência do Direito ficariam do outro. No entanto, os dois últimos termos implicariam os primeiros. ${ }^{113}$

Carvalho faz fortes críticas a respeito da distinção entre sistema e ordenamento, para, ao final, afirmar que, na sua obra, empregaria os referidos termos como sinônimos. ${ }^{114}$ Valendo-nos da advertência feita acima e concordando com o autor, também empregaremos os termos como sinônimos.

Canaris, em extenso estudo sobre os diferentes conceitos de sistemas, afirma que as características comuns de todos os conceitos de sistema são a ordem e a unidade, que têm suas correspondências jurídicas nas ideias de adequação valorativa e unidade interna do ordenamento jurídico. ${ }^{115}$ Para o autor, as respectivas características podem ser entendidas como premissas decorrentes da própria ideia de Direito.

Ao decorrer da ideia de Direito, a ordem é o resultado direto do reconhecimento do próprio postulado de justiça, de tratar o igual de modo igual e o

${ }^{113}$ CARVALHO, Paulo de Barros. Direito tributário: linguagem e método. $4^{\mathrm{a}}$ ed., São Paulo: Noeses, 2011, p. 217.

${ }_{114}^{114}$ Ibidem, p. 218.

115 CANARIS, Claus - Wilhelm. Pensamento sistemático e conceito de sistema na ciência do direito. Traduzido do original alemão intitulado: Systemdeken und Systembegriff in der Jurisprudenz, 2. Auflage, 1983, por António Manuel da Rocha e Menezes Cordeiro, Lisboa: Fundação Calouste Gulbenkian, 1989, p. 12. 
desigual de maneira desigual, na medida da sua diferença. Tanto o juiz, como o legislador, devem proceder com adequação aos valores encontrados no ordenamento. Eis a razão da regra da adequação valorativa, extraída do princípio da igualdade. Enquanto a unidade da ordem jurídica possui dois componentes, em sentido negativo, também emana do princípio da igualdade, no sentido de garantir a ausência de contradições da ordem jurídica. Em sentido positivo, representa a realização da "tendência generalizadora" da justiça, pois supera os numerosos aspectos, possivelmente relevantes do caso concreto, em prol de uns poucos princípios, abstratos e gerais. Dessa forma, garante-se que a ordem do Direito não seja esvaziada em uma variedade de valores singulares desconexos e efetive-se a característica da unidade. ${ }^{116}$

Hector Villegas, igualmente, apresenta o conceito de unidade do direito como pressuposto fundamental para se entender os diferentes ramos da ciência jurídica. Para o autor argentino, não existe a possibilidade de independência absoluta ou de fronteiras fechadas entre os diferentes ramos jurídicos. Os diferentes setores jurídicos em que se divide o direito não deixam de formar, em sua essência, o caráter de partes de uma única unidade cientifica. Por isso, a autonomia de um ramo jurídico nunca pode significar total liberdade para se regular integralmente de forma isolada. A autonomia, em qualquer sentido que se tome, não pode ser concebida de maneira absoluta, pois cada ramo do direito é parte de um todo do qual é porção integrante. ${ }^{117}$

Ricardo Lobo Torres aceita a ideia de unidade, mas afirma que não há uma totalidade na Constituição e o que existe, na verdade, é um conjunto de subsistemas com unidade interna e coerência. No entanto, todos os subsistemas se apresentam com unidade e coerência, em constante tensão e equilíbrio, sem desarmonia e contradições dentro da Constituição. ${ }^{118}$

Da ideia de sistema, podemos extrair uma correlação bastante intuitiva, a da interpretação sistemática. Gilmar Mendes, ao abordar o tema da interpretação constitucional, mais especificamente regra da unidade da Constituição, afirma que as normas constitucionais não devem ser vistas como normas isoladas, mas, sim, como disposições integradas num sistema unitário de regras e princípios, instituído pela própria Constituição. Em tal contexto, como decorrência, a Constituição só pode ser compreendida

\footnotetext{
${ }^{116}$ Ibidem, p. $18-21$.

${ }^{117}$ VILLEGAS, Héctor Belisario. Curso de finanzas, derecho financeiro y tributário. $9^{\mathrm{a}}$ ed., Buenos Aires, Editorial Astrea de Alfredo y Ricardo Depalma, 2009, p. 85.

118 TORRES, Ricardo Lobo. Tratado de direito constitucional financeiro e tributário. vol. I-constituição financeira, sistema tributário e estado fiscal. Rio de Janeiro: Renovar, 2009, p. 265-266.
} 
e interpretada corretamente se for entendida como uma unidade. Assim, olhando por outro lado deste mesmo prisma, não há como separar uma norma do conjunto em que ela se integra, porque o sentido da parte e o sentido do todo são interdependentes. ${ }^{119}$

Da mesma forma, porém mais sintética, Eros Grau entende que a interpretação do direito só é interpretação do direito, no seu todo, não de textos isolados, desprendidos do direito, não sendo possível a interpretação do direito em tiras, ou aos pedaços. ${ }^{120}$

Juarez Freitas afirma que qualquer exegese comete, direta ou indiretamente, uma aplicação de princípios, de regras e de valores componentes da totalidade do Direito. Para o autor, não se deve considerar a interpretação tópico-sistemática como simples elemento da interpretação jurídica. A interpretação tópico-sistemática, entendida em profundidade, é o processo hermenêutico por excelência, de tal maneira que, ou se compreendem os enunciados prescritivos no entrelaçamento dos demais enunciados, ou não se consegue compreendê-los sem perdas substanciais. Ao concluir seu raciocínio, Freitas assevera que interpretar uma norma é interpretar o sistema inteiro, é aplicar o Direito na sua totalidade, para além de sua dimensão textual, pois a interpretação jurídica ou é sistemática ou não é interpretação. ${ }^{121}$

Assim, partindo da ideia de que um sistema jurídico é dotado de unidade e ordem, vejamos as principais características do subsistema tributário, para, em seguida, analisarmos os princípios constitucionais mais relevantes para a eventual imposição de um tributo ecológico.

\subsection{NOÇÕES DE SISTEMA TRIBUTÁRIO}

Como vimos no tópico anterior, um dado sistema jurídico é composto por um conjunto de subsistemas, dotados de ordem e unidade. A partir de agora, iremos concentrar-nos em apenas um desses subsistemas, o subsistema constitucional tributário. Com este tópico, pretendemos demonstrar quais os principais mandamentos constitucionais acerca da imposição tributária em nosso ordenamento jurídico.

\footnotetext{
${ }^{119}$ MENDES, Gilmar Ferreira. Curso de direito constitucional. São Paulo: Saraiva, 2007, p. 107.

${ }^{120}$ GRAU, Eros Roberto. Ensaio e discurso sobre a interpretação/aplicação do direito. $5^{a}$ ed., São Paulo: Malheiros Editores, 2009, p. 44.

${ }^{121}$ Ibidem, p. 76, grifos originais.
} 
Günter Schmölders afirma que a simples justaposição dos impostos vigentes em um dado ordenamento jurídico não compõe, por si só, um conjunto ordenado e lógico, isto é, um "sistema tributário". Citando Adolfo Wagner, o autor entende que essa expressão é um eufemismo equivocado para designar o caos dos impostos. ${ }^{122}$

Para Schmölders, o conceito de sistema tributário implica certa coordenação dos diferentes impostos entre si, em conjunto com o sistema econômico dominante, com os fins fiscais e extrafiscais da imposição tributária. ${ }^{123}$

Confirmando a ideia de que o Direito Tributário é apenas um subsistema do sistema maior que é a Constituição e deve ser entendido como uma unidade ordenada, Klaus Tipke ${ }^{124}$ assevera que o Direito Tributário é parte do Ordenamento Jurídico global. Afirma, ainda, que a liberdade de contraposição dos valores fundamentais do Direito e da Justiça são elementos essenciais de um Ordenamento, isto é, se o legislador fixou valores fundamentais em uma parte do Ordenamento, então, obrigatoriamente, ele também irá observá-los em outros setores do Ordenamento, em razão do postulado da Unidade do Ordenamento Jurídico.

Ricardo Lobo Torres, ao entender que o sistema jurídico é formado por vários outros subsistemas oriundos da própria Constituição, afirma que esses subsistemas formam verdadeiras "subconstituições". Nesse sentido, o autor carioca afirma existir a subconstituição Tributária, a Econômica, a Penal, a Política e a Social e que elas entram em constante tensão. ${ }^{125}$

Especificamente sobre as subconstituições econômica e tributária, Torres afirma que elas se apresentam com maior grau de intimidade e profundidade, ja que estão em constante equilíbrio, influenciando-se mutuamente e relacionando-se em toda a extensão dos fenômenos econômicos e financeiros. ${ }^{126}$

Dissertando acerca das fontes do direito tributário, Alejandro Altamiro entende que tudo está em consonância com a Constituição. Afirma, ainda, que, para o Direito Tributário, a Constituição assume o papel principal de iluminar as diretivas fundamentais

\footnotetext{
${ }^{122}$ SCHMÖLDERS, Günter. Teoria general del impuesto. Traducción de Luis A. Martín Merino, Madrid: Editorial de Derecho Financiero, 1962, p. 221.

123 Ibidem.

${ }^{124}$ TIPKE, Klaus. Direito tributário. Tradução da 18 ed. Alemã, totalmente refeita, de Luiz Doria Furquim. Porto Alegre: Sergio Antonio Fabris Ed., 2008, p. 68.

${ }^{125}$ TORRES, Ricardo Lobo. op, cit, p. 273.

${ }^{126}$ Ibidem, p. 278.
} 
dentro das quais se desenvolve o poder de tributar. Como consequência, os direitos e obrigações tanto do Estado como do contribuinte convergem para a Constituição. ${ }^{127}$

Humberto Ávila afirma que o Sistema Tributário Nacional regula pormenorizadamente a matéria tributária, mas que mantém relação com toda a Constituição, em especial, com os princípios formais e materiais fundamentais, previstos de forma expressa ou implícita, com os direitos fundamentais, especialmente com as garantias de propriedade e de liberdade. Afirma, ainda, que o princípio republicano, federativo, da segurança jurídica e da igualdade, são os princípios sistematicamente fundamentais, isto é, são eles que mantêm vinculação com o poder de tributar e atribuem significado normativo a outros princípios. ${ }^{128}$

De maneira muito didática e esclarecedora, Roque Carrazza afirma que a Constituição é a base de todo nosso direito público, especialmente do nosso direito tributário. Nesse sentido, não se pode esquecer que todos os artigos da Constituição só encontram sua real dimensão se conjugados com os princípios magnos do nosso sistema constitucional. $^{129}$

Para Ruy Barbosa Nogueira, o Direito Constitucional Tributário é o conjunto de princípios e normas que regulam o poder tributário do Estado, que disciplina não só o poder tributário e o seu exercício, mas, sobretudo, os limites desse poder. ${ }^{130}$

Assim, no texto constitucional, podemos visualizar a fundamentação jurídica para a própria criação dos tributos, isto é, na Constituição, encontramos a competência tributária, que diz quem são as pessoas jurídicas de direito público que poderão instituir tributo e qual tributo este ente poderá instituir.

Dessa forma, partindo da ideia de um sistema constitucional, encontramos dentro desse conjunto maior um subsistema constitucional tributário, construção que não deixa dúvida de que na Constituição encontramos as bases do direito tributário e os limites do poder tributário. Em tal sentido, se é verdadeiro que o direito tributário deve observar princípios próprios, é verdadeiro, também, que o direito tributário não pode olvidar o respeito a outros princípios, também, inseridos no texto constitucional, mas que não integram, de forma direta e imediata, o subsistema tributário.

\footnotetext{
127 ALTAMIRO, Alejandro C. Derecho tributario teoría general. Marcial Pons. Madrid, 2012, p. 176.

128 ÁVILA, Humberto.

${ }^{129}$ CARRAZZA, Roque Antonio. Curso de direito constitucional tributário. $25^{\mathrm{a}}$ ed., São Paulo: Malheiros Editores, 2009, p. 60-61.

${ }^{130}$ NOGUEIRA, Ruy Barbosa. Curso de direito tributário. 15 ed., São Paulo: Saraiva, 1999, p. 117 e 125.
} 


\subsection{PRINCÍPIOS CONSTITUCIONAIS RELEVANTES}

Feitas algumas breves considerações sobre a ideia de sistema, agora iremos debruçar-nos, especificamente, sobre alguns princípios jurídicos que compõem esse sistema e cuja escolha não foi aleatória e, sim consubstanciada na ideia de que, no conteúdo normativo de cada um desses princípios, a tributação ambiental enfrenta suas maiores dificuldades, ou melhor, é apenas com a conciliação desses princípios que se poderá cogitar da instituição de um tributo ecológico no nosso ordenamento jurídico.

Antes de adentrarmos, especificamente, no conteúdo normativo de cada princípio, é conveniente fazermos algumas breves considerações acerca do que significado de um princípio jurídico. No entanto, para que seja alcançado tal fim, é imperioso que se tracem algumas breves diferenças destes em relação às regras, embora seja salutar o entendimento de que na doutrina especializada ainda não há unicidade de pensamento a respeito do tema.

Sendo assim, com o intuito de não adentrar nas complexidades do tema, limitar-nos-emos a expor o nosso entendimento. Nesse sentido, partimos da premissa de que princípio e regra são espécies do gênero norma jurídica, uma vez que ambas as espécies estão no plano deontológico e dizem o que deve ser. ${ }^{131}$

No entanto, a observação feita por Humberto Ávila acerca da diferenciação entre texto e norma, parece-nos bastante oportuna. Conforme o autor, normas não são textos nem o conjunto deles, mas, sim, os sentidos construídos com base na interpretação sistemática de textos normativos, ou seja, as normas são o resultado da interpretação dos dispositivos jurídicos. ${ }^{132}$

Com base na teoria dos princípios, a principal diferença entre regras e princípios é a estrutura que essas normas garantem. ${ }^{133}$ Os princípios garantem direitos ou impõem deveres prima facie. As normas ordenam que algo seja realizado na maior medida possível dentro das possibilidades jurídicas e fáticas existentes, isto é, são entendidas como mandamentos de otimização. ${ }^{134}$

${ }^{131}$ ALEXY, Robert. Teoria dos direitos fundamentais. Tradução de Virgílio Afonso da Silva. São Paulo: Malheiros Editores, 2008, p. 87.

${ }_{132}$ ÁVILA, Humberto. Teoria dos princípios, da definição à aplicação dos princípios jurídicos. $7^{\mathrm{a}}$ ed., São Paulo: Malheiros Editores, 2008, p. 30.

${ }^{133}$ SILVA, Virgílio Afonso. Direitos fundamentais: conteúdo essencial, restrições e eficácia. $2^{a}$ ed., São Paulo: Malheiros Editores, 2010, p. 45. Grifo original.

${ }^{134}$ Alexy, Robert. op., cit., p. 90. 
Enquanto as regras garantem direitos ou impõem deveres definitivos, são determinações. São normas sempre satisfeitas ou não satisfeitas, isto é, se uma regra é válida, ela deve ser aplicada de forma integral e estrita, nem mais, nem menos. ${ }^{135}$

Vejamos, então, os princípios constitucionais que nos parecem mais relevantes para a eventual tributação ecológica.

\subsubsection{Legalidade}

O princípio da legalidade decorre da própria ideia de Estado de Direito, art. 5º, II, CF/88. "II- ninguém será obrigado a fazer ou deixar de fazer alguma coisa senão em virtude de lei." Segundo André Ramos Tavares esse princípio funda-se na exigência de legitimidade, segundo a qual as leis hão de guardar correspondência com os anseios populares, consubstanciados no espírito constitucional. ${ }^{136}$

No entanto, no que tange à tributação, o constituinte entendeu por bem introduzir outro dispositivo, art. 150, II, CF/88, este específico para matéria tributária.

“Art. 150. Sem prejuízo de outras garantias asseguradas ao contribuinte, é vedado à União, aos Estados, ao Distrito Federal e aos Municípios:

I - exigir ou aumentar tributo sem lei que o estabeleça;"

É conveniente, então, investigarmos, mesmo que de forma breve, as origens desse princípio. Tradicionalmente se atribui à Magna Carta, de 1215, assinada pelo Reio João Sem Terra, da Inglaterra, as origens desse princípio. Na época, após inúmeros abusos e revoltas, os nobres ingleses obrigaram o então Rei a assinar o documento que limitava os seus poderes. Dentre as inúmeras cláusulas, numa delas estava previsto o princípio do " $n o$ taxation without representation", isto é, não haverá tributação, sem representação. ${ }^{137}$

No entanto, Schoueri afirma que o direito de concordar com a tributação (e de controlar gastos) é uma das mais antigas lembranças do sentimento do direito e do dever de

\footnotetext{
${ }^{135}$ Ibidem, p. 91.

136 TAVARES, André Ramos. Curso de direito constitucional. 9a ed., São Paulo: Saraiva, 2011, p. 664.

${ }^{137}$ Fábio Konder Comparato, na obra A afirmação histórica dos direitos humanos. São Paulo: Ed. Saraiva, 1999, traz uma cópia traduzida da célebre Carta, o dispositivo que nos interessa: "1. Não lançaremos taxas ou tributos sem o consentimento do conselho geral do reino (commue concilium regni), a não ser para resgate da nossa pessoa, para armar cavaleiro nosso filho mais velho e para celebrar, mas uma única vez, o casamento da nossa filha mais velha; e esses tributos não excederão limites razoáveis. De igual maneira se procederá quanto aos impostos da cidade de Londres."
} 
participar, oriundo das corporações de ofícios. Dentre os exemplos fornecidos pelo autor, o mais antigo remonta ao ano de 614, com o Edito de Paris. ${ }^{138}$

É cediço que a tributação, ou melhor, o abuso e o excesso do poder de tributar pelo Estado já geraram inúmeras revoltas. Apenas para citar algumas, a "Boston Tea Party" de 1773, que acabou por desencadear a Revolução dos Estados Unidos, a própria Revolução Francesa, e, ainda aqui no Brasil, o "quinto do ouro e a derrama".

Consubstanciado no dispositivo específico da legalidade tributária, Carrazza afirma que o princípio da legalidade é um limite intransponível à atuação do Fisco. Este princípio garante, decisivamente, a segurança das pessoas, diante da tributação. Destaquese que essa segurança deve ser entendida, também, como segurança patrimonial, ou direito de propriedade, já que a proteção à propriedade privada, arts. 5, XXII, e 170, II, se tornaria inócua caso inexistisse a garantia rígida e solene de que os tributos não seriam fixados ou alterados pelo Poder Executivo, mas apenas pela lei. ${ }^{139}$

Sacha Calmon, ao fazer um paralelo entre a legalidade tributária e a legalidade penal, afirma que nullum tributum, nnulla poena sine lege. Para o autor, Estão de Direito e legalidade na tributação são termos equivalentes. Dessa forma, onde houver Estado de Direito, obrigatoriamente, haverá obediência ao princípio da reserva de lei em matéria de lei tributária. E, onde prevalecer o arbítrio tributário, certamente inexistirá Estado de Direito, o que, por consequência, acarretará a ausência da liberdade e da segurança. ${ }^{140}$

José Juan Lapatza também noticia que o princípio da legalidade surge na história ligado, essencialmente, a duas matérias, que indicam a condição de súdito ou cidadão livre ao membro de uma sociedade, a definição de delitos e penas e o estabelecimento de tributos. Diante de uma sociedade livre, apenas a própria comunidade pode impor a si mesma as normas que definem delitos e penas, e a quantidade com que cada um de seus membros deve sustentar os gastos da coletividade, os tributos. ${ }^{141}$

Nesse contexto, as lições depreendidas do extenso estudo efetuado por Gerd Rothmann sobre o assunto parecem atemporais, porque, já em 1973, Rothmann alertava

\footnotetext{
${ }^{138}$ SCHOUERI, Luís Eduardo. Direito tributário. op. cit., p. 269. Segundo o autor, o Edito de Paris foi um "tratado entre rivais no reino dos Francos, que se estendia pela maior parte setentrional da Europa, cobrindo a França, Países Baixos e Alemanha. Houve uma grande assembleia que resultou no referido Edito, segundo o qual em qualquer lugar onde um novo tributo fosse dolosamente introduzido e incitado o povo à resistência, $\mathrm{o}$ assunto seria investigado e o tributo seria bondosamente abolido, ali se identificava a proibição contra um tributo inaudito ("exactio inaudita").

${ }^{139}$ CARRAZZA, Roque Antonio. op., cit., p. 256-257.

${ }^{140}$ COÊLHO, Sacha Calmon Navarro. Curso de direito tributário brasileiro. Rio de Janeiro: Forense, 2009, p. 178.

${ }^{141}$ FERREIRO LAPATZA, José Juan. Direito tributário: teoria geral do tributo. Barueri, SP: Manole; Espanha, ES: Marcial Pons, 2007, p. 8.
} 
para a necessidade de leis no sentido material, e não apenas formal, isto é, leis que sejam emanadas do próprio Poder Legislativo, uma vez que a instituição de tributos deve passar, necessariamente, pelo órgão de representação popular. Em um Estão de Direito, só há que se falar em legalidade da tributação quando as leis tributárias são elaboradas por um órgão distinto daquele que tem a função de aplicá-las. ${ }^{142}$

Portanto, é certo que a legalidade da tributação surge como um instrumento de defesa do cidadão contra a voracidade e o abuso do poder de tributar do Estado. No entanto, essa não é a sua única feição. Ricardo Lobo Torres afirma que o princípio da legalidade tributária decorre de um valor maior, que é segurança jurídica, e a tipicidade, a irretroatividade e a anterioridade seriam subprincípios decorrentes da legalidade. ${ }^{143}$

Neste momento, então, importante lembrar a observação feita por Ávila, no sentido de que de um mesmo dispositivo pode ser extraída mais de uma norma, e, no caso de vários dispositivos a partir da junção deles, pode ser extraída uma única norma. Como é o caso do enunciado da legalidade, na primeira hipótese, o autor extrai do texto que exige lei para a instituição ou aumento de tributos, o princípio da legalidade, o princípio da tipicidade, a proibição de delegação normativa e a proibição de regulamentos independentes. Já na segunda hipótese, dos dispositivos que preveem a legalidade, a irretroatividade e anterioridade, chega-se ao princípio da segurança jurídica. ${ }^{144}$

Sem ingressar na discussão se a legalidade decorre da segurança jurídica, ou se esta decorre daquela, visto que não é esse o nosso objetivo, certo é que o princípio da legalidade tributária está intrinsecamente ligado à segurança jurídica, à tipicidade ${ }^{145}$ da tributação e à anterioridade. Todos esses princípios, sem dúvida, estão vinculados a valores maiores, quais sejam a certeza e a segurança do cidadão contra o Estado.

Sendo assim, por estar em maior harmonia com os fins deste trabalho e por, em última análise, a anterioridade e a irretroatividade serem corolários da segurança jurídica, neste momento, faremos apenas algumas considerações acerca do princípio da segurança jurídica em matéria tributária.

\footnotetext{
${ }^{142}$ ROTHMANN, Gerd Willi. O princípio da legalidade tributária. in Direito tributário: estudo de casos e problemas, $5^{a}$ coletânea. Direção e colaboração, NOGUEIRA, Ruy Barbosa. São Paulo: Bushatsky, 1973, p. $137-180$.

${ }^{143}$ TORRES, Ricardo Lobo. Tratado de direito constitucional financeiro e tributário. vol. II - Valores e princípios constitucionais tributários. Rio de Janeiro: Renovar, 2005, p. 399-400.

144 ÁVILA, Humberto. Op., cit., p. 30-31.

145 Em relação à tipicidade da tributação, deixaremos para abordar o tema no Capítulo 4, quando formos tratar dos elementos que compõem um tributo. Neste momento, basta afirmar que todos os elementos que compõem o tributo, obrigatoriamente, devem ser previstos em lei.
} 
Nesse sentido, a segurança jurídica com a anterioridade, a irretroatividade, a tipicidade e a própria legalidade garantem ao cidadão, além da própria segurança, a não surpresa contra atos do Estado, isto é, por meio dessas normas, o cidadão tem a garantia de que não vai ser tributado de forma inesperada, bem como a certeza de qual tributo e do quantum que terá de pagar.

Da mesma forma, compreende Sacha Calmon. O autor entende que a anterioridade e a irretroatividade asseguram a ideia de que a lei tributária deve ser conhecida com antecedência, de modo que os contribuintes tenham a certeza e a segurança a que tipo de gravame estarão sujeitos no futuro imediato e possam, dessa forma, organizar e planejar seus negócios e atividades. E, em relação à irretroatividade, entende que deflui da necessidade de assegurar às pessoas segurança e certeza quanto a seus atos pretéritos em face da lei. ${ }^{146}$

Humberto Ávila, em extensa obra dedicada integralmente ao estudo da segurança jurídica, conclui que ela, apesar de ser um ideal normativo de primeira grandeza, em qualquer ordenamento jurídico, possui maior importância no âmbito da tributação. A Constituição não apenas exige o princípio, mas corporifica-o, por meio da preocupação, do inicio ao fim, com os ideias da confiabilidade, da calculabilidade e da cognoscibilidade. ${ }^{147}$

Para Ávila, cognoscibilidade seria um estado de coisas em que os cidadãos possuiriam, em alta medida, a capacidade de compreensão, material e intelectual, de estruturas argumentativas reconstrutivas de normas gerais e individuais, materiais e procedimentais, que assegurassem certa "segurança de orientação" a ser efetivada por meio da acessibilidade, abrangência, clareza, determinabilidade e executoriedade das normas. ${ }^{148}$

A confiabilidade seria o estado ideal em que o cidadão sabe quais mudanças poderão ser feitas e quais não poderão ser efetivadas. Esse ideal só seria possível se o cidadão pudesse ter assegurados, hoje, os efeitos que lhe foram garantidos pelo Direito ontem. No ideal da calculabilidade, teríamos o estado ideal no qual o cidadão poderia saber como e quando as mudanças poderiam ser realizadas, e, assim, impedir a surpresa. Aqui, inversamente ao anterior, esse ideal só seria possível se o cidadão pudesse controlar, hoje, os efeitos que lhe serão imputados pelo Direito amanhã.

\footnotetext{
${ }^{146}$ COÊLHO, Sacha Calmon Navarro. op., cit., p. 178.

147 ÁVILA, Humberto. Segurança jurídica, entre permanência, mudança e realização no Direito Tributário. São Paulo: Malheiros Editores, 2011, p. 665.

${ }^{148}$ Ibidem.
} 


\subsubsection{Igualdade e capacidade contributiva}

Sem a pretensão de voltarmos muito na História, parece-nos suficiente afirmar, visto que se trata de fato incontroverso, que as grandes revoluções sociais sempre tiveram, em maior ou menor grau, dois elementos comuns: alguma circunstância econômica e algum tipo de privilégio ou situação que afrontasse a igualdade. Sendo assim, no atual momento histórico em que nos encontramos, e, principalmente em razão do atual estágio de evolução da Teoria do Estado que possuímos, é seguro afirmar que o Estado Democrático de Direito é impensável sem a observância do princípio da igualdade.

O princípio da igualdade pode ser entendido como uma verdadeira exigência da própria ideia de Justiça. ${ }^{149}$ Assim, é um dos princípios mais elementares de todo e qualquer ordenamento jurídico moderno. Nesse sentido, Victor Uckmar é contundente ao afirmar que a igualdade de direitos e deveres dos cidadãos é um dos imperativos categóricos estatuído em todas as Constituições. ${ }^{150}$

Em nosso ordenamento jurídico, a igualdade é prevista em inúmeros dispositivos constitucionais. De forma genérica, é prevista no art. $3^{\circ}$, por meio do ideal de justiça, e, expressamente, no art. $5^{\circ}$, caput.

\footnotetext{
“Art. 3. ${ }^{\circ}$ Constituem objetivos fundamentais da República Federativa do Brasil: I - construir uma sociedade livre, justa e solidária; (grifo nosso)"

"Art. 5. Todos são iguais perante a lei, sem distinção de qualquer natureza, garantindo-se aos brasileiros e aos estrangeiros residentes no País a inviolabilidade do direito à vida, à liberdade, à igualdade, à segurança e à propriedade, nos termos seguintes:"
}

De maneira mais ampla, ao elencar como objetivo fundamental da República a construção de uma sociedade justa, implicitamente, o constituinte já preconizava a construção de uma sociedade igualitária, uma vez que não é possível a construção de uma sociedade justa sem a observância da igualdade.

Em relação à igualdade em matéria tributária, Tipke a extrai, também, da própria ideia de justiça. O mestre alemão afirma que a justiça tributária é deduzida da regra geral da igualdade, que, por sua vez, é uma concepção básica de justiça. ${ }^{151}$

\footnotetext{
149 TAVARES, André Ramos. op., cit.,

${ }^{150}$ UCKMAR, Victor. Princípios comuns de direito constitucional tributário. Tradução de Marco Aurélio Greco. São Paulo: Revista dos Tribunais, EDUC, 1976, p. 53.

${ }^{151}$ TIPKE, Klaus. Op. cit., p. 191.
} 
Em estudo específico sobre a justiça fiscal, Tipke afirma que esta é o valor supremo do Estado de Direito dependente de impostos e, ao mesmo tempo, o valor supremo da comunidade de contribuintes. O princípio da igualdade exige que carga tributária total seja igualmente distribuída entre os cidadãos. ${ }^{152}$

Maurice Duverger também entende que a distribuição da carga fiscal por meio dos impostos deve ser a mais equitativa possível, uma vez que é precisamente por meio do imposto que se assegura a repartição da carga fiscal e, igualmente, é a maneira mais democrática. ${ }^{153}$

A distribuição igualitária da carga fiscal entre os cidadãos obedece à mesma máxima do princípio da igualdade, isto é, de tratamento igual para os iguais e tratamento diferenciado para os diferentes; no caso da carga fiscal, os mais ricos devem arcar com uma parcela maior da carga fiscal, enquanto os mais pobres devem arcar com uma parcela menor da carga. É esse o sentido da expressão capacidade contributiva, ou seja, quem tem mais capacidade contributiva paga mais e quem tem menos capacidade de contribuir paga menos.

Em nosso ordenamento jurídico, o princípio da capacidade contributiva está expressamente previsto no art. $145, \S 1^{\circ}$.

\footnotetext{
“Art. 145. A União, os Estados, o Distrito Federal e os Municípios poderão instituir os seguintes tributos:

(...)

$\S 1 .^{\circ}$ - Sempre que possível, os impostos terão caráter pessoal e serão graduados segundo a capacidade econômica do contribuinte, facultado à administração tributária, especialmente para conferir efetividade a esses objetivos, identificar, respeitados os direitos individuais e nos termos da lei, o patrimônio, os rendimentos e as atividades econômicas do contribuinte."
}

A fim de alcançar os objetivos propostos neste estudo, vejamos como se dá a interação da capacidade contributiva com a indução tributária, uma vez que neste campo se encontram as maiores discussões.

Visto que a capacidade contributiva é corolário do princípio da igualdade, é importante, agora, fazermos algumas considerações sobre o conteúdo jurídico deste princípio. Assim, o princípio da igualdade, por si só, não apresenta maiores resultados, porque, sozinho, é tido como vazio. É necessário que se tenha algum elemento para

152 TIPKE, Klaus; e YAMASHITA, Douglas. Justiça Fiscal e princípio da capacidade contributiva. São Paulo: Malheiros Editores, 2002, p. 18.

${ }^{153}$ DUVERGER, Maurice. Hacienda pública. Traducción de Enrique Bagaria Perpiná. $2^{\mathrm{a}}$ ed., Barcelona: BOSCH, Casa Editorial S.A., 1980, p. 100. 
comparar, porque, caso não haja algum outro elemento para testar, não há como dizer se este é igual àquele, ou se este é diferente daquele. Dessa forma, precisamos, no mínimo, de dois elementos concretos para verificar se um é igual ao outro, e em que medida são iguais.

Importante, desde já, relembrarmos o alerta que fez Tipke, em relação à igualdade e à identidade. Afirmara o autor que identidade não se confunde com igualdade, visto que igualdade é sempre relativa. O completamente igual é idêntico, e o princípio da igualdade prevê tratamento relativamente igual, não idêntico. Nesse sentido, ressalta a importância da adequada escolha do elemento de comparação, que, obrigatoriamente, deve ser um critério concreto de comparação do motivo ou da valoração que constituiu o fundamento da lei. ${ }^{154}$

Em estudo dedicado integralmente ao conteúdo jurídico do princípio da igualdade, Celso Antonio Bandeira de Mello afirma que por meio do princípio da igualdade, o que a ordem jurídica firma é a impossibilidade de desequiparação fortuita ou injustificada. ${ }^{155}$ Assim, é necessário que haja correlação lógica entre o critério desigualador e a desigualdade de tratamento. Em tal contexto, apenas um critério que se oriente pelos interesses prestigiados no ordenamento constitucional é que seria validamente aceito como elemento de discriminação. ${ }^{156}$

É imperioso, portanto, que o legislador, quando da elaboração da lei, eleja critérios constitucionalmente válidos para efetuar a discriminação. De vital importância, também, é que, posteriormente, o aplicador da lei, o Poder Executivo por meio do Fisco, também deve obedecer à igualdade, ou seja, é fundamental que haja igualdade na aplicação da lei, e não apenas na sua criação. ${ }^{157}$

O princípio da capacidade contributiva, decorrente da igualdade, ainda nos remete a outras duas ideias fundamentais, que são a proibição do confisco e o respeito ao mínimo existencial. É o que Ricardo Lobo Torres chama de limitação constitucional quantitativa, mediante a qual a tributação, com base na capacidade contributiva, pode gravar a riqueza de cada cidadão, desde que não seja excessiva, ou seja, não pode aniquilar

\footnotetext{
154 TIPKE, Klaus. Princípio de igualdade e ideia de sistema no direito tributário. In Direito Tributário: estudos em homenagem ao Prof. Ruy Barbosa Nogueira. Coordenador Brandão Machado. São Paulo: Saraiva, 1984, p. $515-540$.

${ }^{155}$ MELLO, Celso Antonio Bandeira de. Conteúdo jurídico do princípio da igualdade. $3^{\mathrm{a}}$ ed., São Paulo, Malheiros Editores, 2009, p. 18.

${ }^{156}$ Ibidem, p. $42-43$.

${ }^{157}$ TIPKE, Klaus. A necessidade de igualdade na execução das leis tributárias. In SCHOUERI, Luís Eduardo (coord.). Direito tributário, Vol. I - Homenagem a Alcides Jorge Costa. São Paulo: Quartier Latin, 2003, p. 361- 374 .
} 
a própria fonte de riqueza. ${ }^{158}$ A norma que veda a utilização do tributo com efeito de confisco está expressamente prevista no art. 150, IV, CF/88.

Dessa mesma ideia e em simetria com ela, decorre que a tributação não pode afetar o mínimo necessário para a sobrevivência do cidadão e da sua família, em condições compatíveis com a dignidade humana. Torres sintetiza essa harmonização de preceitos ao afirmar que, quando se trata de vedação de confisco, impede-se que a tributação vá além, ou ultrapasse a capacidade contributiva, porém da garantia ao mínimo existencial, infere-se que não pode existir tributação aquém, abaixo da aptidão para contribuir. ${ }^{159}$

Segundo Misabel Derzi, a vedação de confisco, art. 150, IV, tem nítida relação com o princípio da capacidade contributiva, art. $145, \S 1^{\circ}$, no entanto, não se confundem. Afirma a autora que ambos os princípios têm origem na capacidade econômico-financeira do contribuinte, ou melhor, na impossibilidade de se exceder a força econômica dele. $\mathrm{O}$ primeiro prevê uma norma que garante o direito à propriedade em termos absolutos, possui um sentido amplo, enquanto o segundo, necessariamente, além de impedir o confisco, obriga à proporcionalidade, à graduação igual, vinculando-se à justiça tributária. ${ }^{160}$

A relação entre a capacidade contributiva e a vedação do uso de tributo com efeito de confisco reflete-se na impossibilidade de exceder a força econômica do contribuinte.

Feitas tais considerações, resta o problema de como compatibilizar a capacidade contributiva com a extrafiscalidade. Vimos, no capítulo anterior, que a tributação indutora é o uso dos tributos com finalidade precipuamente não fiscal, isto é, o objetivo primário da norma não seria a arrecadação, mas, sim, a indução comportamental. Ocorre que, como esclarece Schoueri, normas tributárias indutoras não perdem a sua característica de serem tributárias, simplesmente por estarem servindo de instrumento do Estado para indução comportamental. Portanto, elas continuam devendo obediência aos limites próprios, princípios e regras do subsistema tributário. ${ }^{161}$

Francesco Moschetti, em estudo sobre a capacidade contributiva, aborda especificamente a observância desta na imposição extrafiscal, alerta que a legitimidade da tributação extrafiscal não pode ser entendida de forma ilimitada e a discriminação deve ser

\footnotetext{
158 TORRES, Ricardo Lobo. A legitimação da capacidade contributiva e dos direitos fundamentais do contribuinte. In SCHOUERI, Luís Eduardo (coord.). Direito tributário, Vol. I - Homenagem a Alcides Jorge Costa. São Paulo: Quartier Latin, 2003, p. 429- 456.

159 Ibidem.

${ }^{160}$ DERZI, Misabel. Em nota de atualização na obra: BALEEIRO, Aliomar. Limitações constitucionais ao poder de tributar. $7^{\text {a }}$ ed., Rio de Janeiro: Forense, 2006, p. 574.

${ }^{161}$ SCHOUERI, Luís Eduardo. Normas tributárias..., op. cit., p. 34.
} 
sempre fruto de uma correta interpretação constitucional. O mestre italiano fornece quatro elementos que, em seu entendimento, sendo seguidos, obedecerão à Constituição: $a$ ) obrigatoriedade de os atos gravados serem situações indicativas de capacidade econômica; b) a qualificação de capacidade econômica, em termos capacidade contributiva, deve resultar de uma interpretação sistemática da Constituição; não basta, portanto, a escolha de um interesse qualquer pelo legislador ordinário, para que seja legítima a utilização extrafiscal, é necessário eleger um interesse coletivo que se enquadre nas "ideias guias" da Constituição. ${ }^{162}$

O mesmo autor ainda faz um alerta que nos parece sobremaneira importante, de que o imposto deve ser coerente com a sua natureza, o que, por consequência, impede que seja usado como instrumento de sanção. Caso o ato ilícito ou danoso seja "repreendido" com um imposto, paradoxalmente, legitima-se o fato que se queria impedir. ${ }^{163}$

Apesar de Moschetti ter dissertado com base no ordenamento jurídico italiano, parece-nos que as suas considerações e as suas conclusões são perfeitamente aceitáveis, igualmente, em nosso sistema jurídico.

Nesse contexto e com base nas considerações feitas anteriormente, é chegado o momento de enfrentarmos a questão da capacidade contributiva quando a imposição tributária incidir sobre um fato que gere poluição. Dito de outra forma, como conciliar o princípio da capacidade contributiva com a tributação da poluição?

Com fundamento nas ideias acima expostas, vimos que a capacidade contributiva possui dois limites quantitativos: um máximo, consubstanciado na vedação do confisco, e outro mínimo, que garante o mínimo existencial do cidadão. Assim, num primeiro aspecto, podemos afirmar que se o tributo ecológico atende a esses dois limites, esse tributo é constitucional, visto que não feriu os limites quantitativos da capacidade contributiva.

Contudo, não são esses os únicos limites a serem observados. Da mesma forma, vimos que, na tributação indutora, o legislador ordinário não é livre para eleger todo e qualquer fato que entenda como passível de ser tributado. É necessário que ele, legislador, observe os preceitos constitucionais, e a defesa do meio ambiente é um desses preceitos.

${ }^{162}$ MOSCHETTI, Francesco. El principio de la capacidad contributiva. In AMATUCCI, Andrea (coord.). Tratado de derecho tributario. Tomo Primero - El derecho tributario y sus fuentes. Bogotá - Colombia: Editorial Temis S.A., p. 240 - 284.

${ }^{163}$ Ibidem. 
Vamos além: o fato de um tributo ecológico não ter como foco central um índice que meça, diretamente, as tradicionais fontes de riqueza (renda, patrimônio ou consumo), não significa que esse tributo é inconstitucional. Partindo da premissa de que o tributo ecológico tem como fundamento de validade a defesa do meio ambiente, o legislador pode escolher um índice que vise a promover ou a resguardar esse direito constitucionalmente previsto, e apenas reflita uma riqueza. Assim, o tributo ecológico não precisa medir diretamente a riqueza, pode apenas refleti-la.

Fernández Orte se manifesta-se no mesmo sentido e assevera que, não obstante as emissões ${ }^{164}$ não representarem manifestação direta alguma de riqueza, elas são consequências da realização de atividades que, indiretamente, refletem capacidade econômica. ${ }^{165}$

Cláudia Dias Soares alerta que o rendimento não pode ter, nas atuais sociedades, o mesmo papel omnicompreensivo que tinha no passado (cerca de trinta ou quarenta anos atrás) na medida da posição econômico-social do contribuinte. Os comportamentos que desencadeiam custos ambientais, os atos de consumo ou de fruição de recursos naturais, atualmente, são considerados como índices reveladores de capacidade contributiva. ${ }^{166}$

Mas, igualmente, Cláudia Soares entende que a tributação da emissão de poluentes não representa, por si só, capacidade contributiva, o que poderia dar ensejo à violação dos princípios da igualdade e da justiça tributária. No entanto, alerta a autora que esse fato não ocorre de forma isolada, mas é consequência do desenvolvimento de uma atividade econômica, a qual manifesta capacidade econômica. ${ }^{167}$

No entanto, alerte-se que não é toda e qualquer espécie de contaminação que pressupõe uma riqueza. Existem condutas humanas básicas que geram contaminação, mas não geram riqueza alguma. Assim, como a tributação ecológica precisa respeitar a capacidade contributiva e essa pressupõe, ao menos, o reflexo de um índice de riqueza, nessas ações humanas, não há que se falar em tributação. ${ }^{168}$

\footnotetext{
${ }^{164} \mathrm{O}$ autor se utiliza deste termo genérico para indicar a poluição atmosférica, aquática, sobre o solo ou mesmo advinda de ruídos.

${ }^{165}$ ORTE, J. Fernandez. La tributación medioambiental, teoría e prática. Navarra - Espanha: Editorial Aranzadi, S.A. 2006, p. 156

${ }^{166}$ SOARES, Cláudia Alexandra Dias. O imposto ecológico - contributo para o estudo dos instrumentos económicos de defesa do ambiente. Coimbra: Coimbra, 2001, p. 317.

${ }^{167}$ Ibidem.

${ }^{168}$ ALABERN, Juan Enrique Varona. Extrafiscalidad y dogmática tributaria. Madrid: Marcial Pons, 2009, p. 150.
} 


\subsubsection{Livre Concorrência}

Partindo da ideia de um sistema jurídico, composto por um conjunto de subsistemas, podemos afirmar que os subsistemas tributário e econômico caminham paralelamente.

Nesse sentido, assim como fez com o subsistema tributário, a Constituição também assegurou, de forma expressa, princípios gerais que regem a atividade econômica, art. 170, CF/88:

\footnotetext{
"Art. 170. A ordem econômica, fundada na valorização do trabalho humano e na livre iniciativa, tem por fim assegurar a todos existência digna, conforme os ditames da justiça social, observados os seguintes princípios:

(...)

IV - livre concorrência;"
}

O princípio da livre concorrência tem especial correlação com a tributação em razão dos próprios efeitos desta. Como já vimos anteriormente, se, no passado, à tributação não era permitido interferir nos mercados, porque a neutralidade tributária era entendida no sentido do total distanciamento do Estado em relação àquele. E, ainda, prevalecia a falsa ideia de que o próprio mercado seria capaz de garantir a total e perfeita concorrência mercadológica. Atualmente, o pensamento é outro e, ao Estado, foi dado o dever de defender o mercado.

Além de a livre concorrência ter sido elencada como um princípio geral da atividade econômica, o constituinte ainda previu a utilização do tributo como instrumento de defesa da concorrência de forma expressa, no art. 146-A, CF/88. E, igualmente, previu tratamento diferenciado e favorável para microempresas e empresas de pequeno porte, art. 146, III, d, CF/88.

Dessa forma, consciente da possibilidade de os tributos gerarem efeitos sobre a economia, o constituinte optou por usar o tributo como um mecanismo em prol do mercado, como instrumento de combate às distorções que o mercado pudesse vir a ocasionar. É esse o sentido imediato que podemos extrair dos art. 146, III, e art. 146-A da $\mathrm{CF} / 88$.

Cumpre destacar que a ordem econômica, insculpida no art. 170, CF/88, tem como seus fundamentos, dois fundamentos da própria República Federativa brasileira, art. $1^{\circ}, I V$, quais sejam, a valorização do trabalho e a livre iniciativa. Contudo, o art. 170 explica que a ordem econômica com esses fundamentos tem como objetivo assegurar a 
todos existência digna conforme os ditames da justiça social. Ainda, o mesmo dispositivo constitucional traz uma série de princípios que devem ser observados na busca desse objetivo constitucionalmente previsto. Desse modo, a livre concorrência é apenas um desses princípios que, obrigatoriamente, se deve harmonizar com os demais.

Assim sendo, a livre iniciativa não se confunde com a livre concorrência. $\mathrm{O}$ princípio da livre iniciativa deve ser entendido como a possibilidade de atuação particular no domínio econômico, sem obstáculos do poder público. Trata-se de parcela de liberdade, desdobrada como liberdade ao livre exercício de atividade econômica. ${ }^{169}$

A livre iniciativa diz respeito ao ingresso no mercado, a livre escolha para exercer qualquer atividade econômica. Conforme Tercio Ferraz Júnior, a livre iniciativa deve ser entendida como um direito fundamental de concorrer e de atuar criativamente no jogo livre de mercado. ${ }^{170}$

Modesto Carvolhosa, em estudo sob a égide da Constituição de 1969, mas que em nada impede expormos suas lições, afirma que a livre iniciativa é um direito fundamental, que deve atender aos interesses da coletividade, por meio da sua vinculação aos fins constitucionalmente propostos à Ordem Econômica, desenvolvimento nacional e justiça social. ${ }^{171}$

Eros Grau, em estudo sob a égide da nossa atual Carta, manifesta-se no sentido da necessária vinculação entre livre iniciativa e o socialmente valioso, uma vez que a livre iniciativa não pode ser entendida como expressão individualista. Para Grau, o trabalho humano deve ser valorizado. A livre iniciativa é tomada pela Constituição de forma singela, em relação ao trabalho humano. ${ }^{172}$

A livre concorrência, em tal contexto, tem sua fundamentação na ideia de liberdade. Todavia, diferentemente dos séculos passados, notadamente do século XIX, no qual o indivíduo exercia a sua garantia de liberdade para defende-se dos desmandos do soberano, atualmente a liberdade surge com um sentido socialmente comprometido. Dessa forma, a livre concorrência não garante um mercado livre, sem interferência do Estado,

\footnotetext{
${ }^{169}$ BOMFIM, Diego. Tributação e livre concorrência. São Paulo: Saraiva, 2011, p. 173.

${ }^{170}$ FERRAZ JUNIOR, Tercio Sampaio. Obrigação tributária acessória e limites de imposição: razoabilidade e neutralidade concorrencial do Estado. In: Princípios e limites da tributação. Coord. Roberto Ferraz. São Paulo: Quartier Latin, 2005, p. 715 - 735 (p. 726).

171 CARVALHOSA, Modesto. Direito econômico: obras completas. São Paulo: Editora Revista dos Tribunais, 2013, p. 686.

${ }^{172}$ GRAU, Eros Roberto. A ordem econômica na Constituição de 1988. 13 $13^{\mathrm{a}}$ ed., São Paulo: Malheiros Editores, 2008, p. 201.
} 
mas preconiza que o Estado deva buscá-la, para que alcance um bem maior, a existência digna de todos. ${ }^{173}$

Em igual sentido, adverte André Ramos Tavares que a livre concorrência não exige uma absoluta abstenção do Estado, ao contrário, está a impor uma intervenção deste, no sentido de garantir que, no mercado, permaneça a liberdade geral, que poderia ser tolhida por algum agente econômico, ${ }^{174}$ de forma intencional, ou mesmo por alguma medida do Governo que viesse a causar tal efeito, quiçá por algum tipo de crise econômica internacional.

Dessa maneira, podemos chegar a duas conclusões: a primeira é que o princípio da livre concorrência deriva do princípio da livre iniciativa. E a segunda, de que tanto a livre iniciativa quanto a livre concorrência decorrem, em última análise, do princípio da igualdade. Com o primeiro princípio, garante-se a qualquer indivíduo o livre acesso ao mercado, enquanto o segundo, garantem-se a todos os presentes no mercado as mesmas condições de atuação.

Feitas tais considerações, vejamos como um tributo ecológico poderia afetar a livre concorrência ou mesmo a livre iniciativa. Supondo que um Estado crie um tributo ecológico, com o intuito de internalizar as externalidades negativas dos agentes econômicos atuantes no seu mercado, pode até ser que ele consiga assegurar a livre concorrência, uma vez que os agentes econômicos que estavam em desvantagem por possuírem maiores custos, já que os outros não internalizam alguns custos, agora passem a atuar em patamar de igualdade ou até mesmo de ligeira vantagem. Nesse caso hipotético, parece-nos que não teríamos afronta alguma em relação ao princípio da livre concorrência, pelo contrário, estaríamos garantindo e fortalecendo a livre concorrência.

No entanto, tomando como base esse mesmo exemplo, teríamos o problema do qual nos faz o alerta Gerd Rothmann, em estudo específico sobre a livre concorrência. Segundo o autor, teríamos problemas com a competitividade internacional, porque, em primeiro lugar, os produtos nacionais ficariam mais caros, quando comparados com produtos de países que não tenham tipo algum de tributo ou custo parecido. À vista disso, os tributos ecológicos podem gerar o efeito indesejável de onerar as exportações e de incentivar as importações, já que esses produtos poderiam tornar-se mais baratos.

\footnotetext{
${ }^{173}$ SCHOUERI, Luís Eduardo. Direito tributário. op. cit., p. 331.

${ }^{174}$ TAVARES, André Ramos. Direito constitucional econômico. $3^{\text {a }}$ ed., Rio de Janeiro: Forense; São Paulo: MÉTODO, 2011, p. 258.
} 
De fato, esse é um efeito que pode ocorrer e tem feito vários países deixarem de implantar as chamadas reformas fiscais ecológicas. Apesar de a própria OCDE reconhecer esse problema, afirma existirem estudos capazes de mostrar que, no cenário do mercado internacional, essa questão não gera impactos tão significativos. ${ }^{175}$

No entanto, preocupados com os efeitos que possam ser causados caso haja a efetiva implantação do tributo ecológico, a OCDE indica cinco principais opções políticas, caso o Estado perceba que realmente irá ter perda de competitividade internacional: a) um mecanismo de "reciclagem de receitas", que consiste basicamente em devolver para a empresa, integral ou parcialmente, a receita auferida com o tributo, com o intuito de que ela invista em pesquisa e desenvolvimento de tecnologia contra a poluição ou para economia de energia; b) isenções fiscais para atividades, setores ou produtos específicos; c) redução de alíquotas do tributo para determinados setores, produtos ou insumos; d) ajustes de tarifas alfandegárias, com o intuito de não permitir que produtos estrangeiros, sem o tributo ecológico, na origem, ingressem no mercado nacional mais barato; e) coordenação internacional. ${ }^{176}$

Nota-se que, de fato, a questão é bastante complexa e não há como afirmar que, adotada uma medida, o problema será solucionado. No entanto, também não é uma questão sem solução. A ideia da efetiva reforma fiscal ecológica, consiste, basicamente, em introduzir o elemento ecológico no subsistema tributário e, com isso, evitar a perda de arrecadação, mas, ao mesmo tempo, desonerar outras fontes de recursos, com o intuito de gerar ganho de eficiência nos parece a melhor solução. Ocorre que essa, porém, é uma alternativa substancialmente mais complexa, mas que, aparentemente, teria o poder de solucionar esse tipo de problema de forma mais sistêmica.

Outra questão que também merece atenção é a do eventual valor do tributo, porque, não é possível, igualmente, instituir um tributo tão elevado que impeça outros agentes econômicos de ingressarem no mercado, porque se estaria impedindo, dessa maneira, a livre iniciativa.

\footnotetext{
${ }^{175}$ BARDE, Philippe. Green tax reforms in OECD countries: na overview. In II Taller Regional de Política Fiscal y Medio Ambiente en America Latina y el Caribe, Santigago de Chile, 27 de enero de 2004. www.oecd.org/env/taxes acessado em 25.9.2012.

${ }^{176}$ Ibidem.
} 


\subsubsection{Defesa do meio ambiente}

Como já vimos, a defesa do meio ambiente está prevista em diversos dispositivos constitucionais, expressa e implicitamente. Apenas, para recordar, do enunciado do art. 225, da $\mathrm{CF} / 88$, podemos extrair várias considerações importantes e delas vejamos apenas duas: a primeira dela é que a vincula o meio ambiente ecologicamente equilibrado como essencial à sadia qualidade de vida. A segunda é a que impõe o dever de preservar e defender o ambiente ecologicamente equilibrado a todos, sociedade e Poder Público, para as presentes e futuras gerações, enquanto o art. 170, VI, impõe um dever à ordem econômica, o de observar a defesa do meio ambiente, inclusive mediante tratamento diferenciado conforme o impacto ambiental dos produtos e serviços e de seus processos de elaboração e prestação.

Como o Direito Tributário e o Direito Econômico, o Direito Ambiental também é considerado didaticamente autônomo. Assim, apesar de possuir princípios e regras próprias, não pode ser interpretado de maneira isolada e há de ser entendido em conformidade com todo o sistema constitucional, por consequência, com todos os subsistemas que dele derivam. Nesse contexto, é importante verificarmos como se dá a integração sistêmica entre o meio ambiente, a ordem econômica e a ordem tributária.

Não convêm, tampouco interessa, para os propósitos deste trabalho, analisarmos todos os princípios de Direito Ambiental, da mesma forma como fizemos em relação à ordem tributária e à ordem econômica. Iremos apenas debruçar-nos sobre o princípio que entendemos ser o de maior afinidade com a tributação ecológica.

Dentre os vários princípios de Direito Ambiental, entendemos que o princípio do poluidor - pagador é o que mais influencia os tributos ecológicos. Apesar do que o enunciado do princípio possa sugerir, este princípio não se limita a trazer a responsabilização civil do agente poluidor, por ser óbvio que ela existe, mas não esgota o seu alcance aí, vai mais além.

O conteúdo normativo desse princípio, segundo Alexandre Aragão, expressa-se na realização da prevenção, da precaução e da equânime redistribuição dos custos das medidas públicas. ${ }^{177}$

${ }^{177}$ ARAGÃO, Alexandra. Direito constitucional do ambiente da União Europeia. In: Direito constitucional ambiental brasileiro. José Joaquim Gomes Canotilho e José Rubens Morato Leite (org.). $3^{a}$ ed., São Paulo: Saraiva, 2010, p. $32-76$, (p. 69). 
Cristiane Derani é enfática ao afirmar que o princípio do poluidor - pagador visa à internalização dos custos relativos externos de deterioração ambiental. Por esse princípio, o causador da poluição arca com os custos necessários à diminuição, eliminação ou neutralização do dano. ${ }^{178}$

Ricardo Lobo Torres entende que o princípio do poluidor - pagador está ligado à ideia de internalização de eventuais prejuízos ambientais, sem a qual seria repassado para terceiros o ônus necessário para cobrir os riscos ambientais. $\mathrm{O}$ autor afirma, ainda, que este princípio está vinculado ao princípio da justiça em razão da impossibilidade de o poluidor, que já se apropria do lucro de sua atividade poluente, externalizar negativamente a poluição que pratica, isto é, o poluidor não pode transferir um custo que deveria ser seu para a sociedade. ${ }^{179}$

Alexandra Aragão ainda traz algumas observações importantes relacionadas ao princípio do poluidor - pagador. Afirma a autora que, se aos poluidores somente forem dadas as alternativas: a) deixar de poluir ou b) ter que suportar um custo econômico em favor do Estado, eles terão de necessariamente, fazer os seus cálculos econômicos de modo a escolher a opção mais vantajosa: a) acatar as disposições que desestimulam a poluição e tomar todas as medidas necessárias a evitá-la, ou b) manter a produção em padrões e em níveis tais que ainda seja economicamente rentável suportar os custos que isso acarreta. ${ }^{180}$

Entende a autora que, estabelecido um valor proporcional, para atingir o valor da poluição que os agentes emitem, chegar-se-ia a uma situação social ótima, pois haveria redução da poluição a um nível aceitável e, simultaneamente, haveria recursos para criação de fundos de combate à poluição. No entanto, ela mesma reconhece que é difícil encontrar esse valor, o que poderia gerar instabilidades, em razão das constantes mudanças. Conclui, afirmando que, como o princípio do poluidor - pagador é, essencialmente, um princípio que visa a proteger o meio ambiente, e não apenas responsabilizar, ressarcir a sociedade, tal comportamento estaria em conformidade com o princípio. ${ }^{181}$

Estamos em total consonância com as ideias da autora, no que concerne ao âmbito de atuação do princípio do poluidor - pagador. O princípio não pode ser entendido, como exclusivo instrumento de responsabilização posterior. É preciso entender este princípio, também, como um elemento que previna a poluição.

\footnotetext{
${ }^{178}$ DERANI, Cristiane. Direito ambiental econômico. $3^{\text {a }}$ ed., São Paulo: Saraiva, 2008, p. 143.

179 TORRES, Ricardo Lobo. Princípios e teoria geral do direito tributário ambiental. In: TÔRRES, Heleno Taveira (org.). Direito tributário ambiental. São Paulo: Malheiros Editores, 2005, p. 21 - 54, (p. 27).

${ }^{180}$ Op. cit., p. 69.

${ }^{181}$ Ibidem.
} 
No entanto, em relação ao exemplo dado, é preciso que se leve em consideração outra questão. Como já afirmamos ao longo do trabalho, apesar de o Direito Ambiental ter autonomia didática cientifica, quando se forem analisar casos concretos, é preciso que se analise todo o sistema jurídico.

Nesse contexto, no exemplo acima fornecido, são superadas as complexidades de se encontrar um adequado valor para efetuar a cobrança. Como se está lidando com atividade econômica, é preciso que, obrigatoriamente, se leve em consideração a garantia da livre concorrência. Se houver um ou alguns poucos agentes economicamente fortes, que mantenham o menor valor cobrado, por certo período de tempo, conservando seu preço no patamar mais baixo, é possível que essa cobrança gere um efeito concorrencial perverso sobre aquele setor, inclusive, pode inviabilizar a permanência no mercado de alguns agentes, ou até mesmo de parte daquele setor econômico.

Portanto, é imprescindível que, quando se for criar e cobrar tributos como estes, se atente para os princípios da ordem econômica, notadamente o da livre concorrência. Da mesma forma, a possibilidade de tratamento diferenciado que prevê o art. 170, VI, da CF/88, caso seja implantado, não pode ser tão exagerado, que se chegue ao ponto de inviabilizar a própria atividade econômica e fazer com que alguns poucos agentes permaneçam no mercado.

\subsubsection{Praticabilidade}

A praticabilidade decorre da qualidade de ser praticável, de que algo pode ser praticado. É atributo que está intrinsecamente ligado ao Direito, pois, este somente atua no campo das possibilidades reais. Assim, a praticabilidade também é conhecida como praticidade, pragmatismo ou factibilidade, e deve ser entendida, em seu conteúdo jurídico, como o conjunto de técnicas que visam a viabilizar a adequada execução do ordenamento jurídico. $^{182}$

Segundo Misabel Derzi, o princípio da praticabilidade não decorre de uma norma escrita e expressa, mas, sim, do próprio ordenamento jurídico. Assim sendo, trata-se de um princípio geral de economicidade e exequibilidade, que inspira o direito de maneira

${ }^{182}$ COSTA, Regina Helena. Praticabilidade e justiça tributária, exequibilidade de lei tributária e direitos dos contribuintes. São Paulo: Malheiros Editores, 2007, p. 52-53. 
integral. E engloba todos os meios e técnicas utilizáveis com o objetivo de tornar simples e viável a execução das leis, dado que é pressuposto da lei a sua aplicação e imposição. ${ }^{183}$

Eduadro Maneira entende que a praticabilidade é, na essência, um atributo da própria legalidade, pois a lei deve ser exequível e de possível aplicação prática. Por tal motivo, são utilizadas técnicas de simplificação que possibilitem alcançar realidades complexas. ${ }^{184}$

Tipke, ao dissertar sobre a justificação do grupo de normas simplificadoras, para ele, significa a necessidade de as normas serem práticas. Afirma que elas possuem especial relevância quando a administração lida com casos massificados, como é o caso da administração tributária. Essas normas devem possibilitar ou suavizar a "operação de massa" da imposição e devem impedir a hipercomplicação e intramitabilidade das leis ou despesas administrativas desproporcionadas. A simplificação, em última análise, favorece a própria igualdade, uma vez que leis que não são práticas não podem ser uniformemente executadas. $^{185}$

Humberto Ávila também se manifesta na mesma linha de pensamento. Para o autor, a justificativa da padronização ou das normas com finalidade simplificadora, justificam-se em razão da suposta impossibilidade ou extrema onerosidade para fiscalizar cada operação individual. Nesse caso, no uso desse tipo de técnica, perde-se em justiça individual, mas opta-se pela efetivação da igualdade geral. ${ }^{186}$

César García Nóvoa também defende que a aplicação da simplificação e da praticabilidade resulta em benéfico de uma efetiva aplicação do sistema tributário que garanta a generalização, na medida em que cria as condições para que todos contribuam. 187

Nesse âmbito, o Estado pode utilizar inúmeros instrumentos para tentar alcançar a praticabilidade, tais como as abstrações generalizantes, por meio de presunções,

\footnotetext{
${ }^{183}$ DERZI, Misabel. Direito tributário, direito penal e tipo. $2^{\mathrm{a}}$ ed., São Paulo: Revista dos Tribunais, 2007, p. 139.

${ }^{184}$ MANEIRA, Eduardo. Praticidade tributária. In: TÔRRES, Heleno Taveira (coord.). direito tributário e ordem econômica, homenagem aos 60 anos da ABDF. São Paulo: Quartier Latin, 2010. p. 379-396 (p. 381). ${ }^{185}$ TIPKE, Klaus. Direito tributário. op. cit., p. 232.

186 ÁVILA, Humberto. Teoria da igualdade tributária. $2^{\mathrm{a}}$ ed., São Paulo: Malheiros Editores, 2009, p. 88 89.

${ }^{187}$ NOVOA, César García. El reto de la simplificacion de los sistemas tributarios. In: PIRES, Adilson Rodrigues; e TÔRRES, Heleno Taveira (organizadores). Princípios de direito financeiro e tributário Estudos em homenagem ao Professor Ricardo Lobo Torres. Rio de Janeiro: Renovar, 2006, p. 319 - 344 (p. 332).
} 
ficções e indícios, conceitos jurídicos indeterminados, cláusulas gerais, normas em branco, padronizações, quantificações. ${ }^{188}$

Portanto, não há dúvida de que o Poder Público, em nome da praticabilidade, pode valer-se de instrumentos que relativizem a capacidade contributiva individual, em prol da geral, mas não tem liberdade ilimitada. O Estado deve obedecer aos limites extraídos do próprio ordenamento jurídico, analisado de forma sistemática.

Dessarte, Regina Helena Costa fornece uma série de limites à praticabilidade, cujo fundamento é o próprio texto constitucional: a) como a veiculação dos instrumentos por meio de lei; b) a observância da capacidade contributiva, e, apenas, subsidiariamente a utilização de técnicas presuntivas, pois, apenas nos casos de impossibilidade concreta de se provar o fato tributável é que as presunções podem ser utilizadas; c) impossibilidade da adoção de presunções absolutas ou ficções para criações de obrigações tributárias, pois é fundamental que o contribuinte tenha o direito de fazer prova em contrario; d) transparência na adoção de técnicas presuntivas; e) justificação das normas de simplificação; f) caráter opcional e benéfico aos contribuintes dos regimes normativos de simplificação ou padronização, dentre outras. ${ }^{189}$

Todas essas limitações, como se percebe, têm seus fundamentos de validade facilmente extraídos do ordenamento jurídico constitucional. São limitações que visam a proteger o contribuinte da incessante voracidade fiscal e, além disso, tenta impedir que o Fisco cometa abusos, e, ainda, visa a garantir a certeza e a segurança jurídica das relações entre o contribuinte e o Fisco.

Assim, em sistemas complexos, que necessitam da praticabilidade, precisamente, para poder funcionar, é fundamental a imposição de limites que visem a combater os abusos. Caso contrário, pode o Estado querer transferir todo o ônus da fiscalização e da cobrança para o próprio contribuinte.

Nesse sentido, no que tange ao nosso sistema, é importante destacarmos a necessidade de uma urgente e racional reforma, mas uma reforma no sentido de racionalizar o sistema, inclusive no que tange às obrigações acessórias, pois, recente pesquisa do Banco Mundial, mostrou que uma empresa instalada no Brasil, para cumprir com todas as suas obrigações tributárias, gasta em média 2600h (duas mil e seiscentas horas). A quantidade média de horas gastas pelos países da América Latina e Caribe é de 382h (trezentas, oitenta e duas horas), enquanto os países membros da OCDE gastam, em

\footnotetext{
${ }^{188}$ COSTA, Regina Helena. Praticabilidade... op. cit., p. 158.

${ }^{189}$ Ibidem, p. $216-219$.
} 
média, 186h (cento e oitenta e seis horas). No âmbito mundial, de um total de 183 países, o Brasil fica em 150. ${ }^{190}$

Isso significa que uma empresa instalada no Brasil gasta mais de treze vezes o número de horas para quitar todas as suas obrigações fiscais que uma empresa instalada em um dos países membros da OCDE, e mais de seis vezes o número de horas que uma empresa instalada em algum país vizinho, América Latina e Caribe.

Todavia, podemos concluir que não é o fato, por si só, de existirem normas simplificadoras para o Fisco, muitas vezes transferindo suas responsabilidades para os contribuintes, notadamente as de apuração do tributo e de recolhimento/cobrança, sob o argumento da praticabilidade, que realmente vai tornar o sistema mais simples, prático e eficiente.

Pelo contrário, é preciso atentar que, sob o argumento da praticabilidade, o Fisco pode querer transferir um ônus que era seu para o contribuinte, fazendo com que este tenha um custo mais elevado ainda, pois gastará mais tempo para poder cumprir suas obrigações e, fatalmente, irá aumentar, também, o número de obrigações acessórias a serem observadas.

Nesse contexto, em relação à tributação ecológica, como pudemos observar no tópico anterior, o cálculo para se chegar a um valor correto de quanto aquele indivíduo, especificamente, deveria pagar, em razão da deterioração do bem ambiental, é extremante difícil. Ainda não existem parâmetros concretos, nem fórmulas prontas. Trata-se, portanto, de um cálculo que vai depender, essencialmente, do comportamento do consumidor, do fator de elasticidade da demanda daquele bem, da participação no mercado daquele agente, entre outras, ou seja, de inúmeras variáveis que não são fáceis de serem encontradas e podem tornar um tributo ecológico extremamente complexo.

Nestes sentido, Schoueri, citando Gawel, salienta a importância de se medir a elasticidade da oferta e da demanda, já que se for inelástica, de nada adiantará um agravamento da tributação, que apenas aumentará o preço dos bens, sem modificar o consumo $^{191}$, e por consequência, os comportamentos.

Assim, insistimos na questão de ser fundamental a observância dos limites constitucionais quando o Estado queira adotar alguma medida sob o argumento da praticabilidade. E, ainda, não há que se confundir o simples fato de o Estado aumentar a

${ }^{190}$ Doing Business, 2012. Copublication of The World Bank and The International Finance Corporation.

${ }^{191}$ SCHOUERI, Luís Eduardo. Normas tributárias indutoras. Op. cit., pág. 49. 
sua arrecadação com a praticabilidade, porque esse aumento na arrecadação pode ter sido conquistado, exatamente em detrimento de direitos dos contribuintes.

\subsection{COMPETÊNCIAS}

Tradicionalmente, temos duas grandes divisões nas formas de Estado: os unitários, nos quais o poder central é a cúpula e o núcleo do poder político, e os federais, que conjugam vários centros de poder político autônomo. No entanto, modernamente, alguns estudiosos sustentam a existência de uma nova espécie, o Estado Regional, o qual é menos centralizado do que o unitário, mas sem a forte descentralização do federalismo. Seriam exemplos desse novo modelo de Estado a Espanha e a Itália. ${ }^{192}$

Assim, em um Estado Federal, a descentralização de poder entre as diversas esferas políticas é concretizada por meio de técnicas de divisão vertical do poder. A Constituição reparte, entre todos, competências, encargos e rendas. Dependendo da técnica de repartição adotada, haverá competências exclusivas, do poder central ou dos poderes subnacionais, ou locais, e competências comuns a todos eles. ${ }^{193}$

Nina Ranieri alerta que uma Federação comporta diferentes realidades ${ }^{194}$, assim, não há uma estrutura fechada. Especificamente em relação à nossa Federação, cumpre destacar que o constituinte elencou três entes autônomos - União, Estados e Municípios. Colocamos apenas três entes, pois, em nosso entendimento, o Distrito Federal é um ente híbrido, que possui tanto as competências dos Estados, quanto dos Municípios, não fica além, nem aquém destes, apenas cumula as duas competências.

\footnotetext{
“Art. 18. A organização político-administrativa da República Federativa do Brasil compreende a União, os Estados, o Distrito Federal e os Municípios, todos autônomos, nos termos desta Constituição."
}

\footnotetext{
${ }^{192}$ DALLARI, Dalmo. Elementos de teoria geral do Estado. 30ª ed., São Paulo: Saraiva, 2011, pág 251.

${ }^{193}$ RANIERI, Nina Beatriz Stoco. Teoria do Estado: do Estado de Direito ao Estado Democrático de Direito. Barueri, SP: Manole, 2013, p. 136.

194 Ibidem.
} 
Nesse contexto, competências seriam as diversas modalidades de poder que os órgãos ou entidades estatais possuem, no intuito de realizar seus encargos, isto é, suas funções, tarefas, serviços. ${ }^{195}$

Desse modo, neste tópico, iremos analisar como estão dispostas as competências tributária e ambiental e como se dá a interação entre essas duas espécies de competências.

\subsubsection{Competência tributária}

Como visto, quando se trata de competência, atribuição de poder, apenas a Constituição a pode outorgar. Portanto, as atribuições das competências tributárias, estão integral e taxativamente previstas na nossa Carta Magna e, nesse sentido, não há possibilidade de acumulação ou concorrência entre os entes.

Contudo, Schoueri noticia que a repartição de competências tributárias não é uma condição para um sistema federal. A exigência que o sistema federal impõe é em relação à autonomia financeira e ela implica a discriminação de rendas, mas não se confunde com discriminação de competências. ${ }^{196}$

Roque Carrazza, ${ }^{197}$ ao esclarecer que competência tributária é a aptidão do ente jurídico de direito público interno para criar tributo, atribui seis características à competência tributária, que nos parecem bastante esclarecedoras: a) privatividade: tem o sentido de reafirmar que cada ente tributante tem sua faixa exclusiva de competência; $b$ ) indelegabilidade: a competência não pode ser delegada a outro ente; c) incaducabilidade: mesmo que o ente não exerça a sua competência, esta não caduca com o decurso do tempo; d) inalterabilidade: o ente não pode criar ou ampliar situações que estejam previstas no texto constitucional, portanto, apenas o próprio constituinte pode alterar a competência; $e$ ) irrenunciabilidade, assim como não pode delegar e alterar a competência, o ente também não pode renunciar a tal direito; e f) facultatividade: mesmo sendo inalterável, indelegável e irrenunciável, a competência não é obrigatória, é apenas facultativa, é uma faculdade da qual dispõe o ente, que a exercerá ou não.

À vista disso, o texto constitucional, em seu art. 145, traz as espécies tributárias comuns aos três entes da nossa Federação, impostos, taxas e contribuições de melhoria.

\footnotetext{
${ }^{195}$ SILVA, José Afonso da. Direito ambiental constitucional. $8^{\mathrm{a}}$ ed., São Paulo: Malheiros Editores, 2010, p. 72.

${ }^{196}$ SCHOUERI, Luís Eduardo. Direito tributário. op. cit., p. 238.

${ }^{197}$ CARRAZZA, Roque Antonio. op. cit., p. 519.
} 


\begin{abstract}
“Art. 145. A União, os Estados, o Distrito Federal e os Municípios poderão instituir os seguintes tributos:

I - impostos;

II - taxas, em razão do exercício do poder de polícia ou pela utilização, efetiva ou potencial, de serviços públicos específicos e divisíveis, prestados ao contribuinte ou postos a sua disposição;

III - contribuição de melhoria, decorrente de obras públicas.”
\end{abstract}

Percebe-se, de uma simples análise do texto constitucional, que todos os entes da Federação detêm competência para instituir as três espécies mencionadas, impostos, taxas e contribuições de melhoria. No entanto, a União ainda detém a competência exclusiva sobre os empréstimos compulsórios, art. 148, que são tributos excepcionais, previstos para situações extraordinárias ou urgentes, e sobre as contribuições sociais, art. 149 e art. 195.

Em relação aos impostos, a Constituição tratou de forma individualizada e taxativa, e, ainda, especificou a matriz de cada um deles, em dispositivos próprios. $\mathrm{O}$ art. 153 trata dos impostos de competência da União. ${ }^{198} \mathrm{O}$ art. 155 especifica as bases tributáveis pelos Estados. ${ }^{199}$ E o art. 156 descreve os impostos dos Municípios. ${ }^{200}$

Ainda, o art. 154, I, previu a chamada competência residual, possibilidade de a União, exclusivamente, instituir impostos que ainda não tenham sido previstos no texto constitucional, desde que sejam não cumulativos e mediante lei complementar. ${ }^{201}$

Como em relação às taxas, prevalece a ideia de contraprestação, não há motivos para discriminação de competências, porque, caso o ente federado preste ou tenha posto à disposição do contribuinte serviço público, específico e divisível, ou o ente exerça o seu poder de polícia, aquele ente poderá instituir a referida taxa.

198 Art. 153. I - importação de produtos estrangeiros; II - exportação, para o exterior, de produtos nacionais ou nacionalizados; III - renda e proventos de qualquer natureza; IV - produtos industrializados; V - operações de crédito, câmbio e seguro, ou relativas a títulos ou valores mobiliários; VI - propriedade territorial rural; VII - grandes fortunas, nos termos de lei complementar.

199 Art. 155. Compete aos Estados e ao Distrito Federal instituir impostos sobre: I - transmissão "causa mortis" e doação, de quaisquer bens ou direitos; II - operações relativas à circulação de mercadorias e sobre prestações de serviços de transporte interestadual e intermunicipal e de comunicação, ainda que as operações e as prestações se iniciem no exterior; III - propriedade de veículos automotores.

200 Art. 156. Compete aos Municípios instituir impostos sobre: I - propriedade predial e territorial urbana; II transmissão "inter vivos", a qualquer título, por ato oneroso, de bens imóveis, por natureza ou acessão física, e de direitos reais sobre imóveis, exceto os de garantia, bem como cessão de direitos a sua aquisição; III serviços de qualquer natureza, não compreendidos no art. 155, II, definidos em lei complementar.

${ }^{201}$ Luis Eduardo Schoueri, na sua obra Direito Tributário, op. cit., p. 248, afirma que o constituinte, ao distribuir as competências tributárias não disse, exatamente qual é a hipótese tributária "própria" de determinado imposto. Apenas, fez referência a fenômenos econômicos, tendo como pano de fundo tributos preexistentes: dessa forma, conclui que o constituinte não pretendeu, necessariamente, estabelecer rígidos limites para as competências. 
Igualmente em relação às contribuições de melhoria, o ente federado que fez a obra pública e gerou melhoria, é quem terá a competência para instituir o tributo, assim, não há razões para discriminações detalhadas.

As contribuições previstas no art. 149 compreendem: a) as contribuições sociais; b) as contribuições de intervenção no domínio econômico - CIDE; e c) as contribuições de interesse das categorias profissionais ou econômicas. E, ao remeter ao art. 195, também inclui na competência exclusiva da União as contribuições para financiar a seguridade social.

$\mathrm{O}$ art. $149, \S 1^{\circ}$, trouxe, por meio da Emenda 41/03, a possibilidade, em favor dos Estados e dos Municípios, pois a União já a detinha, prevista no art. 40, da criação de uma contribuição que financie o regime de previdência dos seus respectivos servidores públicos.

E, também por meio de Emenda, 39/02, o art. 149-A permitiu a cobrança da chamada contribuição para o custeio do serviço de iluminação pública, em favor dos Municípios.

De forma simplificada, esse é o desenho constitucional das competências tributárias em nosso ordenamento jurídico. No Capítulo IV, iremos analisar, especificamente, as características das espécies tributárias, razão pela qual deixamos de fazê-la neste momento.

No entanto, é importante destacar que competência tributária diz respeito à possibilidade de o ente competente, e somente ele, criar o tributo, o que não se confunde com a arrecadação dele. A ação de arrecadar é chamada de capacidade tributária ativa, e esta pode ser delegada, porque, não há impedimento em o ente constitucionalmente detentor da competência tributária criar o tributo, mas delegar a função de arrecadar a outra entidade, seja pública ou privada.

De tal ideia surge o conceito de parafiscalidade, típico caso das contribuições de interesse das categorias profissionais ou econômicas, art. 149, isto é, quando o ente competente cria um tributo, mas estes recursos irão sustentar entidades que não são propriamente estatais, mas decorrem de atividades que interessam ao Estado, estas entidades seriam parafiscais, e nesse sentido, o Estado, após criar o tributo, imediatamente, repassa as atribuições de fiscalizar, arrecadar e administrar aqueles recursos. ${ }^{202}$

\footnotetext{
${ }^{202}$ DERZI, Misabel. Em nota de atualização na obra: BALEEIRO, Aliomar. Direito tributário brasileiro. $11^{\mathrm{a}}$ ed., Rio de Janeiro: Forense, 2011, p. 81-83.
} 
Essa matéria está expressamente prevista no Código Tributário Nacional, art. $7^{\circ}, \S 3^{\circ}$, o qual permite a delegação das funções de arrecadar ou fiscalizar, ou executar leis, serviços, atos ou decisões administrativas em matéria tributária, até mesmo à pessoa de direito privado. ${ }^{203}$

A Lei 5.172 de 1966 - CTN foi aprovada como lei ordinária, pois assim preconizava a então ordem jurídica vigente, portanto, formalmente é uma lei ordinária. Com o advento da nossa atual Constituição Federal, essa lei foi recepcionada pela nova ordem constitucional.

No entanto, por expressa redação do art. 148, CF/88, algumas matérias tributárias ficaram reservadas à lei complementar, que possui um "quórum" de aprovação qualificado, maioria absoluta. Nesse sentido, o atual CTN, que é a norma geral de direito tributário aplicável à União, Estados e Municípios e dispõe sobre o Sistema Tributário Nacional, somente pode ser modificado por meio de uma lei complementar, porque as matérias tratadas pelo CTN, nesta ordem constitucional, são reservadas à lei complementar. 204205

Ainda em matéria de competência tributária, é fundamental que entendamos as normas constitucionais que, de maneira inversa às tratadas até agora, impedem a instituição de tributos, isto é, a própria Constituição fixa normas que impedem o Estado de criar tributos para determinadas pessoas, situações ou coisas e constituem as chamadas imunidades.

A doutrina pátria ainda não chegou a um consenso do conceito de imunidade, apesar disso, em relação à sua essência, não há maiores discussões. Nesse sentido,

203 Art. $7^{\circ}$ A competência tributária é indelegável, salvo atribuição das funções de arrecadar ou fiscalizar tributos, ou de executar leis, serviços, atos ou decisões administrativas em matéria tributária, conferida por uma pessoa jurídica de direito público a outra, nos termos do $\$ 3^{\circ}$ do artigo 18 da Constituição. (grifo nosso) $\S 1^{\circ} \mathrm{A}$ atribuição compreende as garantias e os privilégios processuais que competem à pessoa jurídica de direito público que a conferir.

$\S 2^{\circ} \mathrm{A}$ atribuição pode ser revogada, a qualquer tempo, por ato unilateral da pessoa jurídica de direito público que a tenha conferido.

$\S 3^{\circ}$ Não constitui delegação de competência o cometimento, a pessoas de direito privado, do encargo ou da função de arrecadar tributos.

O dispositivo constitucional apresentado é referente à Constituição de 1946.

${ }^{204}$ Art. 146. Cabe à lei complementar:

I - dispor sobre conflitos de competência, em matéria tributária, entre a União, os Estados, o Distrito Federal e os Municípios;

II - regular as limitações constitucionais ao poder de tributar;

III - estabelecer normas gerais em matéria de legislação tributária, especialmente sobre: (...)

${ }^{205}$ MACHADO, Hugo de Brito. Curso de direito tributário. 29a ed., São Paulo: Malheiros Editores, 2008, p. 81. 
essencialmente, podemos afirmar que imunidade tributária é uma norma constitucional, que impossibilita a tributação de determinadas pessoas, bens ou situações.

Apesar da falta de consenso em relação ao conceito de imunidade, Paulo de Barros Carvalho, ao analisar uma característica que muitos autores defendem quando cuidam do assunto, a da exclusão ou supressão do poder tributário, faz uma observação que nos parece bastante pertinente, com a qual concordamos e entendemos que deva ser compartilhada.

$\mathrm{O}$ autor entende que as imunidades não excluem nem suprimem competências tributárias. As competências representam o resultado de uma conjunção de normas constitucionais, incluídas as de imunidade. Dessa forma, quando surge a competência para legislar, esta já vem com as demarcações feitas pela própria Constituição. ${ }^{206}$ Compartilhamos dessa ideia, pois entendemos que ela corrobora com a ideia de sistema. Assim, não há que se falar em supressão ou exclusão, pois o constituinte, ao fixar a competência, de forma sistêmica, deixou de outorgar aquela competência específica ao ente. $^{207}$

Durante muito tempo, a doutrina entendia que as imunidades eram referentes, apenas, aos impostos, em razão da redação do art. 150, VI. Todavia, atualmente, não parece mais existirem fortes discussões a respeito do alcance das imunidades em relação a outras espécies tributárias, estas também alcançam as taxas e as contribuições. São vários os exemplos espalhados pela Constituição, art. 5, XXXIV; LXXIII; LXXVI, a) e $b$ ); LXXVII; todos da CF/88, entre outros.

Ainda, é importante lembrar, especialmente em razão do escopo deste estudo, que o art. $6^{\circ}$ do CTN, ao explicitar que a atribuição constitucional de competência tributária compreende a competência legislativa plena, faz referência, tão somente, à competência tributária.

Desse modo, o ente que detém a competência para instituir o imposto sobre a propriedade de veículos automotores, art. 155, III, poderá, em razão da sua competência legislativa plena sobre a matéria, instituí-lo e cobrá-lo da maneira que melhor entender, ressalvadas as limitações contidas na Constituição Federal, nas Constituições dos Estados e nas Leis Orgânicas do Distrito Federal e dos Municípios, e o próprio CTN.

Vejamos, então, a distribuição de competência em matéria ambiental.

${ }^{206}$ CARVALHO, Paulo de Barros. Curso de direito tributário. 19ª ed., São Paulo: Saraiva, 2007, p. 194. 


\subsubsection{Competência ambiental}

Como vimos anteriormente, a distribuição das competências é um pressuposto da forma de Estado Federal. Em consequência, a distribuição de competência ambiental também está estabelecida na própria Constituição.

De plano, importa considerar que, como o conceito de meio ambiente é amplo e abrange elementos naturais, culturais e artificiais, iremos limitar-nos a verificar, quando possível, apenas a distribuição de competência em relação aos elementos ecológicos.

Assim, o art. 225 da CF/88 atribui ao Poder Público em geral a incumbência de defender e preservar o meio ambiente, para as presentes e futuras gerações. De maneira geral, os limites dessas competências estão inseridos nos arts. 21 a 24, CF/88.

Sem dúvida, o art. 23 da CF/88 é o dispositivo mais importante para os fins deste tópico, pois ele traz a competência material comum dos entes públicos, isto é, impõe deveres a todos os entes da Federação.

\footnotetext{
“Art. 23. É competência comum da União, dos Estados, do Distrito Federal e dos Municípios:

(...)

VI - proteger o meio ambiente e combater a poluição em qualquer de suas formas;

VII - preservar as florestas, a fauna e a flora;

$(\ldots)$

XI - registrar, acompanhar e fiscalizar as concessões de direitos de pesquisa e exploração de recursos hídricos e minerais em seus territórios; (grifo nosso)

(...)

Parágrafo único. Leis complementares fixarão normas para a cooperação entre a União e os Estados, o Distrito Federal e os Municípios, tendo em vista o equilíbrio do desenvolvimento e do bem-estar em âmbito nacional."
}

Ainda, em relação à matéria legislativa, o art. 24 determina as matérias que são de competência concorrente.

\footnotetext{
“Art. 24. Compete à União, aos Estados e ao Distrito Federal legislar concorrentemente sobre:

(...)

VI - florestas, caça, pesca, fauna, conservação da natureza, defesa do solo e dos recursos naturais, proteção do meio ambiente e controle da poluição;

(...)

VIII - responsabilidade por dano ao meio ambiente, ao consumidor, a bens e direitos de valor artístico, estético, histórico, turístico e paisagístico;”
}

Portanto, de uma simples análise dos textos constitucionais, percebe-se que todos os entes da Federação são competentes para legislar sobre proteção ambiental. 
Em relação à competência material ou administrativa, ela se consubstancia na execução de tarefas, desenvolvimento de atividades concretas ou exercício efetivo do poder de polícia, a fim de preservar o meio ambiente ecológico. A Constituição atribui tal competência e, nesse caso, estar-se-ia mais para dever, a todos os entes federados.

Cumpre ressaltar que compete privativamente à União legislar sobre águas e energia, art. 22, IV.

Toda essa preocupação na defesa do meio ambiente pode ocasionar, na verdade, inúmeros conflitos de competência, visto que, algumas matérias que integram a competência privativa da União estão, concomitantemente, relacionadas nas competências comum e concorrente dos outros entes da Federação. ${ }^{208}$

Nesse sentido, não existindo legislação federal, com as devidas normas gerais, é bastante provável que surjam conflitos de competência, que só poderão ser solucionados diante do devido caso concreto. No entanto, no que tange à tributação ecológica, tendo o ente público a competência tributária, parece não haver maiores problemas em relação à competência ambiental, uma vez que todos os entes federados estão legitimados, e até obrigados, a defender o meio ambiente e a combater a poluição, em quaisquer das suas formas.

${ }^{208}$ ANTUNES, Paulo de Bessa. Direito ambiental. $5^{\text {a }}$ ed., Rio de Janeiro: Lúmen Juris, 2001, p. 61. 


\section{TRIBUTAÇÃO ECOLÓGICA EM ORDENAMENTOS ESTRANGEIROS}

Se olharmos pelo prisma da teoria econômica, o estudo do uso de instrumentos econômicos com o intuito de solucionar os problemas ambientais vem desenvolvendo-se desde 1920, com a clássica obra de Pigou, The Economics of Welfare, ${ }^{209}$ com a famosa ideia de tributar as externalidades negativas e subsidiar as positivas.

Ocorre que a efetiva implantação dessas ideias somente veio a tornar-se realidade há pouco tempo, por volta de 1970. Desde então, os instrumentos econômicos vêm, paulatinamente, sofrendo evolução.

Philippe Barde afirma que, por volta dos de 1970, os principais instrumentos eram as taxas sobre o usuário ou "user charges"; no período de 1980, eram os "earmarked charges/taxes", pagamentos destinados a algum propósito ambiental, serviços de reciclagem, por exemplo; nos anos de 1990, foi dada ênfase nas taxas com o propósito de incentivo a melhorias ambientais, as "incentive taxes". E, na virada do século, a partir dos anos 2000, a tendência é aprofundar e disseminar as reformas fiscais verdes, "green tax reform". 210

Em estudo recente, a própria OCDE afirmou que a arrecadação de impostos verdes ou ecológicos representou, entre 1994 e 2007, por volta de 7\% dos ingressos tributários totais dos trinta e quatro países que a integram. ${ }^{211}$

Importante destacar que, neste capítulo, faremos uso do método do Direito Comparado, mas não pretendemos discutir as normas ou os sistemas estrangeiros no todo. Pretendemos, apenas, informar as experiências de alguns países, para que, então, no capítulo seguinte, possamos, tomando por base a experiência alienígena exposta, ter mais subsídios para analisar a compatibilidade de um eventual tributo ecológico em nosso sistema jurídico.

\footnotetext{
${ }^{209}$ Op. cit.

${ }^{210}$ BARDE, Philippe. Green tax reforms in OECD countries: an overview. In II Taller Regional de Política Fiscal y Medio Ambiente en America Latina y el Caribe, Santigago de Chile, 27 de enero de 2004. www.oecd.org/env/taxes, acessado em 25.9.2012.

${ }^{211}$ Gabriela Dútrenit Bielous, na apresentação da obra: El sistema tributario, la innovación y el medio ambiente. OCDE, 2010. http://www.keepeek.com/Digital-Asset-Management/oecd/environment/el-sistematributario-la-innovacion-y-el-medio-ambiente 9789264208193-es\#page4 acessado em 3.11.2013.
} 
Dessa forma, desde já se impõe noticiar que muitos dos Estados aqui analisados são Estados unitários, que gera, por si só, diferenças significativas em relação às competências dos seus entes.

Grande parte dos ordenamentos estudados são originários dos países-membros da União Europeia, mas isso não ocorreu de forma aleatória, nem ao acaso. A União Europeia, por meios dos seus Tratados, paulatinamente, introduziu a defesa do meio ambiente como norma comunitária. No entanto, esse processo ocorreu de forma exógena, porquanto muitos países, que já haviam inserido em suas Constituições normas próprias que tutelavam o meio ambiente, estavam sendo afetados, econômica e concorrencialmente, em desfavor de quem não possuía espécie alguma de norma a respeito. ${ }^{212}$

Nesse sentido, o princípio do poluidor - pagador, principal princípio para se criar e cobrar os tributos ecológicos, surge, expressamente, em uma recomendação do Conselho aos Estados-Membros e na comunicação ao Conselho a ela anexa, em 1975. Desde então, tem permanecido em todos os Tratados e enunciados realizados pela União Europeia. ${ }^{213}$ Vejamos alguns exemplos.

\subsection{ESPANHA}

Segundo Luis Herrero, em artigo publicado em 1998, na Espanha prevalecia o uso de instrumentos de comando e controle para a defesa do meio ambiente. Segundo o autor, em razão da tímida política ambiental e das rígidas estruturas do sistema fiscal espanhol, que não permitiriam incorporar com agilidade certas figuras tributárias avançadas, com finalidade ambiental e de caráter extrafiscal. ${ }^{214}$

Posteriormente, em 2002, na conferência promovida pela OCDE, em Berlim, sobre "Reforma Fiscal Ambiental", o Ministro das Finanças Espanhol afirmou, de forma taxativa, que, em razão das possíveis perdas de competitividade das empresas nacionais, não tinha pretensão alguma de criar e cobrar qualquer tipo de novo tributo ecológico, mas iria garantir incentivos fiscais para aqueles que investissem na proteção do meio ambiente. $^{215}$

\footnotetext{
${ }^{212}$ ARAGÃO, Alexandra, op. cit., p. 37.

213 Ibidem, p. 68.

${ }^{214}$ HERRERO, Luis M. Jiménez. Tendencias en el uso de instrumentos económicos y fiscales em la gestión ambiental: reflexiones sobre la Unión Europea y el caso español. In: Fiscalidad Ambiental. Edición a cargo de STERLING, Ana Yábar. Espanha: Cedecs Editorial, 1998, p. 163 - 188, (p.163).

${ }_{215}$ NETO, Jayme Barboza de Freitas; BUENO, Luís Felipe Krieger Moura; COSTA, Luiz Eugênio Porto Servero da. O tributo ambiental à luz do direito comparado. In: Direito Tributário Ambiental. ORLANDO,
} 
No entanto, se é verdade, que o Estado Espanhol não tem demonstrado maiores interesses em instituir e cobrar tributos ecológicos, isso não ocorre com as suas regiões autônomas. Jaime Orte noticia que, ao menos cinco regiões autônomas, possuem tributos com uma finalidade primordialmente ambiental. ${ }^{216}$

Os cinco tributos mencionados são impostos sobre a emissão de gases causadores do efeito estufa. O imposto Gallego sobre a contaminação atmosférica tem como aspecto material a emissão de dióxido de enxofre, ou de qualquer outro composto oxigenado de enxofre, bem como a emissão de dióxido de nitrogênio, ou qualquer outro composto oxigenado de nitrogênio, sempre que provenham de fontes situadas no território da Região da Galícia. ${ }^{217}$

O sujeito passivo, na qualidade de contribuintes, são os proprietários das instalações ou atividades que emitam as substâncias contaminantes. A base de cálculo é a soma das quantidades de cada uma das substâncias contaminantes de um mesmo foco emissor. Esta base de cálculo se determina por médio de estimação direta, fornecida em declaração pelo sujeito passivo e verificada pela Administração, no caso de as instalações terem incorporado sistemas de medidas que meçam a quantidade de substancias emitidas. $^{218}$

Quando as instalações não possuam tais equipamentos, a base será determinada por estimação objetiva, deduzindo-se a quantidade de contaminantes emitidos por meio de indicadores objetivos vinculados à atividade ou ao processo de produção de que se trate, e, de ofício, pela Administração, quando o sujeito passivo impeça ou não forneça as informações necessárias. A obtenção do valor é feita com a multiplicação de um valor predeterminado, pela quantidade de toneladas de substância emitida, com uma escala progressiva em razão do aumento de quantidades emitidas. ${ }^{219}$

A sistemática de todos os outros impostos é igual, com pequenas variações em relação às substâncias, visto que algumas regiões incluem o monóxido de carbono, outras incluem alguns metais pesados. Algumas regiões, ainda, isentam os criadores de aves e suínos. Mas, em essência, a sistemática é igual: mesmo sujeito passivo, mesma base de cálculo e mesma maneira de se encontrar o valor a pagar.

Breno Ladeira Kingma GUDIÑO, Daniel Mariz; TROUW, Ernesto Johannes; GONÇALVES, Fábio Fraga; MUNIZ, Igor; MURAYAMA, Janssen Hiroshi (coords.). Rio de Janeiro: Lumen Juris, 2006, p. 57 - 78 (p.. 76).

${ }^{216}$ ORTE, Jaime Fernández. Op. cit., p. 177.

${ }^{217}$ Ibidem, p. 179.

${ }^{218}$ Ibidem, p. 181.

${ }^{219}$ Ibidem, p. 182. 
As outras regiões autônomas, que possuem impostos sobre a emissão de poluentes, são: a) Castilla-La Mancha; b) Andalucía; c) Murcia; e d) Aragón. ${ }^{220}$

Analisando o imposto Galego, Pedro Herrera Molina faz uma observação bastante peculiar, ao afirmar que esse imposto não leva em consideração as disposições administrativas nacionais, que estipulam limites para as emissões das substâncias tributadas. O tributo incidiria tanto sobre as emissões lícitas, quanto sobre as ilícitas.

Luis Manoel González informa-nos que uma lei das "Islas Baleares", região autônoma da Espanha, criou um tributo sobre a emissão de poluentes, que foi questionada perante o Tribunal Constitucional, essencialmente, em razão de conflito de competência. Supostamente, as bases alvo da tributação já eram objeto de outro tributo, de competência municipal. $^{221}$

Sem ingressar nos inúmeros fundamentos da decisão, aquela Corte chegou à conclusão de que o novo imposto ecológico, na realidade, não tributava a emissão de poluentes, tão somente, utilizava-se daqueles argumentos para, efetivamente, tributar a titularidade de bens imóveis. A forma de quantificação da base de cálculo não representava, em nada, a capacidade de contaminar do sujeito passivo. Portanto, aquele novo imposto invadia competência tributária alheia, razão pela qual fora declarado inconstitucional. ${ }^{222}$

\subsection{DINAMARCA}

Entre 1987 e 1989, a Dinamarca instituiu a sua política sobre resíduos e reciclagem. $\mathrm{O}$ ato normativo sobre o descarte de resíduos introduziu as diretivas da EU sobre resíduos e atribuiu às autoridades locais a responsabilidades pela total gestão dos resíduos. As empresas industriais e comerciais eram obrigadas a fornecer informações para as autoridades locais a respeito da quantidade e da espécie de resíduo produzido. As autoridades, por sua vez, eram obrigadas a encontrar soluções e caminhos para eliminar os resíduos de cada uma delas. Incluía o poder e a obrigação de assegurar que frações

\footnotetext{
${ }^{220}$ Ibidem, p. 177.

221 GONZÁLEZ, Luis Manuel Alonso. Los impuestos ambientais em España: doctrina del Tribunal Constitucional. In: TÔRRES, Heleno Taveira (org.). Direito tributário ambiental. São Paulo, Malheiros Editores, 2005, p. 387 - 411, (p. 406).

${ }^{222}$ Ibidem, p. 409.
} 
reutilizáveis fossem, efetivamente, reclicadas ou reutilizadas por meio dos canais autorizados. $^{223}$

Mais tarde, em 1986, iniciou-se a cobrança da taxa sobre os resíduos, encargo cobrado das plantas de incineração e dos aterros. Estes, invariavelmente, transferiam os custos aos seus clientes. Na prática, a maioria das autoridades locais cobrava um valor fixo das famílias e dos cidadãos, que refletia o custo da coleta e do tratamento dos resíduos domésticos. Nesse sentido, por não se tratar de impostos, os valores cobrados deveriam apenas cobrir os referidos custos e não deixar tipo algum de excedente a longo prazo. ${ }^{224}$

Durante o período dos anos de 1990, a Dinamarca começou a fazer reformas tributárias significativas, todas voltadas à tributação ecológica e consequente conservação do meio ambiente, cuja meta era a redução das emissões de $\mathrm{CO}^{2}$ em $20 \%$, no período de $1988-2005$.

Entre outros objetivos, as reformas almejavam uma redução no custo marginal das alíquotas tributárias em todas as faixas de renda, a eliminação de uma série de lacunas na legislação tributária e uma gradual transferência do imposto sobre a renda e trabalho para um imposto sobre a poluição e recursos naturais escassos. ${ }^{225}$

Dessa forma, em 1992, foi introduzido um tributo sobre a emissão de $\mathrm{CO}^{2}$ dos combustíveis fósseis. Por volta dos anos de 1993/1994, a Dinamarca iniciou uma reforma fiscal na qual substituiu a tributação sobre a renda em favor da tributação ecológica. Essa substituição foi um importante elemento no projeto que visava ao crescimento econômico, associado à resolução de problemas estruturais na economia daquele país e que incluía, ainda, uma reforma no mercado de trabalho. ${ }^{226}$

Em continuidade a essa reforma, o Governo Dinamarquês decidiu implantar numerosas outras iniciativas necessárias para reduzir as emissões de $\mathrm{CO}^{2}$, especialmente em relação a geração/produção de energia. Nesse mesmo período, decidiu impor outro tributo sobre emissão de gases poluentes, dessa vez sobre o SÓ². Então, em 1995, elaborou o que ficou conhecido como "Energy Package", que seria imposto em 1996 e tinha como princípios básicos: a) Significativa melhora do meio ambiente; b) Redução das emissões de $\mathrm{CO}^{2}$, tendo em vista o cumprimento de metas, por meio de tributos, acordos e arranjo de

${ }^{223}$ CHRISTENSEN, Hans. Danish experience with waste charges. In: Papers from Dublin Workshop, Environmental Taxes \& Charges, National Experiences \& Plans, European Foundation, 1996, p. 1- 14, (p. 6) 224 Ibidem, p. 7.

225 BARDE, Philippe. Op. cit., p. 8.

${ }^{226}$ KRISTENSEN, Jens Pagter. Environmental taxes, tax reform and the internal market - some danish experiences and possible community initiatives. In: Papers from Dublin Workshop, Environmental Taxes \& Charges, National Experiences \& Plans, European Foundation, 1996, p. 121 -136 (p. 128). 
subsídios temporários para investimentos em economia de energia; c) Mudança na tributação para fortalecer objetivos ambientais e aumentar a geração de empregos por meio da redução das contribuições sociais; e d) Evitar a deterioração da competitividade, comparada a empresas estrangeiras. ${ }^{227}$

O governo dinamarquês elaborou estudos para analisar qual seria a melhor maneira de evitar que a tributação ecológica causasse desemprego. Ao comparar o efeito "reciclagem" entre o imposto sobre a renda e diante das contribuições sociais, chegou-se à conclusão de que o abatimento dos valores pagos, em razão dos tributos ecológicos sobre as contribuições sociais seria mais efetivo do que se fosse feito com o imposto sobre a renda. ${ }^{228}$

Assim, as receitas obtidas por esses tributos foram totalmente revertidas para a indústria, na forma de redução das contribuições sociais e ajudas em investimentos para eficiência energética. ${ }^{229}$

\subsection{ALEMANHA}

Somente após a inclusão do art. 20 na Constituição Alemã, em 1994, é que a proteção do meio ambiente se tornou um dever expresso, embora, mesmo antes, em função do interesse geral da sociedade, princípio do "bem comum", já existissem inúmeras normas, inclusive tributárias e com caráter extrafiscal, que visavam à proteção do meio ambiente. $^{230}$

Data de 1976 a regulamentação do primeiro tributo extrafiscal com características ecológicas na Alemanha, com aplicação efetiva a partir de 1981. Era uma taxa federal que incidia sobre os efluentes aquáticos e pretendia imputar os custos do tratamento das águas, suportados pelas comunidades, aos causadores do despejo. Incentivou-se, assim, a melhora das técnicas de tratamento, purificação e o desenvolvimento de procedimentos de produção que permitissem reduzir ou eliminar o despejo de efluentes. A quantificação do tributo dependia dos dados refletidos na licença

\footnotetext{
${ }^{227}$ Ibidem, p. 129.

${ }^{228}$ KRISTENSEN, Jens Pagter. Op. cit., p. 132-134.

${ }^{229}$ BARDE, Philippe. Op. cit., p. 8.

${ }^{230}$ NETO, Jayme Barboza de Freitas; op. cit., p. 71.
} 
de despejo de efluentes e não das unidades contaminantes que realmente fluíssem pelas instalações de despejo. ${ }^{231}$

A eficácia ambiental desse tributo é considerada negativa pela maioria dos autores, graças a dois fatores essenciais: a) O tributo só era cobrado daqueles que despejavam os efluentes diretamente na água, embora mais de 90\% dos indivíduos se utilizassem de redes de esgoto, o que fazia com que o tributo não incidisse; e b) $\mathrm{O}$ valor do tributo era muito baixo. ${ }^{232}$ Dessa forma, apesar de esse tributo não ter atingido os seus objetivos de forma satisfatória, percebe-se, nitidamente, o princípio do poluidor-pagador como fonte inspiradora de sua criação.

A Alemanha começou a sua reforma fiscal ecológica em 1999, cujo objetivo central era estimular a eficiência energética. No entanto, poucos anos antes, em 1996, para o então Ministro da Fazenda, introduzir tributos ecológicos poderia implicar o risco de complicar, ainda mais, o sistema tributário alemão e isso levaria à necessidade de regulações adicionais para garantir a neutralidade tributária e lidar com possíveis exceções. $^{233}$

Nahmen atribui alguns critérios essenciais para que se alcance uma formulação efetiva em leis tributárias que fossem ambientalmente orientadas: a) Deveria ser alcançada uma influência na economia nacional que refletisse a política ambiental; b) A posição de potência econômica não deveria ser posta em perigo; c) A função de financiamento do sistema tributário deveria ser preservada; d) O futuro aumento de direitos e obrigações do Estado deveriam ser evitados; e d) $\mathrm{O}$ sistema tributário não deveria ser irracionalmente complicado. ${ }^{234}$

Em 1999, com a Lei da Reforma Tributária Ecológica, houve a reformulação do sistema tributário alemão em prol do meio ambiente, cujo principal objetivo era reduzir a emissão de $\mathrm{CO}^{2}$ em $25 \%$ até o ano de 2005, comparado aos índices de 1990, e aumentar o nível de emprego. Essa reforma tinha dois componentes fundamentais: um novo tributo sobre a eletricidade e o aumento na tributação do óleo mineral. Os dois tributos foram sendo gradualmente elevados de 1999 até $2003 .{ }^{235}$

\footnotetext{
${ }^{231}$ KLUTH, Winfried. Protección del medio ambiente mediante tributos ecológicos en la Republica Federal Alamana. In: Fiscalidad Ambiental. Edición a cargo de STERLING, Ana Yábar. Espanha: Cedecs Editorial, 1998, p. $189-206$ (p. 193).

232 Ibidem, p. 194.

233 NAHMEN, Frank van. Effective formulation of tax laws taking environmental considerations into account. In: In: Papers from Dublin Workshop, Environmental Taxes \& Charges, National Experiences \& Plans, European Foundation, 1996, p. 195 - 199 (p. 195).

234 Ibidem, p. 196.

235 BARDE, Philippe. Op. cit., p. 9
} 
O aumento da carga tributária sobre a energia foi compensado com a redução da carga fiscal sobre o emprego, redução das contribuições sociais tanto para os empregados, quanto para os empregadores. Da mesma forma como ocorreu em outros países, uma série de disposições especiais e isenções foram aplicadas para diferentes fontes de energia, sobretudo para fontes renováveis, plantas de cogeração de energia e para o setor de manufaturas. ${ }^{236}$

No entanto, em relação às indústrias produtivas, de utilização intensiva de energia, e, até mesmo às indústrias de produção agrária e de silvicultura, por temer problemas de competitividade internacional, tendo em vista que a tributação da energia não estava devidamente harmonizada, o legislativo alemão atribuiu uma tributação reduzida para o consumo de energia dessas empresas. Esse tratamento diferenciado gerou bastante polêmica e insatisfação, principalmente no setor de serviços, segundo o qual se tratava de privilégios injustificados, já que não eram todas as indústrias desses setores que competiam internacionalmente, enquanto existiam empresas prestadoras de serviço que competiam no mercado internacional, mas não faziam jus à tributação reduzida. ${ }^{237}$

Desse modo, instalado o conflito, o Tribunal Constitucional Alemão BVerfg foi instado a manifestar-se, visto que, segundo os autores, tal discriminação afetaria os princípios fundamentais da igualdade, da liberdade do exercício profissional e a garantia da propriedade. Em 2004, o BVerfg entendeu que não havia ofensa ao princípio da igualdade, porque, como o legislador não agiu de forma arbitrária, aqueles benefícios estariam em consonância com a sua esfera de liberdade e, ainda, que havia uma diferenciação justificada entre os setores da indústria e dos serviços, visto que, como as indústrias produzem bens, estariam mais expostas à concorrência internacional do que os prestadores de serviço, em geral, mais vinculados ao local de suas sedes, isto é, o próprio mercado interno, em razão da pessoalidade e do imediatismo do serviço. Por fim, em razão de a Constituição alemã não proteger o cidadão contra mudanças nas condições do mercado, bem como porque a carga tributária não se configurou excessiva a ponto de atingir o direito à propriedade, ou seja, confisco. ${ }^{238}$

Winfried Kluth noticia importante notícia referente à competência na Federação alemã, uma vez que lá existem tributos baseados na competência tributária e outros que se apoiam na competência sobre a matéria ambiental. Nesse sentido, ao

\footnotetext{
${ }^{236}$ Ibidem.

${ }^{237}$ NETO, Jayme Barboza de Freitas; op. cit., p. 72.

${ }^{238}$ Ibidem.
} 
diferenciar impostos e tributos especiais de contribuições especiais e taxas, afirma que estas espécies se diferenciam daquelas em razão da impossibilidade de exigi-las sem uma contraprestação. Só é possível exigi-las de forma genérica, como contraprestação de uma atuação administrativa ou do estabelecimento ou manutenção de um serviço público. As taxas e as contribuições especiais estão submetidas a princípios, como o da equivalência e o da cobertura do custo do serviço, que dependem de mera lei ordinária. ${ }^{239}$

Ainda segundo o mesmo autor, o conceito de taxa, na Constituição alemã, é muito flexível. Por isso, o legislador dispõe de ampla margem de atuação para decidir quais fins extraficais podem ser buscados pelas taxas. Ainda se admite, de forma geral, que uma contraprestação de caráter financeiro pode ser utilizada, secundariamente, como instrumento a serviço de fins extrafiscais. Do mesmo modo, pode ser dito das contribuições especiais, embora não se encontrem vinculadas de forma tão estreita ao princípio da contraprestação.

Todavia, conclui o autor, da mesma forma como acontece com os impostos de caráter extrafiscal, deve-se levar em conta que, ao desvincular as taxas e as contribuições especiais do critério da contraprestação, desaparece ou fica comprometida sua justificação constitucional, de modo a serem necessários outros motivos que as fundamentem. ${ }^{240}$

Percebe-se, portanto, uma nítida preocupação com as questões das competências tributária e ambiental, além da adequada escolha da espécie tributária e consequente, justificação dos critérios de legitimação, especialmente quando se trata de extrafiscalidade e tributação ecológica.

\subsection{ITÁLIA}

Em 1999, a Itália começou o seu processo para instituir uma reforma fiscal ecológica. Os principais objetivos de tal reforma eram a remodulação do imposto sobre o consumo do óleo mineral, de acordo com a sua composição de carbono e o seu uso, e a introdução de um tributo sobre o consumo do carvão, do coque de petróleo e do betume natural $^{241}$ usados em plantas de geração de energia à combustão. ${ }^{242}$

\footnotetext{
${ }^{239}$ KLUTH, Winfried. op. cit., p. 202.

${ }^{240}$ Ibidem, p. 203.

${ }^{241} \mathrm{O}$ coque de petróleo e o betume natural são dois subprodutos ou resíduos do processo de destilação de carvão ou de petróleo.

${ }^{242}$ BARDE, Philippe. Op. cit., p. 9.
} 
Porém, desde 1997, existe o imposto sobre a emissão de dióxido de enxofre $\mathrm{SO}^{2}$ e óxido nitroso - NOX, emitidos por grandes instalações e que produzem energia por meio de combustão. O tributo é calculado multiplicando um valor fixo pela quantidade de toneladas emitidas por ano dessas substâncias. No entanto, esse imposto não se aplica às grandes indústrias, que se utilizam dessas substâncias nos seus processos de fabricação. ${ }^{243}$

O tributo sobre o carbono foi introduzida em 1999 e deveria ser revisto depois de cinco anos, a fim de que as emissões italianas fossem reduzidas conforme o estipulado no Protocolo de Kyoto. Mas, já no ano 2000, a reforma foi adiada, sem data para retorno das negociações. ${ }^{244}$

Em 2001, uma importante reforma constitucional revolucionou o campo das competências normativas italianas. Além de dar mais autonomia aos entes locais, trouxe o termo "ambiente" ao texto constitucional e elevou, portanto, à máxima proteção o meio ambiente. Em relação à autonomia dos entes estatais, essa reforma introduziu, do ponto de vista pragmático, um verdadeiro federalismo fiscal, diante do qual os entes estatais possuem uma liberdade muito maior em matéria tributária. ${ }^{245}$

Em 2008, a cidade de Milão criou uma tarifa lá chamada de "ecopass". Para os italianos, trata-se de um verdadeiro tributo, mas que não tem natureza jurídica muito bem definida. Alguns entendem que se trata de uma taxa, outros de um imposto, mas tal figura é, na verdade, muito próxima de um pedágio. A sistemática, de forma muito breve, é a seguinte: A cidade de Milão fechou uma área determinada do seu centro e todo veículo que deseje ingressar naquela área deve pagar uma quantia predeterminada, levando-se em consideração a quantidade de emissões de poluentes do veículo, divididos em cinco categorias, porque ,quanto mais poluente, maior o valor a ser pago. ${ }^{246}$ Todavia, também permite a livre circulação de alguns veículos que não poluem ou tem baixo teor de poluição, tais como ciclomotores, motociclos, veículos movidos a GLP, metano, híbridos ou elétricos. O valor é cobrado por dia, apenas durante os dias de semana, das 7 h30 às 19h30. Fora desses dias e horários, a circulação de qualquer tipo de veículo é liberada.

O interessante dessa espécie de pedágio é que a sua norma instituidora coloca como finalidade precípua fazer com que haja uma diminuição dos índices de emissão

\footnotetext{
${ }^{243}$ FULGHESU, Giuseppina. La fiscalita' ambientale. Quaderno n. 6/2010. Università degli Studi di Foggia. Disponível em: http://www.dseagmeg.unifg.it/pubblicazioni/quaderni.asp acessado em 12.12.2013, p. 48.

244 Ibidem.

${ }^{245}$ SQUILLANTE, Dea, Evoluzione del concetto di tributo ambientale: prospettive interne e comunitarie. Tesi di Dottorato di Ricerca, Facoltà di Giurisprudenza, Università Degli Studi di Napoli "FEDERICO II", 2008, disponível em: http://www.fedoa.unina.it/2761/ acessado em 15.12.2013, p. 95.

${ }^{246}$ Ibidem, p. 117.
} 
veicular e, consequentemente, a diminuição da poluição na cidade não faz referência à diminuição dos congestionamentos.

Os críticos do ecopass milanês afirmam que, na verdade, se trata apenas de mais um tributo, que irá juntar-se à tributação nacional das emissões sobre combustíveis, visto que, na verdade, se estaria tributando a própria propriedade veicular ${ }^{247}$ e, desse modo, seria mais um tributo sobre o mesmo fato representativo de capacidade econômica.

\subsection{FRANÇA}

Já em 1964, a França cobrava um tributo, nos moldes da tributação ecológica. Esse primitivo tributo ecológico era cobrado pela Agência das Águas e incidia sobre a emissão de efluentes e uso da água. Os valores cobrados destinavam-se aos serviços de tratamento e ajuda ao setor privado. ${ }^{248}$

Desde 1989, a França cobra um tributo parafiscal, a Agência do Ar, incorporada à Agência do Ambiente, sobre a exação e financia os sujeitos passivos para desenvolver práticas que melhorem os níveis de proteção atmosférica. Esse tributo incide sobre a emissão dos gases poluentes predeterminados e sua cobrança é feita pela multiplicação de um valor fixo pela quantidade de toneladas/ano emitidas. ${ }^{249}$

Em 1999, teve início uma reestruturação no sistema tributário francês. Os objetivos principais dessa reestruturação eram a melhoria da eficiência e a simplificação de uma série de tarifas sobre emissões já existentes.

No início do ano 2000, existiam tarifas sobre a poluição atmosférica, dejetos domésticos, tratamento e estocagem de resíduos industriais especiais, óleos e lubrificantes e poluição sonora, cobrados pela Agence de l'Environment et de la Maîtrise de l'Energie ADEME. Com a reforma todas essas cobranças passaram a ter uma designação única, Taxe générale sus lês activités polluantes - TGAP, a cargo do Ministério das Finanças e não mais do Ministério do Meio Ambiente, embora a receita com a TGAP retorne para o ADEME, por meio de uma alocação orçamentária anual. ${ }^{250}$

A França também introduziu tributos sobre detergentes, pesticidas e granulados, que são uma espécie de pesticida. Ainda em 1999, foi iniciada uma progressiva

\footnotetext{
${ }^{247}$ Ibidem, p. 120.

248 ROSEMBUJ, Tulio. Los tributes y la protección del medio ambiente. Madrid, Marcial Pons Ediciones Juridicas, S.A., 1995, p. 97.

${ }^{249}$ Ibidem, p. 98.

${ }^{250}$ BARDE, Philippe. Op. cit., p. 8.
} 
redução no diferencial da carga tributária entre a gasolina e o óleo diesel combustível, para automóveis, interrompida em razão de pressões políticas. ${ }^{251}$

Houve a tentativa de estender-se a TGAP para o consumo de combustíveis fósseis e eletricidade, com o intuito de atingir as metas de redução de emissões firmadas em tratados internacionais, rejeitada pela Corte Constitucional Francesa, ainda no ano 2000, sob o argumento de que seria um tratamento desigual sobre os específicos segmentos da indústria.

\subsection{SUÉCIA}

A Suécia é tida como o primeiro país a implantar, efetivamente, uma grande reforma fiscal ecológica, cujas transformações fiscais ocorreram durante o período de 1990/1991. A grande característica dessa reforma foi a diminuição do imposto sobre a renda, compensando-se com um aumento no imposto sobre o comércio e a criação de vários tributos ecológicos, especialmente sobre a emissão de carbono e enxofre. ${ }^{252}$

Em 1991, quando o imposto sobre o $\mathrm{CO}^{2}$ era no valor de SEK 250 por tonelada/ano, os impostos sobre a energia industrial foram reduzidos pela metade, no entanto, ainda assim, resultaram na maior tributação de energia. Em 1993, o setor de manufaturados garantiu o corte de $75 \%$ na emissão de $\mathrm{CO}^{2}$ e foi completamente isentado do imposto geral sobre a energia. Em 1997, o valor da isenção diminui para apenas 50\%. 253

Ainda, em 1991, entrou em vigor o imposto sobre as emissões de óxido de nitrogênio - NOX para as grandes centrais elétricas.

O imposto sobre enxofre é cobrado sobre carvão, petróleo, coque petróleo e outros produtos gasosos. Ainda existe uma diferenciação nas alíquotas a serem aplicadas em três diferentes categorias de óleo diesel, conforme a sua composição de enxofre, porque quanto maior a concentração de enxofre, maior será a alíquota. ${ }^{254}$

Dessa forma, a Suécia, em uma reforma só, criou um imposto sobre o $\mathrm{CO}^{2}$, que grava os diferentes tipos de combustíveis conforme o seu conteúdo de carbono, um imposto sobre a quantidade de toneladas emitidas de $\mathrm{SO}^{2}$. As emissões produzidas pelas grandes indústrias são diretamente tributadas e os diferentes combustíveis são tributados

\footnotetext{
${ }^{251}$ Ibidem.

${ }^{252}$ Barde, Philippe. Op. cit., p. 7.

253 Ibidem.

254 Ibidem.
} 
conforme o respectivo conteúdo de enxofre. Há, também, um imposto por tonelada emitida de NOX, cobrado diretamente das 250 instalações de combustão mais importantes, as centrais elétricas, cujo produto arrecadado é reembolsado, na proporção da quantidade de energia produzida, de modo a estimular a eficiência energética. ${ }^{255}$

Todos esses impostos, além da nítida proteção do meio ambiente de forma geral, tiveram algumas causas próprias naquele país. Como se trata de um país geograficamente pequeno, com terras, rios e lagos limitados, todos esses componentes químicos favorecem, em menor ou maior grau, as chuvas ácidas. Ocorre que o solo sueco, por natureza, é extremamente sensível ao acúmulo de ácidos e a Suécia ainda é um dos países mais acidificados do mundo, o que resulta em graves problemas.

Em relação especificamente ao nitrogênio, esse produto é o maior agente causador da eutrofização, uma espécie de poluição por excesso de nutrientes em águas, que acaba por diminuir a concentração de oxigênio nelas existente. Em geral, normalmente decorre dos fertilizantes, o que gera graves consequências para o sensível mar Báltico. ${ }^{256}$

Percebe-se que, apesar das preocupações gerais, a Suécia já possuía problemas ecológicos específicos, que precisavam ser solucionados. Assim, ao fazer as suas mudanças, aproveitou para atacar as raízes desses problemas, emissão de $\mathrm{SO}^{2}, \mathrm{CO}^{2} \mathrm{e}$ NOX, responsáveis por ocasionar também outros efeitos danosos.

\subsection{ESTADOS UNIDOS DA AMÉRICA}

Em 1986, os Estados Unidos da América - EUA, por meio da lei de revisão do "Comprehensive Environmental Response, Compensation and Liability Act, 1980 CERCLA", instituíram o famoso fundo de reparação de danos ao meio ambiente, conhecido como superfund, superfundo.

Esse Fundo é constituído por diversas receitas, principalmente pelas oriundas dos impostos sobre o petróleo e matérias-primas, cujos recursos são destinados à promoção da limpeza de locais degradados pela poluição de resíduos químicos de produtos perigosos e derivados. ${ }^{257}$

\footnotetext{
${ }^{255}$ ROSEMBUJ, Tulio. op., cit., p. 99.

${ }^{256} \mathrm{KAHN}$, Jon. Economics instruments to abate acidification in Sweden. In: Papers from Dublin Workshop, Environmental Taxes \& Charges, National Experiences \& Plans, European Foundation, 1996, p. 113 - 120. (p. 113)

${ }^{257}$ OLIVEIRA, José Marcos Domingues. Direito tributário e meio ambiente. $3^{\mathrm{a}}$ ed., Rio de Janeiro: Forense, 2007, p. 31.
} 
Nos EUA, diversos estados utilizam a incidência de tributos sobre o lixo doméstico, com o intuito de estimular a reciclagem. No plano federal, importante e bem sucedida experiência foi a que instituiu um tributo sobre produtos lesivos à camada de ozônio, conhecido como OCD - Ozone Dpleting Chemical taxation, que tem como núcleo da hipótese de incidência a potencialidade de destruição da camada de ozônio dos produtos. Os sujeitos passivos não são apenas os produtores, mas também os importadores. Dessa forma, os EUA aplicam ajustes na tributação alfandegária em relação a esses produtos, para não prejudicar a competitividade internacional de suas empresas. ${ }^{258}$

O ajuste alfandegário funciona basicamente da seguinte maneira: a) Os exportadores são reembolsados do valor do tributo pago, uma vez que esse tributo não existe na maior parte dos países; b) Os produtos importados são tributados conforme possuam componentes lesivos à camada de ozônio, ou o seu processo produtivo possa ter causado esse efeito. ${ }^{259}$ Dessa forma, o Estado americano consegue equiparar o preço dos produtos nacionais que, em tese, sairiam mais caros, ao dos produtos estrangeiros, que, em tese, chegariam mais baratos.

Os EUA ainda impõem um adicional ao imposto de renda do indivíduo que provocar danos ao meio ambiente, assim como permitem a dedução da base de cálculo do mesmo imposto para aqueles que fizerem doações de áreas com finalidades de preservação ambiental. ${ }^{260}$

Todavia, o Estado americano é um dos poucos que não quis comprometer-se ao cumprimento das metas do Protocolo de Kyoto - 1997, visto que isso iria afetar, de maneira drástica, a sua economia. Sendo assim, os EUA não possuem uma verdadeira política de tributação ecológica, tampouco têm demonstrado sinais de que pretende implementar algum tipo de reforma nesse sentido.

\subsection{BÉLGICA}

Em 1993, o governo belga introduziu uma lei federal que integrava questões fiscais e ambientais. Mas, antes de falarmos, concretamente, sobre a tributação ecológica na Bélgica, é importante que se façam alguns esclarecimentos acerca do sistema federal daquele país. A Federação Belga é composta por três comunidades, que lidam,

\footnotetext{
${ }^{258}$ NETO, Jayme Barboza de Freitas; op. cit., p. 77.

${ }^{259}$ Ibidem.

${ }^{260}$ NUNES, Cleucio Santos. Direito tributário e meio ambiente. São Paulo: Dialética, 2005, p. 186.
} 
prioritariamente, com questões culturais e educacionais, e três regiões, que têm as principais competências relacionadas ao território, tais como economia, habitação, uso do solo, infraestrutura. ${ }^{261}$

Dessa forma, as questões relacionadas à matéria ambiental, normalmente, são tratadas pelas três regiões. O governo nacional tem poderes restritos, essencialmente sobre padrões dos produtos, resíduos nucleares e para negociação e implantação dos acordos internacionais celebrados pelo Estado. Nesse sentido, é importante destacar que não há hierarquia entre os sistemas legais existentes na Bélgica, além de que o governo nacional não pode impor sua vontade, no que diz respeito à matéria ambiental, sobre os governos regionais. No entanto, ao contrário do que ocorre com a competência ambiental, a competência para tratar tributos sobre o comércio é do ente nacional, de modo que, a decisão de integrar questões ambientais com o sistema tributário compete ao Governo Federal, apesar de as regiões terem total interesse na matéria, porque a lei disciplina que as receitas oriundas desses tributos serão transferidas para o orçamento das regiões. ${ }^{262}$

Partindo da premissa de que a mudança do comportamento do consumidor traz um retorno positivo para o próprio sistema econômico, igualmente, o comportamento dos produtores também mudaria, porque eles têm o claro interesse em oferecer mais bens atrativos ao consumidor, a fim de proteger e expandir as suas respectivas fatias do mercado. Assim, com base nessa ideia, a chamada tributação ecológica belga incide sobre produtos e não sobre emissões. O principal objetivo dessa lei é induzir o comportamento do cidadão belga a consumir de maneira ecologicamente mais adequada. ${ }^{263}$

Os principais produtos tributados são os recipientes descartáveis de bebidas, produtos descartáveis, como lâminas para barbear, baterias, pesticidas e até mesmo o papel, com o intuito de incrementar o uso do papel reciclável. ${ }^{264}$

Como o tributo belga é um tributo monofásico sobre o consumo e a Bélgica já tinha um imposto sobre o consumo plurifásico, o VAT, houve alguns problemas na implantação desse tributo.

Os principais problemas enfrentados pelos belgas foram: a) Evitar a ligação entre tributos indiretos que possam obstaculizar a distribuição e, mais especificamente, as exortações; b) Evitar a discriminação entre os produtores belgas e estrangeiros; c) Evitar a

\footnotetext{
${ }^{261}$ CLERQ, Marc De. The implementation of green taxes: the Belgian experience. In: Papers from Dublin Workshop, Environmental Taxes \& Charges, National Experiences \& Plans, European Foundation, 1996, p. $45-66$ (p. 45).

${ }^{262}$ Ibidem. p. 46.

263 Ibidem, p. 48

264 Ibidem, p. 54.
} 
monitoração de cadeias distributivas muito complexas; e d) Evitar cair na armadilha de eles mesmos criarem brechas, ao permitirem o uso de exceções e isenções em relação aos tributos indiretos. ${ }^{265}$

A solução encontrada, apesar de significar um custo maior para a administração fazendária e um risco maior de fraudes, em razão da separação dos momentos de cobrança e fiscalização em relação ao VAT, foi postergar o momento da incidência, para somente ocorrer no final da cadeia produtiva. Dessa maneira, em 1996, o legislador belga alterou a legislação. ${ }^{266}$

\subsection{HOLANDA}

Pode-se dizer que a tributação ambiental na Holanda começou em 1988, com o tributo geral sobre combustíveis, cujo objetivo central foi financiar as despesas ambientais do governo. Esse tributo foi à reunião de mais de quinze outros tributos com finalidade específica, isto é, tributos cujas receitas eram vinculadas a finalidades específicas, tais como o da poluição atmosférica, da poluição sonora automobilística, poluição sonora industrial e resíduos químicos. O argumento para a reunião de todos esses tributos foi de que era necessário racionalizar tais cobranças, a fim de melhorar a arrecadação e dar mais eficiência ao sistema. ${ }^{267}$

A Holanda possui um verdadeiro sistema Fiscal ecológico porque os tributos ecológicos nesse país têm o firme propósito de gerar e aumentar os recursos do orçamento geral. Em 1995, somando a arrecadação dos tributos sobre a eliminação de resíduos (criado em 1995), águas subterrâneas em geral (criado em 1995) e sobre os combustíveis (criado em 1992), eles alcançaram 1,3\% da arrecadação total. ${ }^{268}$

Em 1996, eram cinco tributos ecológicos, os três acima mencionados, mais um tributo sobre o urânio (criado em 1995, mas cobrado a partir de 1997), e um tributo

\footnotetext{
${ }^{265}$ PITTEVILS, Ivan. Ecotaxes on products in Belgium: the need for a proper point of imposition. In: Papers from Dublin Workshop, Environmental Taxes \& Charges, National Experiences \& Plans, European Foundation, 1996, p. $201-209$, p. 209.

${ }^{266}$ Ibidem, p. 209.

${ }^{267}$ HENDERSON, Anthonie. Waste charge and taxes in the netherlands. In: Papers form Dublin Workshop, Environmental Taxes \& Charges, National Experiences \& Plans, European Foundation, 1996, p. 97 - 111, p. 104.

${ }^{268}$ LEDER, Arie. Taxes with an environmental base and the Duch Green Commission. In: Papers from Dublin Workshop, Environmental Taxes \& Charges, National Experiences \& Plans, European Foundation, 1996, p. 159 - 170. p. 159.
} 
regulatório sobre o pequeno consumidor de energia (criado em 1996): a soma de todos esses tributos representou $1,8 \%$ da arrecadação total.

Ariel Leder, discorrendo sobre os tributos ecológicos holandeses, afirma que como eles são, precipuamente, fiscais, para manter o sistema tributário o mais simples possível, o número de isenções deve ser mantido no mínimo. No entanto, em relação ao tributo sobre o pequeno consumidor de energia, afirma que é regulatório em razão de o objetivo central desse tributo não ser incrementar os cofres públicos, já que as suas receitas são recicladas, devolvidas de forma a subsidiar outros tributos, como o imposto de renda e as contribuições sociais. ${ }^{269}$

O atual imposto sobre combustíveis é a evolução daquele primeiro tributo geral sobre combustíveis, de 1988. Em 1992, houve uma mudança na legislação desse tributo e as suas receitas, que eram vinculadas a alguns gastos governamentais relacionados com o meio ambienta, deixaram de ser. O combustível foi escolhido como base de cálculo porque se percebeu que ele forneceria uma ligação com o princípio do poluidor - pagador, além de um grande índice de poluição ser derivado do uso do combustível, tais como atmosférica, sonora e até mesmo transtornos, em razão do trânsito. ${ }^{270}$

Os valores variam conforme a quantidade de carbono e energia que cada combustível contém. Para o combustível com grande quantidade de carbono e energia, intensa energia industrial, serão analisados os gases residuais (alto-forno, forno de coque, carvão, gases de refinaria e gases químicos), e o uso de gás natural terá um valor mitigado.

O imposto sobre óleos minerais é cobrado com o imposto sobre o consumo desses óleos. O imposto sobre o gás e o carvão é devido pelas pessoas que os extraem, produzem ou importam esses combustíveis e, subsequentemente, os usem como combustíveis ou os transfiram para outros que também os usem como combustíveis. ${ }^{271}$

O imposto sobre a captação de águas subterrâneas tem como argumento básico de justificação a própria escassez de água subterrânea doce, boa e limpa, especialmente onde a produção de água potável e o uso de águas subterrâneas por alguns setores industriais estejam envolvidos. Os sujeitos passivos captam as águas e a incidência

\footnotetext{
${ }^{269}$ Ibidem.

${ }^{270}$ Ibidem, 160.

${ }^{271}$ Ibidem, p. 161.
} 
ocorre quando a captação é feita. O valor cobrado é relativo à quantidade de metros cúbicos captados e um valor fixo predeterminado ${ }^{272}$.

O imposto sobre o urânio serve para tributar, de forma indireta, a produção de energia elétrica oriunda de plantas nucleares, da mesma forma que é tributada a energia elétrica produzida por fontes mais tradicionais. O valor cobrado é um valor fixo multiplicado por grama de urânio utilizado. ${ }^{273}$

$\mathrm{O}$ imposto sobre os pequenos consumidores de energia, tributo eminentemente regulatório, possui dois objetivos principais: o primeiro consiste em dar incentivos financeiros para conservação de energia e diminuição de emissões de $\mathrm{CO}^{2}$, além de dar continuidade à política de incrementação do uso de instrumentos de mercado e expressar o custo social das atividades poluidoras de forma mais efetiva; o segundo consiste em dar continuidade à política de transferência das bases tributárias sobre o trabalho para o uso do meio ambiente. ${ }^{274}$

\subsection{ALGUMAS CONSIDERAÇÕES}

Como se pode perceber, grande parte dos países analisados é do continente europeu e uma das principais razões para que isso ocorra é o próprio Tratado da União Europeia, que, expressamente, prevê a defesa do meio ambiente por meio da implantação do princípio do poluidor-pagador.

\footnotetext{
"Artigo 191. o

(ex-artigo 174. o TCE)

2. A política da União no domínio do ambiente terá por objetivo atingir um nível de proteção elevado, tendo em conta a diversidade das situações existentes nas diferentes regiões da União. Basear-se-á nos princípios da precaução e da ação preventiva, da correção, prioritariamente na fonte, dos danos causados ao ambiente e do poluidor-pagador." (grifo nosso)
}

Nesse sentido, por força de Norma Comunitária, os integrantes da União Europeia têm o dever de defender o meio ambiente e basear suas atuações no princípio do poluidor-pagador, entre outros.

Nota-se, também, que grande parte dos países analisados possui alguma espécie de tributo ambiental sobre a produção de energia e sobre o uso de combustíveis fósseis. O principal objetivo desses tributos é a diminuição dos gases que provocam o

\footnotetext{
272 Ibidem, p. 162.

${ }^{273}$ Ibidem, p. 164.

${ }^{274}$ Ibidem.
} 
efeito estufa. Contudo, essa decisão foi tomada em razão da pressão internacional pela melhoria do meio ambiente na Terra e pelos estudos que demonstravam como o Planeta estava aquecendo de forma mais rápida do que se imaginava nos primeiros estudos sobre o tema.

Dessa forma, em 1997, foi assinado o Protocolo de Kyoto, que constitui um tratado complementar à Convenção-Quadro das Nações Unidas sobre Mudança do Clima, Rio de Janeiro - 1992. Esse Protocolo estabelece metas de redução nas emissões dos gases que causam o efeito estufa, o mínimo de $5 \%$ em relação aos níveis de emissão do ano de 1990, sobretudo aos países já desenvolvidos. Dentre os principais emissores de gases de efeito estufa, somente os EUA não ratificaram o Protocolo, sob o argumento de que tal compromisso afetaria, de maneira substancial, a sua economia interna.

Em tal contexto, os principais gases que causam o efeito estufa decorrem da queima de combustíveis fósseis, utilizados tanto para geração de enérgica elétrica quanto para locomoção de automóveis. Ocorre que, na Europa, a principal fonte de geração de energia elétrica ainda é a queima de combustíveis fósseis, notadamente derivados de petróleo, ${ }^{275}$ seguida das usinas nucleares.

Diferentemente, em nosso Estado, por facilidades geográficas naturais, temos como principal fonte de geração de energia as hidroelétricas, que, por sua própria natureza, são consideradas fontes limpas, visto que não geram gases que provocam o efeito estufa.

Nesse sentido, os Estados da União Europeia têm uma razão muito forte, do ponto de vista prático, para tributar a geração de energia, uma vez que essa atividade é considerada uma das principais fontes de emissão dos gases causadores do efeito estufa.

A tributação ambiental em alguns países tem-se demonstrado um eficaz mecanismo de mudança de comportamentos ecologicamente degradantes ou não apropriados, embora não exista apenas uma espécie ou um tributo com características iguais adotados por todos os países analisados.

Todavia, podemos afirmar que existem algumas características semelhantes em alguns desses tributos analisados e isso se explica até em razão de a maioria dos países analisados fazer parte da OCDE. Esse organismo internacional já elaborou, e continua a elaborar, inúmeros estudos a respeito do tema da tributação ambiental e, em alguns desses

${ }^{275}$ COSTA, Carla Guapo. A matriz energética da União Europeia e o caso particular dos biocombustíveis: diagnóstico e perspectivas. In: Oficinas do CETEM - Centro de tecnologia mineral. Rio de Janeiro, 2010. Disponível em: http://www.cetem.gov.br/agrominerais/documentos/oficina5/Apresentacao04.pdf acessado em 10.12.2013. 
estudos, é demonstrada uma forma de tributar a emissão de substâncias poluidoras. ${ }^{276}$ Os países analisados seguem, de maneira geral, esse método proposto pela OCDE.

Note-se que, com base na experiência comparada, existem várias possibilidades de se tentar imputar um valor à poluição, seja tributando-a diretamente, seja tributando o consumo de bens ecologicamente degradantes.

Com base nas lições de Misabel Derzi, o uso do tipo no direito comporta três significados distintos: um sentido metodológico; um sentido oposto ao de conceito rígido e delimitado; e um sentido próprio no direito tributário, que se refere a limites, máximos ou mínimos, ou parâmetros criados pela Administração, sob o argumento, supostamente, de simplificação da aplicação da lei. ${ }^{277}$

Para a autora, o tipo comporta flexibilidade estrutural e remete à abertura. Existem notas, características, não necessariamente constantes em todos os objetos que abrange, mas que permitirão distingui-los. As características são renunciáveis e graduáveis e, quanto mais irrenunciável e necessária se torna uma característica, mais perto se estará do conceito fechado. ${ }^{278}$

Dessa forma, valendo-nos das lições da autora mineira, dos tributos encontrados e expostos oriundos da experiência estrangeira e das propostas da OCDE, podemos dizer que um típico tributo ecológico tenta alcançar a própria poluição. Dito de outra maneira, tributo ecológico é o tributo que tem na sua base de cálculo alguma espécie de ação que gera poluição.

E, tipicamente, os tributos que encontramos com esse perfil foram os incidentes sobre a emissão de algum gás causador do efeito estufa, na produção de energia elétrica ou decorrente da utilização de combustível fóssil em automóveis.

Tais tributos, ainda, que têm na sua base de cálculo uma ação de poluir, tipicamente têm suas receitas vinculadas à desoneração dos encargos trabalhistas, isto é, os valores pagos em função da tributação sobre a poluição retornam como subsídios para compensar as possíveis perdas de competitividade das empresas.

Com base nessas premissas, iremos analisar, no capítulo seguinte, quais as características de um tributo ecológico no Sistema Tributário Nacional.

\footnotetext{
${ }^{276}$ EUROPEAN COMMISSION. Manual: Statistics on Environmental Taxes. Version 3.0., 28.7.1996.

${ }^{277}$ DERZI, Misabel de Abreu Machado. Direito tributário, direito penal e tipo. $2^{\mathrm{a}}$ ed., São Paulo: Revista dos Tribunais, 2007, p. 68.

${ }^{278}$ Ibidem. p. 91-92.
} 


\section{CARACTERÍSTICAS DE UM TRIBUTO ECOLÓGICO}

Como visto no capítulo anterior, quando se fala em tributo ecológico é preciso entender que não há um conceito definitivo fechado a esse respeito. Da mesma forma, notamos que inúmeros tributos podem ser utilizados para se tentar tributar a poluição. Chegamos a essa conclusão pela análise da experiência estrangeira.

Porém no nosso sistema não existe tributo ecológico algum. Com base na ideia de tibutar a propria poluição, neste capítulo iremos analisar a estrutura de um possível tributo, ou melhor, iremos analisar a estrutura de um típico tributo ecológico encontrado nos ordenamentos alienígenas.

Contudo, isso não significa que estejamos simplesmente importando aquele tributo estrangeiro para o nosso sistema, ao contrário, estamos testando a compatibilidade do típico tributo ecológico estrangeiro com o nosso sistema, a fim de verificarmos se é possível a criação de um tributo nesses termos em nosso ordenamento jurídico.

Nesse sentido, iremos começar a nossa análise pelas espécies tributárias, para só depois verificarmos os seus elementos constitutivos.

\subsection{ESPÉCIES TRIBUTÁRIAS ADEQUADAS À TRIBUTAÇÃO ECOLÓGICA}

Para que possamos defender qual a espécie ou as espécies tributárias mais adequadas à tributação ecológica, é fundamental que tenhamos, no mínimo, uma noção das características essenciais de cada espécie tributária existente em nosso ordenamento jurídico. Dessa forma, sem ingressar na discussão doutrinária a respeito do número de espécies tributárias existentes, assumimos a classificação quinquipartida, que admite cinco espécies tributárias: (i) impostos, (ii) taxas, (iii) contribuição de melhoria, (iv) contribuições (estas com as mais variadas denominações) e (v) empréstimos compulsórios. Iremos dar ênfase aos impostos, às taxas e às contribuições e, posteriormente, trataremos de outras espécies.

No entanto, antes de ingressarmos, efetivamente, no campo das espécies tributárias, é importante destacarmos a observação feita por Schoueri, no sentido de que a 
chave para a compreensão sistemática da repartição de competências tributárias no ordenamento jurídico nacional está na diferenciação dos tributos conforme a sua vinculação ou não. ${ }^{279}$

O autor afirma que entender a questão da vinculação é importante porque, quando os tributos se justificam pelo sinalagma, a competência tributária confunde-se com a própria atribuição constitucional de competências materiais. ${ }^{280}$ Dessa forma, quando se trata de tributo vinculado, o ente que tiver a competência material para exercer aquela atividade estatal também terá a competência tributária. Quando se trata de tributo não vinculado, justificado pela capacidade contributiva, o constituinte resolveu a questão atribuindo a cada ente uma parcela exclusiva de competência.

Essa questão é de vital importância quando se trata de tributo ecológico, porque, como foi visto, a imposição de um tributo ecológico pressupõe as competências tributária e ambiental, conjuntamente.

Apenas com o intuito de esclarecimento, sem ingressar em maiores discussões doutrinárias a respeito da diferenciação dos termos "hipótese de incidência" e "fato gerador" e valendo-nos das lições de Schoueri, adotaremos, quando possível, o termo "hipótese tributária" para a situação abstrata (o "fato gerador" abstrato), e "fato jurídico tributário" para os casos de concretização (o "fato gerador" concreto). ${ }^{281}$

\subsubsection{Impostos}

Ruy Barbosa Nogueira ${ }^{282}$ afirma que imposto é o tributo, cuja obrigação tem como fato gerador, nuclear, uma situação independente de qualquer atividade estatal específica relativa ao contribuinte, e remete-se ao conceito definido pelo art. 16 do Código Tributário Nacional - CTN.

"CTN - Art. 16. Imposto é o tributo cuja obrigação tem por fato gerador uma situação independente de qualquer atividade estatal específica, relativa ao contribuinte."

\footnotetext{
${ }^{279}$ SCHOUERI, Luís Eduardo. Direito tributário. op. cit., p. 239.

${ }^{280}$ Ibidem,

${ }^{281}$ Ibidem, p. 434.

${ }^{282}$ NOGUEIRA, Ruy Barbosa. Curso de direito tributário. 15ª ed., São Paulo: Saraiva, 1999, p. 157.
} 
Para o autor, as duas características fundamentais do imposto, cobrança geral e a não vinculação a qualquer atividade estatal, estão nitidamente presentes nesse dispositivo legal. Afirma, ainda, que essa espécie, que é a viga mestra da arrecadação tributária, baseia-se apenas em uma medida geral de capacidade econômica ou contributiva e na competência tributária. ${ }^{283}$

Para Luciano Amaro, mesmo que o fato gerador do imposto não seja um ato do Estado, esse ato deve configurar uma situação com a qual o contribuinte se vincule. $\mathrm{O}$ legislador tem o dever de escolher determinadas situações materiais que evidenciem capacidade contributiva e, dessa forma, as pessoas que se vinculam a essas situações irão assumir o dever jurídico de pagar o imposto em favor do Estado. ${ }^{284}$

Ruy Barbosa Nogueira assevera que o imposto não corresponde ao preço pago por vantagens que o Estado forneceu ao contribuinte, ao contrário, diz respeito à obtenção de riqueza para os cofres públicos. ${ }^{285}$

Schoueri, na mesma linha de pensamento, afirma que os impostos se justificam a partir das necessidades financeiras do Estado e servem para cobrir gastos que não se imputam a um ou outro contribuinte, de maneira individualizada. ${ }^{286}$

É precisamente dessa premissa que surge a ideia de capacidade contributiva. Se todos têm de arcar, contribuir para as despesas gerais do Estado, então deve haver algum critério para quantificar qual será a parcela de contribuição de cada indivíduo. Trata-se, portanto, de um critério de justiça.

Por essa razão, o art. $145, \S 1 .^{\circ}$ da $\mathrm{C} / 88$, estabelece que os impostos, sempre que possível, terão caráter pessoal e serão graduados conforme a capacidade econômica do contribuinte e desse modo deve levar em conta circunstância que diga respeito ao próprio contribuinte. $^{287}$

No entanto, capacidade contributiva não deve ser entendida de forma tão estrita, ao menos num primeiro momento, já que, quando o legislador for criar o imposto, deve procurar uma circunstância que possa servir para distinguir aqueles quem pode de quem não pode suportar os gastos públicos. ${ }^{288}$

\footnotetext{
${ }^{283}$ Ibidem.

${ }^{284}$ AMARO, Luciano. Direito tributário brasileiro. 16 ${ }^{\mathrm{a}}$ ed., São Paulo: Saraiva, 2010, p. 52.

${ }^{285}$ Op. cit., p. 158.

${ }^{286}$ SCHOUERI, Luís Eduardo. Direito tributário, op. cit., p. 191.

${ }^{287}$ COSTA, Regina Helena. Curso de direito tributário: Constituição e Código Tributário Nacional. $2^{\mathrm{a}}$ ed., São Paulo: Saraiva, 2012, p. 128.

${ }^{288}$ SCHOUERI, Luís Eduardo. Direito tributário. op. cit., p. 196.
} 
Outra característica fundamental em relação aos impostos é a que está posta no art. 167, IV, norma que diz respeito à não afetação.

\begin{abstract}
"Art. 167. São vedados:
$\mathrm{V}$ - a vinculação de receita de impostos a órgão, fundo ou despesa, ressalvadas a repartição do produto da arrecadação dos impostos a que se referem os arts. 158 e 159, a destinação de recursos para as ações e serviços públicos de saúde, para manutenção e desenvolvimento do ensino e para realização de atividades da administração tributária, como determinado, respectivamente, pelos arts. 198, § $2^{\circ}, 212$ e 37, XXII, e a prestação de garantias às operações de crédito por antecipação de receita, previstas no art. $165, \S 8^{\circ}$, bem como o disposto no $\S 4^{\circ}$ deste artigo."
\end{abstract}

Portanto, além de os impostos serem prestações não sinalagmáticas, também são tributos cuja receita não é afetada a nenhum órgão, fundo ou despesa, em regra, uma vez que a própria Constituição pode trazer exceções à norma, como o faz.

Ainda, como já vimos, quando tratamos da competência tributária, o imposto é a única espécie tributária que já vem taxativamente prevista na Constituição. Isso significa dizer que apenas os impostos previstos na Constituição poderão ser objeto de lei instituidora e posterior cobrança.

\title{
5.2 TAXAS
}

Diferentemente de como se dá em relação aos impostos, o direito positivo brasileiro não conceituou a espécie tributária denominada taxa.

Apesar de tal omissão, é perfeitamente possível formular uma definição para tal espécie tributária, com base no texto constitucional. O dispositivo que fornece os elementos necessários para tanto é o inciso II do art. 145 da Constituição Federal, assim redigido:

\footnotetext{
“Art. 145. A União, os Estados, o Distrito Federal e os Municípios poderão instituir os seguintes tributos:

(...)

II - taxas, em razão do exercício do poder de polícia ou pela utilização, efetiva ou potencial, de serviços públicos específicos e divisíveis, prestados ao contribuinte ou postos à sua disposição;

$(\ldots) "$
}

Com efeito, podemos identificar que a taxa pode ser definida como o tributo, cujo fato gerador é o exercício regular do poder de polícia ou a utilização, efetiva ou 
potencial, de um serviço público específico e divisível. Assim sendo, de plano, conseguimos identificar a presença do Estado.

Nesse sentido, como se percebe, trata-se de um tributo vinculado, porque, diferentemente dos impostos, sua cobrança depende, necessariamente, de uma atuação estatal referida ao contribuinte. É, portanto, um tributo vinculado de referibilidade direta (ao obrigado), já que a sua hipótese de incidência é a própria atuação estatal (ato de polícia ou serviço público) direta e imediatamente referida ao obrigado ${ }^{289}$, e não um benefício que esta possa trazer ao administrado.

A importância de se entender a repartição das competências tributárias por meio da vinculação ou não do poder público é lembrada por Geraldo Ataliba. Afirma o autor que, inversamente do que ocorre com os impostos, não existe a necessidade de a Constituição discriminar competências para a exigência das taxas, porque, como a hipótese de incidência é sempre uma atuação estatal, o ente público competente para desempenhar aquela função, e somente ele, é competente para legislar sobre sua atividade e colocar essa atuação no núcleo da hipótese de incidência.

Sob a ótica do Direito Financeiro, a distinção entre taxa e imposto consiste em que ambos são processos de repartição dos custos da atividade estatal entre os membros da coletividade. No entanto, enquanto o imposto opera a divisão dos encargos governamentais por grupos mais alargados, que tenham capacidade econômica de pagá-lo, sem a mínima preocupação de que os indivíduos neles integrados sejam ou não beneficiados, a taxa, ao contrário, divide a despesa apenas entre os indivíduos componentes do grupo limitado dos beneficiários diretos da atividade estatal (quer usem efetivamente o serviço, quer o tenham à sua disposição) ${ }^{290}$.

Nesse sentido, aqui não cabe falar em capacidade contributiva da mesma forma vista, anteriormente, nos impostos. Os critérios que informam essa espécie tributária são outros. Como a taxa deve custear o serviço público, tem caráter remuneratório da atuação do Poder Público e deve manter razoável equivalência com a despesa por ele efetuada. ${ }^{291}$, daí se dizer que as taxas devem obediência ao princípio da equivalência.

A Constituição traz duas hipóteses de taxa: a primeira pelo exercício do poder de polícia e a segunda, em razão de serviço público, ou melhor, pela utilização, efetiva ou

\footnotetext{
${ }^{289}$ ATALIBA, Geraldo. Hipótese de incidência tributária. 8. ed. São Paulo: Malheiros, 2008, p. 156;

${ }^{290}$ Ibidem, p. 173;

${ }^{291}$ COSTA, Regina Helena. Princípio da capacidade contributiva. op. cit., p. 57.
} 
potencial, de serviços públicos específicos e divisíveis, prestados ao contribuinte ou postos à sua disposição.

O poder de polícia a que se refere o dispositivo constitucional deve ser entendido de acordo com o CTN, mais precisamente o art. 78.

\footnotetext{
"Art. 78. Considera-se poder de polícia atividade da administração pública que, limitando ou disciplinando direito, interesse ou liberdade, regula a prática de ato ou abstenção de fato, em razão de interesse público concernente à segurança, à higiene, à ordem, aos costumes, à disciplina da produção e do mercado, ao exercício de atividades econômicas dependentes de concessão ou autorização do Poder Público, à tranquilidade pública ou ao respeito à propriedade e aos direitos individuais ou coletivos.

Parágrafo único. Considera-se regular o exercício do poder de polícia quando desempenhado pelo órgão competente nos limites da lei aplicável, com observância do processo legal e, tratando-se de atividade que a lei tenha como discricionária, sem abuso ou desvio de poder."
}

Podemos afirmar, então, que a taxa de polícia, no fundo, visa ao próprio bem comum, uma vez que existem certos direitos cujo exercício deve ser conciliado com o interesse público e, assim, cabe ao Estado policiar a atuação do cidadão. Construções civis, de modo geral, a instalação de uma empresa, são situações em que a Administração Pública deve verificar o cumprimento das normas pertinentes e, obedecidas tais normas, conceder a autorização, licença ou alvará. ${ }^{292}$

Nesse sentido, a taxa de polícia é cobrada em razão da atividade do Estado, que fiscaliza, verifica o cumprimento das exigências legais pertinentes, confere se o indivíduo está em conformidade com o que o próprio Estado determinou por meio das leis. Dessa forma, a atuação do Estado visa ao interesse da coletividade e não, ao do contribuinte ${ }^{293}$, isoladamente, por isso a afirmação de que, no fundo, essa taxa visa ao próprio bem comum.

Cabe deixar claro que, como é o próprio contribuinte quem provoca o Estado, porque solicita a fiscalização para que o Estado ateste se ele está em conformidade com a legislação pertinente, por consequência, é ele, contribuinte, quem terá de arcar com os custos daquela fiscalização.

Já as taxas de serviço estão disciplinadas no art. 79 do CTN.

“Art. 79. Os serviços públicos a que se refere o artigo 77 consideram-se:

I - utilizados pelo contribuinte:

${ }^{292}$ AMARO, Luciano. Op. cit., p. 55.
${ }^{293}$ Ibidem. 


\begin{abstract}
a) efetivamente, quando por ele usufruídos a qualquer título;
b) potencialmente, quando, sendo de utilização compulsória, sejam postos à sua disposição mediante atividade administrativa em efetivo funcionamento;

II - específicos, quando possam ser destacados em unidades autônomas de intervenção, de utilidade, ou de necessidades públicas;

"III - divisíveis, quando suscetíveis de utilização, separadamente, por parte de cada um dos seus usuários."
\end{abstract}

Importante lembrar a explicação didática do art. 80 do CTN, que, ratificando a ideia que já havíamos colocado quando tratamos da competência tributária, as taxas, tanto as cobradas pelo exercício regular do poder de polícia, quanto as de serviço, apenas são legítimas no âmbito da competência material do ente político.

As taxas de serviço devem ser cobradas por serviços divisíveis e específicos. Dessa simples constatação, que podemos extrair do dispositivo legal, já podemos verificar, mais uma vez, a diferenciação dessas em relação aos impostos. Segurança nacional, financiamento dos poderes da República, precisamente por serem indivisíveis e atenderem a todos os indivíduos do País, não podem ser objeto de taxa e, assim, obrigatoriamente, devem ser financiados por meio dos impostos.

A questão da fruição potencial, que poderia dar margem à interpretação de utilização obrigatória, não nos parece ser a mais adequada. Como assevera Luciano Amaro, a fruição potencial não está relacionada com a obrigatoriedade de utilização do serviço, nem com o descumprimento da obrigação que imponha essa utilização. ${ }^{294}$

Ruy Barbosa Nogueira corrobora com essa linha de pensamento e, para nós, fornece exemplo que parece elucidar a questão. Afirma o autor que a utilização efetiva ou potencial está vinculada à utilização do serviço pelo contribuinte. Dessa forma, para o Poder Público poder cobrar a taxa, é necessário que o serviço esteja efetivamente funcionando, porém, mesmo que o contribuinte não se utilize do serviço, tem a obrigação de contribuir para a sua manutenção, pois o serviço está à sua disposição. Ainda fornece como exemplo a célebre situação do cidadão que opta por não utilizar o serviço de distribuição de água encanada porque prefere utilizar a água proveniente de um poço que tem em sua propriedade. $\mathrm{O}$ fato de o cidadão não utilizar aquele serviço, que está a sua disposição, não o exime de arcar com a taxa de manutenção do serviço. ${ }^{295}$

Outra importante norma constitucional que diz respeito às taxas é a do art. 145, $\S 2^{\circ}$, ao estabelecer que as elas não poderão ter base de cálculo própria dos impostos. Iremos retornar ao tema da base de cálculo mais adiante.

\footnotetext{
${ }^{294}$ Ibidem, p. 58.

${ }^{295}$ NOGUEIRA, Ruy Barbosa. Op. cit., p. 163.
} 


\title{
5.1.3 Contribuições
}

A Constituição Federal prevê algumas modalidades de contribuições, indicadas no caput do art. 149 , assim redigido:

\begin{abstract}
"Art. 149. Compete exclusivamente à União instituir contribuições sociais, de intervenção no domínio econômico e de interesse das categorias profissionais ou econômicas, como instrumento de sua atuação nas respectivas áreas, observado o disposto nos arts. 146, III, e 150, I e III, e sem prejuízo do previsto no art. 195, § $6^{\circ}$, relativamente às contribuições a que alude o dispositivo.

$(\ldots)$ ")
\end{abstract}

As contribuições previstas nesse dispositivo recebem da doutrina as mais variadas denominações, mas aqui serão designadas de contribuições especiais, quando tratadas de forma genérica.

Paulo Ayres Barreto afirma que as contribuições, pelo simples exame do critério material da regra-matriz de incidência tributária, não têm como ser diferenciadas dos impostos. 296

Para José Eduardo Soares de Melo, as contribuições constituem tributos de características específicas, vinculados à despesa especial ou vantagem referida aos contribuintes e podem ou não implicar atuação estatal. ${ }^{297}$

Roque Carrazza é mais enfático e assevera que o dispositivo constitucional que trata das contribuições não apontou as suas regras-matrizes, apenas indicou as finalidades que devem atingir. ${ }^{298}$

Essas ideias servem apenas para ilustrar como é conturbada a questão de se tentar caracterizar as contribuições com base no seu aspecto material, ou mesmo impossível para alguns. Sem ingressar nas inúmeras discussões que o tema suscita, temos como traço peculiar das contribuições especiais (que abrangem as sociais, as de intervenção no domínio econômico e as de interesse de categoria profissional ou econômica) a vinculação da respectiva receita a finalidades predeterminadas, ou seja, a circunstância de o produto de sua arrecadação ser destinado, por lei, para emprego em fins

\footnotetext{
${ }^{296}$ BARRETO, Paulo Ayres. Contribuiçães: regime jurídico, destinação e controle. São Paulo: Noeses, 2006, p. 69.

${ }^{297}$ MELOR, José Eduardo Soares de . Contribuições sociais no sistema tributário. $6^{\mathrm{a}}$ ed., São Paulo: Malheiros Editores, 2010, p. 98.

${ }^{298}$ Op. cit., p. 592.
} 
específicos e não para qualquer objetivo ${ }^{299}$. É o caso, por exemplo, das contribuições a que se refere o art. 195 da $\mathrm{CF} / 1988$, cobradas de empregados e empregadores com o fim específico de financiar as despesas da seguridade social.

Segundo Alfredo Augusto Becker, nenhuma influência exerce sobre a natureza jurídica do tributo a circunstância de ele ter uma destinação determinada ${ }^{300}$. Tal assertiva se mostra verdadeira no que tange à natureza jurídica do tributo enquanto gênero (natureza jurídica genérica do tributo): a circunstância de o produto da arrecadação das contribuições especiais possuir destinação específica não retira delas a condição de tributo, até porque tal aspecto não foi considerado na conceituação legal do instituto, art. $3^{\circ}$, CTN. Por outro lado, com a atual Constituição e as atuais espécies tributárias, a circunstância de o tributo ter uma destinação determinada (ou não) é relevante para a definição de sua natureza jurídica específica, a despeito do que dispõe o inciso II do art. $4^{\circ}$ do CTN. ${ }^{301}$

Então, o art. 149 traz três subespécies de contribuiçõos especiais: as sociais, as de interesse das categorias profissionais ou econômicas e as de intervenção no domínio econômico. Essas são as que mais nos interessam, sem dúvida.

Estêvão Horvath afirma que as características essenciais das CIDEs são a finalidade e o destino do produto da sua arrecadação. ${ }^{302}$ A finalidade está relacionada, diretamente, à intervenção no domínio econômico, em última análise, não é qualquer intervenção que será tida como constitucional, mas é necessário que a intervenção seja compatível com o que determina a própria ordem econômica. Portanto, é necessário que a imposição interventiva vise a algum dos princípios inseridos no art. 170, e, por consequência, o produto da sua arrecadação seja investido naquela finalidade.

Em relação à estrutura das contribuições de interventivas, a materialidade possível não vem indicada diretamente no texto constitucional. Qualquer fato com conteúdo econômico poderá mostrar-se como critério material da norma impositiva. ${ }^{303}$

\footnotetext{
${ }^{299}$ Nesse sentido: No entender de Ruy Barbosa Nogueira, as "contribuições parafiscais" (denominação que utiliza para designar as contribuições do art. 149 da CF/1988) são tributos, mas não constituem espécie tributária autônoma: "Como a natureza específica de cada tributo é determinada pelo fato gerador da respectiva obrigação $\left(\mathrm{CTN}\right.$, art. $\left.4^{\circ}{ }^{\circ}\right)$, é o exame do fato gerador de cada espécie de contribuição que poderá demonstrar, em cada caso, se se trata de um imposto, de uma taxa ou de consorciação dessas duas categorias" (grifo no original). Curso de direito tributário. op. cit., p. 177-178.

${ }^{300}$ BECKER, Alfredo Augusto. Teoria geral do direito tributário. 4. ed. São Paulo: NOESES, 2007, p. 304.

${ }^{301} \mathrm{CTN}$, art. 4": "A natureza jurídica específica do tributo é determinada pelo fato gerador da respectiva obrigação, sendo irrelevantes para qualificá-la: (...) II - a destinação legal do produto da sua arrecadação".

${ }^{302}$ HORVATH, Estêvão. Contribuições de intervenção no domínio econômico. São Paulo: Dialética, 2009, p. 45.

303 PIMENTA, Paulo Roberto Lyrio. Contribuições de intervenção no domínio econômico. São Paulo: Dialética, 2002, p.60
} 
Ricardo Conceição Souza, ao estabelecer que contribuição não é imposto, trata de espécies autônomas e, assim, a norma do art. $145, \S_{1}^{\circ}$ da $\mathrm{CF} / 88$, capacidade contributiva, não se aplica às contribuições. Mas reconhece, exatamente por se tratar de tributo, que ele não pode ser utilizado com efeito de confisco, de forma que o art. 150, IV, da $\mathrm{CF} / 88$ deve ser aplicado. ${ }^{304}$

Paulo Ayres Barreto, ao analisar o problema dos limites das contribuições, salienta que, quando a norma instituidora da contribuição eleger um critério material típico de imposto, a divisão do encargo ou despesa dentro do grupo pode ser feita segundo a escolha de uma base de cálculo que atenda à própria capacidade contributiva e reflita a forma mais adequada de partilhar a despesa, conjuntamente. ${ }^{305}$

No entanto, quando o critério eleito não atende, necessariamente, à capacidade contributiva, ele deverá ser analisado à luz dos princípios da proporcionalidade e da razoabilidade. Caso tal critério passe por esses exames, não se há de censurá-lo. Paulo Ayres ainda defende que, como a equidade na forma de participação no custeio foi expressamente prevista para as contribuições destinadas à seguridade social, tal critério também deveria ser observado nas demais contribuições, visto que se trata de decorrência natural da eleição de um adequado critério para a repartição do custeio da atividade. ${ }^{306}$

\subsubsection{Outras espécies}

Já mencionamos, no início desse capítulo, que somos adeptos da classificação quinquipartida das espécies tributárias. No entanto, por entendermos que as espécies já tratadas são as que possuem maior potencial para se configurarem como tributos ecológicos, debruçamo-nos sobre elas primeiro. Iremos analisar, agora, os empréstimos compulsórios e as contribuições de melhoria, duas espécies que, em nosso entendimento, têm um baixo potencial para se configurarem como tributos ecológicos.

As contribuições de melhoria, assim como as taxas, não encontram uma definição expressa em nosso ordenamento jurídico.

No entanto, alguns textos normativos podem ser utilizados como subsídio para a elaboração de um conceito. Referimo-nos ao art. 145, III, da Constituição Federal, e ao art. 81 do Código Tributário Nacional, que dispõem:

\footnotetext{
${ }^{304304}$ SOUZA, Ricardo Conceição. Regime jurídico das contribuições. São Paulo: Dialética, 2002, p. 114. 305 BARRETO, Paulo Ayres. Op. cit., p. 144.

306 Ibidem, 145.
} 
“Art. 145. A União, os Estados, o Distrito Federal e os Municípios poderão instituir os seguintes tributos:

(...)

III - contribuição de melhoria, decorrente de obras públicas.

Art. 81. A contribuição de melhoria cobrada pela União, pelos Estados, pelo Distrito Federal ou pelos Municípios, no âmbito de suas respectivas atribuições, é instituída para fazer face ao custo de obras públicas de que decorra valorização imobiliária, tendo como limite total a despesa realizada e como limite individual o acréscimo de valor que da obra resultar para cada imóvel beneficiado."

Da leitura dos dispositivos transcritos, podemos definir a contribuição de melhoria como o tributo que tem por hipótese tributária a construção de obra pública da qual decorra a valorização de imóvel particular ${ }^{307}$ ou, em outras palavras, a valorização de imóvel particular em decorrência de obra pública.

Observa-se, pelo conceito formulado, que a contribuição de melhoria, da mesma maneira que as taxas, é um tributo vinculado, sendo, pois, regida pelo princípio da retributividade, já que sua cobrança exige como pressuposto a realização de uma atividade estatal dirigida ao sujeito passivo - no caso, a construção de uma obra pública.

No entanto, difere das taxas, por ser um tributo vinculado de referibilidade indireta, ao obrigado, porque a sua hipótese tributária não é a mera atuação estatal, no caso, a obra pública, e, sim, um benefício que esta possa trazer ao administrado, a valorização imobiliária $^{308}$

A contribuição de melhoria, como a taxa, efetua a divisão do custo da atividade estatal específica, construção da obra pública, apenas entre os indivíduos componentes do grupo limitado dos beneficiários daquela atividade, proprietários de imóveis, cuja valorização decorreu da obra pública ${ }^{309}$. A referida exação tem como limite total a despesa

\footnotetext{
${ }^{307}$ Somente a valorização de imóveis de propriedade privada enseja a cobrança de contribuição de melhoria (arts. $2^{\circ}$ e $3 .^{\circ}, \S 3 .^{\circ}$, ambos do Decreto-Lei n. 195, de 27.2.1967).

${ }^{308}$ PIRES, Adilson Rodrigues. Manual de direito tributário. 9. ed. Rio de Janeiro: Forense, 1996, p. 27.

Em sentido contrário, Sacha Calmon Navarro Coelho entende que a circunstância de o inciso III do art. 145 da Constituição de 1988 não ter mencionado a "valorização" significaria ter o Texto Constitucional optado pela "contribuição de melhoria tipo custo", assim entendida a que leva em conta, tão somente, o valor (custo total) da obra pública, tendo desaparecido, por conseguinte, a contribuição de melhoria recuperadora da "mais-valia imobiliária", assim entendida a que toma em conta a valorização dos imóveis situados na área de influência da obra pública. In: Curso de direito tributário brasileiro. Rio de Janeiro: Forense, 2009, p. 413414).

309 Nesse sentido, é o disposto no §2. ${ }^{\circ}$ do Decreto-Lei 195/1967: “A determinação da Contribuição de Melhoria far-se-á rateando, proporcionalmente, o custo parcial ou total das obras, entre todos os imóveis incluídos nas respectivas zonas de influência".
} 
realizada, isto é, o custo da obra, ${ }^{310}$ e como limite individual, o acréscimo de valor que da obra resultar para cada imóvel beneficiado, art. 81, CTN.

A competência para instituir essa espécie de cobrança é de todos os entes da Federação, como já vimos. Ocorre que, quando falamos de tributação ecológica, as possibilidades para o uso de tal instrumento ficam limitadas, para não dizer impossíveis. Como já vimos, trabalhamos com um tipo de tributo ecológico que visa a incidir sobre a própria poluição e se a hipótese tributária das contribuições de melhoria, obrigatoriamente, é a valorização imobiliária em decorrência de obra pública, não há espaço para tributação ecológica nessa espécie.

Mesmo que se argumentasse sobre a construção de uma obra pública, cujo propósito fosse a limpeza das águas, o tratamento de esgoto, ou outras melhorias para a população, ainda assim, estaríamos diante de valorização imobiliária decorrente de obra pública e não de poluição. Nesse caso, até poderíamos defender que a obra pública foi ambientalmente orientada e, por consequência, esse tributo também seria ambientalmente orientado, mas não se confundiria com a tributação da poluição.

Os empréstimos compulsórios são tributos que somente podem ser instituídos pela União, mediante lei complementar, em caso de calamidade pública, de guerra externa ou sua iminência, art. 148, I, CF/88, ou no caso de investimento público de caráter urgente e de relevante interesse nacional, art. 148, II, CF/88. Esses tributos serão suprimidos gradativamente quando cessadas as causas de sua criação, após o que deverão ser restituídos. Assim, caracterizam-se os empréstimos compulsórios pela exigência constitucional de previsão legal de devolução do montante do tributo ao contribuinte ao fim de determinado período ${ }^{311}$.

\footnotetext{
“Art. 148. A União, mediante lei complementar, poderá instituir empréstimos compulsórios:

I - para atender a despesas extraordinárias, decorrentes de calamidade pública, de guerra externa ou sua iminência;

II - no caso de investimento público de caráter urgente e de relevante interesse nacional, observado o disposto no art. 150, III, "b".

Parágrafo único. A aplicação dos recursos provenientes de empréstimo compulsório será vinculada à despesa que fundamentou sua instituição.”
}

\footnotetext{
${ }^{310} \mathrm{O}$ art. $4^{\circ}$ do Decreto-Lei 195/1967 explicita o que se deve entender como "custo da obra" e esclarece que nele se computam "as despesas de estudos, projetos, fiscalização, desapropriações, administração, execução e financiamento".

${ }^{311}$ MARQUES, Márcio Severo. Classificação constitucional dos tributos. São Paulo: Max Limonad, 2000, p. 192.
} 
Importante destacar que parte renomada da doutrina entende que os empréstimos compulsórios não são uma espécie tributária autônoma e, na verdade, trata-se de um imposto ${ }^{312}$, ou até mesmo que o empréstimo compulsório pode revestir qualquer das formas tributárias, imposto, taxa ou contribuição de melhoria. ${ }^{313}$

Alfredo Augusto Becker entende que nenhuma influência exerce sobre a natureza jurídica do tributo a circunstância de ele ser ou não ser, mais tarde, devolvido ao contribuinte. $^{314}$

Realmente, não há o que se discutir acerca de tal assertiva no que tange à natureza jurídica do tributo enquanto gênero, isto é, a circunstância de o empréstimo compulsório ser restituível não retira dele a condição de tributo, até porque tal aspecto não foi considerado na conceituação legal de tributo, art. $3^{\circ}, \mathrm{CTN}^{315}$.

Porém, a circunstância de o tributo ser ou não ser devolvido ao contribuinte é relevante para a determinação de sua natureza jurídica específica. Nesse sentido, é a observação feita por Eurico Marcos Diniz de Santi, quando assinala que, se por um lado é útil para a classificação das espécies tributárias, por outro lado, é de todo irrelevante a destinação legal ou financeira quando se pretende qualificar uma prestação como tributo ou não. ${ }^{316}$

Ainda, a aplicação dos recursos provenientes da cobrança de empréstimos compulsórios é vinculada à despesa extraordinária que fundamentou sua instituição, consoante determina o parágrafo único do art. 148 da $\mathrm{CF} / 88$. A lei complementar que instituir o empréstimo compulsório deve fixar obrigatoriamente o prazo do empréstimo e as condições de seu resgate, art. 15, parágrafo único, CTN.

Não nos parece que esse tributo tenha condições de servir como instrumento para tributar a poluição, visto que se trata de um tributo excepcional e provisório. A própria Constituição, ao prever diante de quais situações a União poderia instituir esse tributo, em razão das próprias situações que elencou no texto constitucional, deixou claro que se trata de tributo momentâneo, decorrente de uma situação extrema, de guerra ou sua iminência, imprevisível ou urgente. Todas essas situações demonstram o caráter da

\footnotetext{
${ }^{312}$ BECKER, Alfredo Augusto. Op. cit., p. 417.

${ }^{313}$ CARVALHO, Paulo de Barros. Curso de direito tributário. 19a ed., São Paulo: Saraiva, 2007, p. 33.

${ }^{314}$ BECKER, Alfredo Augusto. Op. cit., p. 304.

${ }^{316}$ SANTI, Eurico Marcos Diniz de. As classificações no sistema tributário brasileiro. In: Justiça tributária: direitos do fisco e garantias dos contribuintes nos atos da administração e no processo tributário. São Paulo: Max Limonad, 1998, p. 143.
} 
excepcionalidade, de modo que nenhuma dessas situações pode ser entendida como ordinária ou corriqueira.

Portanto, o combate à poluição não ser entendido como excepcional e, sim, como uma política institucionalizada. Para nós, apenas essa razão já inviabilizaria a possibilidade de utilizarmos os empréstimos compulsórios como um mecanismo para combater a poluição.

Mas existe outra razão, que parece ser mais antagônica ainda. Imaginemos que ocorreu uma catástrofe ambiental, a União não tinha recursos suficientes disponíveis e decidiu instituir um empréstimo compulsório. Este empréstimo terá no seu aspecto material a própria poluição, a emissão de monóxido por empresas. Em tese, esse empréstimo, já que está incidindo sobre a poluição, seria considerado ecológico. No entanto, ele não pretende combater poluição alguma, tampouco será revertido para o combate de alguma espécie de poluição. E o que nos parece mais grave, no que diz respeito ao meio ambiente, aquele valor cobrado do indivíduo, porque ele poluiu, passada a causa da instituição, o tributo será devolvido. Será devolvido por determinação legal.

Ora, nessa situação hipotética, não haverá benefício algum para o meio ambiente. A União apenas utilizou uma materialidade que lhe pareceu rentável naquele momento, mas, nesse caso, o tributo possuía nítidos interesses fiscais, em nada contribuindo, ou visando à mudança de comportamentos ecologicamente degradantes ou incorretos.

\subsection{HIPÓTESE TRIBUTÁRIA DO TRIBUTO ECOLÓGICO}

Antes de analisarmos a situação hipotética que caracteriza um tributo ecológico, é importante termos condições de distinguir diante de qual espécie tributária nos encontramos.

Nesse sentido, primeiramente precisamos identificar se uma determinada receita pública possui natureza tributária. Para tal fim, basta confrontá-la com o conceito legal de tributo, art. $3^{\circ}$, CTN. Se feito tal confronto, a receita analisada adequar-se ao conceito em questão ter-se-á tributo; caso contrário, não se tratará de receita tributária e se escapará, por conseguinte, do regime jurídico próprio das normas tributárias, como é o caso das multas, uma vez que estas não se confundem com receita tributária, porque constituem sanção por ato ilícito. 
Mas não basta identificar se é tributo. Cuida-se de identificar a natureza jurídica específica do tributo, a espécie tributária. O CTN fornece, em seu art. 4. ${ }^{\circ}$, alguns critérios para a determinação de tal natureza.

\footnotetext{
"Art. $4^{\circ}$. A natureza jurídica específica do tributo é determinada pelo fato gerador da respectiva obrigação, sendo irrelevantes para qualificá-la:

I - a denominação e demais características formais adotadas pela lei;

II - a destinação legal do produto da sua arrecadação."
}

Percebe-se, pela redação do dispositivo legal, que ele indica um único fator a ser levado em consideração para determinar a natureza jurídica específica do tributo: o fato gerador da obrigação ${ }^{317}$.

Todavia, para deixar clara sua ideia, o legislador estatuiu, ainda, serem irrelevantes para a definição da natureza jurídica específica do tributo: a) a denominação e outras características formais adotadas pela lei; e b) a destinação legal do produto da arrecadação do tributo.

Quanto ao nomen juris do tributo, parece-nos evidente a sua irrelevância para a determinação da natureza jurídica específica do tributo, porque, como ressalta Aliomar Baleeiro, não poderia ter efetividade nem sobrevivência o sistema tributário instituído pela Constituição, se se permitisse "ao legislador ordinário iludi-lo, pela troca dos nomes de cada tributo, para invasão do campo tributário reservado a competência diversa." 318

Assim, a circunstância de um tributo receber do legislador determinada designação juridicamente nada significa, já que, nos termos do inciso I do art. $4^{\circ}$ do CTN, é irrelevante a impropriedade técnica do nomen juris eventualmente adotado ${ }^{319}$.

É precisamente a situação relatada por Jorge Hernández, ao obervar que, na Espanha, apesar de os tributos ecológicos terem de ser configurados como uma das três

\footnotetext{
${ }^{317}$ Importante ressaltarmos a explicação dada por Schoueri a respeito da expressão fato gerador, "que o Código Tributário Nacional, e até mesmo a Constituição Federal, utilizam a expressão "fato gerador" para referir-se tanto à circunstância abstrata, definida pelo legislador (a qual parte da doutrina vem denominando "hipótese de incidência", ou "hipótese tributária"), quanto a cada um dos fatos concretos, que correspondem àquela hipótese (o chamado "fato imponível", ou "fato jurídico tributário"). Do ponto de vista lógico, são coisas diversas: a hipótese é abstrata; o fato é concreto. (...) Assim, ao se ler um texto legal ou doutrinário, deve-se tomar o cuidado de investigar se a expressão "fato gerador" está sendo empregada em seu sentido abstrato ou concreto." Luís Eduardo Schoueri, Direito tributário, op. cit., p. 426.

${ }^{318}$ BALEEIRO, Aliomar. Direito tributário brasileiro. 11. ed. Atualizado por Misabel Derzi. Rio de Janeiro: Forense, 2009, p. 64.

${ }^{319}$ A denominação é irrelevante até mesmo no processo para identificar se uma dada receita pública possui natureza tributária ou não. O fato de uma lei designar de "preço público" ou "tarifa" o que, em verdade, configura taxa, não tem o condão de modificar a natureza da receita em questão, com o que, se fosse juridicamente possível tal alteração, escaparia a exação das limitações constitucionais impostas ao poder de tributar.
} 
espécies tributárias previstas na Lei Geral Tributária espanhola, imposto, taxa ou contribuição especial, os legisladores espanhóis atribuem a alguns tributos ecológicos o nome de "cânones", que não possui um conteúdo terminológico preciso dentro da terminologia tributária e, em geral, embora não seja diferente de nenhuma daquelas três espécies, já gerou inúmeras confusões. ${ }^{320}$

Feitas tais considerações acerca do nomen juris do tributo, veremos o sentido de fato gerador, conforme disposto no art. $4 .^{\circ}$ do CTN.

Dispõe o Código que o fato gerador é o único elemento que importa para o fim de definição da natureza jurídica específica do tributo. Tal assertiva será correta se for considerado igualmente correto o disposto no art. $5 .^{\circ}$ do CTN, segundo o qual os tributos são, apenas, impostos, taxas e contribuição de melhoria.

A expressão fato gerador, que aparece no art. $4 .^{\circ}$ do $\mathrm{CTN}$, faz referência à hipótese tributária. Com efeito, para distinguir cada uma das referidas espécies de tributos das demais, é a hipótese tributária o elemento diferenciador: se o tributo analisado tiver por hipótese tributária uma situação de fato que se refira exclusivamente à pessoa do obrigado e à sua esfera de atividade, independentemente de qualquer atividade estatal específica referida ao contribuinte, ter-se-á imposto, conforme art. 16 do CTN; se o tributo em questão tiver por hipótese tributária o exercício do poder de polícia ou a prestação ou disponibilidade de um determinado serviço público específico e divisível, ter-se-á taxa, art. 145, II, CF/1988; art. 77, CTN; se o tributo tiver por hipótese tributária a valorização de imóvel particular em decorrência da construção de determinada obra pública, ter-se-á contribuição de melhoria art. 145, II, CF/1988; art. 81, CTN.

Ocorre que, como já visto, os impostos, as taxas e as contribuições de melhoria não são as únicas espécies tributárias existentes no ordenamento brasileiro, que também confere natureza tributária aos empréstimos compulsórios, art. 148, CF/88, e às contribuições especiais, art. 149, CF/88. A hipótese tributária não se mostra critério eficaz para diferenciá-las, já que tais espécies tributárias não se distinguem das demais pelas respectivas hipóteses, que, aliás, sequer são mencionadas no Texto Constitucional. ${ }^{321}$ Para identificar tais espécies, o elemento determinante é, apesar do que dispõe o inciso II do art. 4. ${ }^{\circ}$ do CTN, a destinação do produto de sua arrecadação.

\footnotetext{
${ }^{320}$ HERNÁNDEZ, Jorge Jiménez. El tributo como instrumento de protección ambiental. Granada, Editorial Comares, S.L., 1998, p. 126-127.

${ }^{321}$ É por esta razão que preferimos não enquadrar as referidas espécies exacionais na classificação doutrinária que divide os tributos em vinculados e não vinculados, porquanto entendemos que o fato gerador das contribuições especiais e dos empréstimos compulsórios pode ou não estar vinculado a alguma atividade estatal.
} 
Ocorre que a norma em comento somente faz sentido no universo vislumbrado pelo CTN, em que somente existiriam as três espécies tributárias mencionadas em seu art.

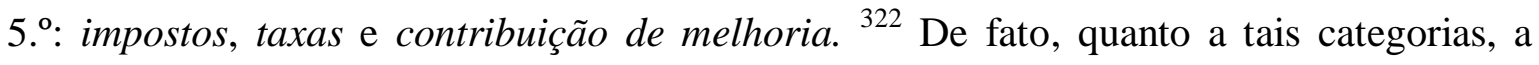
hipótese tributária é suficiente para distingui-las umas das outras. Mas essa realidade não corresponde mais à realidade jurídica de nosso sistema.

Feitas tais considerações, agora já podemos identificar diante de qual espécie tributária nos encontramos e podemos analisar os elementos ou aspectos que compõem a norma tributária e analisar qual seria, efetivamente, a espécie tributária mais adequada para servir de veículo para um tributo ecológico.

Ressalte-se que não pretendemos esmiuçar as teorias da norma, especificamente da norma tributária, tampouco esgotar as questões a respeito da hipótese tributária. Como estamos trabalhando com um típico tributo ecológico, iremos apenas analisar como esse tributo se comporta em nosso ordenamento. Mas, para isso, mesmo que de forma breve, precisamos analisar os elementos que compõem a norma tributária e tornam possível a imposição tributária e a sua respectiva cobrança.

Convém lembrar que a Constituição não cria tributos, tão somente discrimina competências para que as pessoas políticas, por meio de lei, art. 150, I, CF/88, venham a fazê-lo. ${ }^{323}$ No entanto, ao traçar o contorno das competências tributárias, a Constituição estabelece limites precisos, de modo que as pessoas políticas - União, Estados, Distrito Federal e Municípios - no exercício de suas competências, com a edição da lei veiculadora da norma jurídica tributária, obedeçam aos limites constitucionais.

Para Paulo de Barros Carvalho, "regra-matriz de incidência tributária" deve ser entendida como a norma jurídica tributária que veicula um determinado tributo. ${ }^{324}$

A regra-matriz de incidência tributária é composta de uma hipótese (antecedente) a que se conjuga um mandamento (consequente). $\mathrm{O}$ antecedente da endonorma tributária é o conjunto de critérios para reconhecimento de um fato lícito (capaz de fazer nascer uma relação jurídica tributária), ao passo que o consequente da endonorma tributária é o conjunto de critérios para identificação da relação jurídica que se

\footnotetext{
${ }^{322}$ PINTO, Flávia Sousa Dantas. Regra-matriz das contribuições: uma proposta. In: MARTINS, Ives Gandra da Silva; ELALI, André (coord.) Elementos atuais de direito tributário: estudos e conferências. Curitiba: Juruá, 2005, p. 216-217.

${ }^{323}$ Roque Antonio Carrazza observa que a Constituição estabelece apenas o "arquétipo" dos tributos: "Noutros termos, ela apontou a hipótese de incidência possível, o sujeito ativo possível, o sujeito passivo possível, a base de cálculo possível e a alíquota possível, das várias espécies e subespécies de tributos" (grifos no original), Curso de direito constitucional tributário. 25. ed. São Paulo: Malheiros, 2009, p. 516.

${ }^{324}$ CARVALHO, Paulo de Barros. Curso de direito tributário. 19. ed. São Paulo: Saraiva, 2007, p. 259.
} 
instaura entre o Estado, em geral, na qualidade de sujeito ativo, e alguma pessoa física ou jurídica, na condição de sujeito passivo, tendo por objeto o dever de pagar tributo. ${ }^{325}$

Para Geraldo Ataliba, hipótese de incidência tributária é uma descrição legislativa, necessariamente hipotética, de um fato cuja ocorrência real, in concretu, a lei atribui a força jurídica de determinar o nascimento da obrigação tributária. ${ }^{326}$ Segundo Ataliba, a hipótese de incidência possui os seguintes aspectos essenciais: a) aspecto pessoal; b) aspecto material; c) aspecto espacial; d) aspecto temporal. ${ }^{327}$

No entanto, no presente trabalho, apenas para essa momentânea análise dos aspectos que compõem a norma instituidora de tributos, adotamos a sistematização proposta por Paulo de Barros Carvalho. A presente ressalva é importante porque depois continuaremos a adotar a expressão hipótese jurídico-tributária. Carvalho entende possuir a hipótese de incidência tributária, isto é, o antecedente da norma tributária, apenas três critérios $^{328}$ : a) critério material; b) critério temporal; c) critério espacial. Já o mandamento, consequente, da endonorma tributária, possuiria os seguintes critérios: a) critério pessoal; b) critério quantitativo ${ }^{329}$.

Nos itens que seguem, serão analisados, em linhas gerais, os aspectos que compõem cada uma das partes da norma jurídica tributária que integram o antecedente e o consequente da regra-matriz de incidência.

A hipótese de incidência tributária indica um acontecimento que, se e quando ocorrido, irá deflagrar os efeitos previstos na própria norma jurídica.

$\mathrm{Na}$ hipótese (antecedente) da norma tributária, consoante leciona Paulo de Barros Carvalho, encontraremos um critério material, descrição do comportamento de uma pessoa, condicionado no tempo, critério temporal, e no espaço, critério espacial. ${ }^{330}$

$\mathrm{O}$ antecedente da norma tributária é composto pelos seguintes aspectos: a) material; b) temporal; c) espacial.

\footnotetext{
${ }^{325}$ CARVALHO, Paulo de Barros. Teoria da norma tributária. 3. ed. São Paulo: Max Limonad, 1998, p. 98. ${ }^{326}$ ATALIBA, Geraldo. Hipótese de incidência tributária. 6. ed. São Paulo: Malheiros, 2008, p. 76.

${ }^{327}$ Ob. cit. p. 78.

${ }^{328}$ Apesar de o autor citado empregar o termo "critérios" em substituição à expressão "aspectos", utilizada por Geraldo Ataliba, preferimos utilizar a expressão aspectos, apesar de estarmos adotando a classificação.

${ }^{329}$ CARVALHO, Paulo de Barros. Curso de direito tributário. op. cit., p. 285 e 313; idem, Teoria da norma tributária. op. cit., p. 124-178.

${ }^{330}$ CARVALHO, Paulo de Barros. Op. cit., p. 285.
} 


\subsubsection{ASPECTO MATERIAL}

É o aspecto mais importante e complexo da hipótese tributária. ${ }^{331} \mathrm{O}$ aspecto material, considerado o seu "núcleo", é o elemento objetivo da norma jurídica tributária e consiste na descrição dos acontecimentos que determinarão o nascimento da obrigação tributária $^{332}$, isto é, dos fatos capazes de motivar a atuação do poder tributante no sentido de uma exigência de prestação ${ }^{333}$.

Para Paulo de Barros Carvalho, a ação descrita no critério material é invariavelmente traduzida num verbo e num complemento. Com base nessa concepção, a hipótese reporta-se à ideia de comportamento humano, ou para refletir atividades, verbos que exprimam ação, ou espontaneidade, verbos de estado, ser, estar e outros. ${ }^{334}$

Para Geraldo Ataliba, é o aspecto mais importante, porque sua essência permite a caracterização e a individualização diante de todas as demais hipóteses de incidência. Com base nesse aspecto, pode-se fixar a espécie tributária a que o tributo pertence, porque as classificações jurídicas encontram critério e fundamento na configuração do aspecto material da hipótese de incidência. ${ }^{335} 336$

Em relação às contribuições de intervenção no domínio econômico, precisamente por não terem a sua materialidade delimitada pela Constituição, Marilene Rodrigues sustenta que o legislador ordinário não possui total liberdade, e que essas devem ter uma relação com a própria intervenção e com o grupo econômico, ${ }^{337}$ sendo dois os critérios materiais possíveis para as contribuições ${ }^{338}$ : a) obter vantagem em razão da atividade estatal realizada com vistas às finalidades constitucionalmente previstas; causar uma atividade estatal que será realizada com vistas às finalidades constitucionalmente previstas e ocasionará determinados resultados.

\footnotetext{
331 ATALIBA, Geraldo. op. cit., p. 106.

${ }^{332}$ NUNES, Vidal Serrano. Direito constitucional tributário. v. 1. São Paulo: Didática, s/d, p. 34.

${ }^{333}$ FANUCCHI, Fábio. Curso de direito tributário brasileiro. v. 1. São Paulo: Resenha Tributária, 1971, p. 116.

${ }^{334}$ CARVALHO, Paulo de Barros. Curso de direito tributário. op. cit., p. 289.

335 ATALIBA, Geraldo. op. cit., p. 107.

${ }^{336}$ Note-se que já firmamos posicionamento, que, na atual configuração do sistema tributário, a destinação da receita, ou melhor, a sua vinculação, também é critério fundamental para identificarmos a precisa espécie tributária.

337 RODRIGUES, Marilene Talarico Martins. Contribuições de intervenção no domínio econômico. In: MARTINS, Ives Gandra da Silva (coord.). Contribuições de intervenção no domínio econômico. São Paulo: Ed. Revista dos Tribunais: Centro de Extensão Universitária, 2002, p. 147.

338 Nesse sentido: HOFFMANN, Susy Gomes. As contribuições no sistema constitucional tributário. Campinas, SP: Copola, 1996, p. 136.
} 


\subsubsection{ASPECTO ESPACIAL}

O aspecto espacial da hipótese de incidência tributária consiste na descrição do local em que a lei considera ocorrido o fato jurídico tributário. Trata-se da descrição normativa do local em que a ação, indicada no critério material da norma tributária, deve ser praticada, para que o tributo seja devido.

Conforme a lição de Paulo de Barros Carvalho, o critério espacial das hipóteses tributárias indica os elementos que permitirão reconhecer a circunstância de lugar que limita, no espaço, a ocorrência daquele evento. ${ }^{339}$

As conotações espaciais da hipótese de incidência de um tributo são determinantes para a configuração do fato gerador daquele, posto que a hipótese de incidência só qualifica um fato como gerador, isto é, como hábil a determinar o nascimento de uma dada obrigação tributária, quando este se realize num determinado lugar ${ }^{340}$.

Alfredo Augusto Becker adota o termo "coordenadas de lugar", para afirmar que essas podem condicionar que o núcleo e os elementos adjetivos devam acontecer todos no mesmo lugar ou cada um em distintos lugares. ${ }^{341}$

Para Schoueri, o exame do aspecto espacial da norma traz reflexões sobre a existência de limites ao exercício da competência tributária, visto que, de um lado, a lei poderá definir seu âmbito de aplicação expressamente e, de outro, no silêncio dela, haverá, de qualquer modo, limite equivalente ao próprio âmbito de aplicação da lei tributária. ${ }^{342}$

Para demonstrar a importância do tema, sua complexidade e a relevância do elemento de conexão na fixação do aspecto espacial da hipótese tributária, o referido autor fornece o exemplo de um cidadão-contribuinte americano, residente na Noruega, aufere rendimentos decorrentes de um trabalho exercido na Alemanha, mas contratado por empresa francesa. ${ }^{343}$

A mesma espécie de conflito pode ser suscitada quando lidamos com a tributação da poluição, e não é raro de acontecer. Suponha-se que uma indústria instalada na cidade A, emita fumaça ou expila gases tóxicos, mas, por questões geográficas naturais, a cidade $\mathrm{A}$, sede da empresa, não sofre espécie alguma de poluição. Toda poluição atmosférica gerada pela empresa é levada pelos ventos até a cidade B e apenas lá causam

\footnotetext{
${ }^{339}$ CARVALHO, Paulo de Barros. Teoria da norma tributária. op. cit., p 130.

${ }^{340}$ ATALIBA, Geraldo. op. cit., p. 104-105.

${ }^{341}$ BECKER, Alfredo Augusto. op. cit., p. 352.

${ }^{342}$ SCHOUERI, Luís Eduardo. Direito tributário. op. cit., p. 450.

${ }^{343}$ Ibidem.
} 
os problemas ambientais e de saúde próprios desse tipo de poluição. Indaga-se: a cidade B teria condições de tributar aquela situação? Quem defende que o tributo pode ser cobrado no lugar onde foram sentidos os efeitos da poluição vai entender que sim.

Paulo Henrique do Amaral entende dessa forma, porque, para o autor, em matéria de tributos ambientais, devem ser adotados três critérios espaciais: a) o lugar onde ocorre o uso dos recursos naturais; b) a localidade onde as atividades poluidoras são desenvolvidas; e/ou c) os locais onde os efeitos da degradação ambiental são sentidos. ${ }^{344}$

Esse entendimento parece provocar algumas consequências bastante danosas, porque qualquer ente que entenda ser vítima dessa poluição, ou que alegue sofrer os efeitos de tal emissão poderá, em tese, tributar a mesma empresa, o que implicaria uma dupla tributação.

Não parece ser essa a melhor solução, até porque, quando lidamos com a voracidade fiscal do Estado, é preciso muita cautela. Nesse sentido, várias outras cidades que estão ao redor da empresa poderiam querer cobrar um tributo semelhante, o que poderia acarretar o próprio fechamento da empresa, já que teria de arcar com um número elevado de tributos.

\subsubsection{ASPECTO TEMPORAL}

O critério temporal da regra-matriz de incidência tributária é o que determina o momento em que se tem por acontecida a materialidade do tributo ${ }^{345}$.

Trata-se da descrição normativa do momento em que a ação, indicada no critério material da endonorma tributária, deve ser praticada, para que o tributo seja devido.

Geraldo Ataliba, ao analisar o tema, afirma que, independentemente de o ato qualificado pela lei se consumar num átimo ou se for dependente de penoso e lento processo pré-jurídico para se consumar, é relevante o momento da sua consumação, já que somente com ela o fato se torna fato jurídico, fato imponível. ${ }^{346}$

Paulo de Barros Carvalho noticia que os legisladores, erroneamente, passaram a dar nome de "fato gerador" de certos impostos ao critério temporal da hipótese de incidência estabelecido em lei. ${ }^{347}$

\footnotetext{
${ }^{344}$ AMARAL, Paulo Henrique do. Direito tributário ambiental. São Paulo: Revista dos Tribunais, 2007, p. 212.

${ }^{345}$ SILVA, Joana Lins e. Fundamentos da norma tributária. São Paulo: Max Limonad, 2001, p. 159.

${ }^{346}$ ATALIBA, Geraldo. op. cit., p. 103.

${ }^{347}$ CARVALHO, Paulo de Barros. Curso de direito tributário. op. cit.
} 
Constata-se o afirmado por Carvalho na redação do art. 19 do CTN, que, ao estabelecer normas gerais sobre o Imposto de Importação I.I., assim dispõe: "O imposto, de competência da União, sobre a importação de produtos estrangeiros tem como fato gerador a entrada destes no território nacional" (grifamos).

Tal redação, a pretexto de mencionar o "fato gerador" do imposto em questão, separa um dado instante, que não passa, contudo, de uma unidade coordenada de tempo, mesmo que representada por um acontecimento que sirva de simples referência. ${ }^{348}$

A legislação mais recente tem procurado superar essa deficiência, distanciando-se dessa técnica. Toma-se, como exemplo, a Lei Complementar n. 87, de 13.9.1996, que, ao estabelecer normas gerais em matéria de ICMS, separou em dois dispositivos distintos a descrição do aspecto material da hipótese de incidência do imposto, art. 2. ${ }^{\circ}$, e os critérios temporais de cada uma das suas hipóteses de incidência, art. 12, evitando, assim, a confusão do todo com a parte.

Enquanto o antecedente da norma tributária, a hipótese de incidência tributária, alude a um acontecimento, o consequente da norma prescreve os efeitos jurídicos que aquele acontecimento, se e quando ocorrido, irá propagar.

Assim, por exemplo, a hipótese de incidência do IPI traz a previsão de um fato, se alguém industrializar produtos, enquanto o consequente prescreverá a relação jurídica que se vai instaurar, aquele alguém - sujeito passivo - deverá pagar à Fazenda Federal sujeito ativo - determinado valor a título de IPI - que será obtido pela conjugação da base de cálculo e da alíquota do tributo em questão.

No consequente mandamento, $\backslash$ da norma tributária, encontraremos um aspecto pessoal, sujeito ativo e passivo, e um aspecto quantitativo, base de cálculo e alíquota. $^{349}$

O mandamento consequente da norma tributária é composto, portanto, pelos seguintes aspectos: a) pessoal; b) quantitativo. Vejamos, separadamente, cada um deles.

\footnotetext{
${ }^{348}$ CARVALHO, Paulo de Barros. Curso de direito tributário. op. cit, p. 294-295. O autor ainda demonstra que o mesmo equívoco é colhido nos artigos 23 e 46 do CTN, que tratam, respectivamente, dos "fatos geradores" (rectius: dos aspectos temporais das correspondentes hipóteses de incidência) do Imposto sobre Exportação (I.E.) e do Imposto sobre Produtos Industrializados (IPI),

${ }^{349}$ CARVALHO, Paulo de Barros. Curso de direito tributário. op. cit., p. 313-314.
} 


\subsubsection{ASPECTO PESSOAL}

O critério pessoal da regra-matriz de incidência tributária indica os sujeitos que ocuparão os polos ativo e passivo da relação jurídica que será instaurada com a ocorrência do fato descrito no antecedente daquela regra-matriz.

Sujeito ativo da obrigação tributária é a pessoa titular da capacidade para exigir o seu cumprimento. Pode ser o próprio ente instituidor do tributo, ou outro, ao qual seja delegada tal atribuição. A delegação do poder de exigir o tributo, denominada capacidade tributária ativa, pode ser a pessoa jurídica de direito público ou de direito privado ${ }^{350}$.

Nada obsta que seja atribuída capacidade tributária a ente distinto da União, criado para atender às finalidades estabelecidas pela lei, que instituiu as contribuições especiais. As contribuições especiais poderão ter cunho parafiscal, como é o clássico exemplo das contribuições de interesse de categorias profissionais. A União, detentora da competência tributária, cria e institui o tributo, mas transfere o poder de cobrar, a capacidade tributária ativa. A partir desse momento, o sujeito ativo da contribuição de interesse de categorias profissionais ou econômicas passa a ser a categoria profissional ou econômica, e não a União, que continua sendo detentora da competência legislativa plena. Todavia, a parafiscalidade não pode ser considerada uma característica de todas as contribuições especiais.

Já o sujeito passivo da relação jurídica tributária é a pessoa que tem o dever de cumprir a prestação que constitua o objeto da obrigação. O CTN distingue os sujeitos passivos da obrigação principal e da obrigação acessória.

Geraldo Ataliba afirma que o sujeito passivo, em regra, é uma pessoa que está em conexão íntima, relação de fato, com o núcleo, aspecto material, da hipótese de incidência. ${ }^{351}$

$\mathrm{O}$ art. 121 do CTN dispõe que o sujeito passivo da obrigação tributária principal "é a pessoa obrigada ao pagamento de tributo ou penalidade pecuniária", enquanto o art. 122 traz o sujeito passivo da obrigação acessória, "pessoa obrigada às

\footnotetext{
${ }^{350}$ Para o CTN, art. 119, somente podem ser sujeitos ativos de obrigação tributária as pessoas jurídicas de direito público. Tal ideia é confirmada pela leitura do art. $7 .^{\circ}$ do CTN, que, ao autorizar a delegação da capacidade tributária ativa, isto é, o poder de exigir o tributo, a terceiras pessoas, somente admite a delegação a pessoas jurídicas de direito público. Parte significativa da doutrina pátria, no entanto, critica tal disposição, pois entende que a delegação pode dar-se, de igual modo, a pessoas jurídicas de direito privado. Nesse sentido, ver: ATALIBA, Geraldo. Hipótese de incidência tributária. 6. ed. São Paulo: Malheiros, 2008, p. 189; CARVALHO, Paulo de Barros. Curso de direito tributário. 19. ed. São Paulo: Saraiva, 2007, p. 330-332; AMARO, Luciano. Direito tributário brasileiro. 16. ed. São Paulo: Saraiva, 2010, p. 320.

${ }^{351}$ ATALIBA, Geraldo. op. cit., p. 86.
} 
prestações que constituam o seu objeto". O objeto dessa obrigação é uma prestação positiva ou negativa não pecuniária, fazer ou deixar de fazer alguma coisa, que não seja dar dinheiro, nos termos do art. $113, \S 2 .^{\circ}{ }^{352}$

Especificamente no que diz respeito à tributação ambiental, em sentido lato, a identificação do sujeito passivo, em princípio, será dada por meio da aplicação do princípio do poluidor-pagador. A aplicação desse princípio, em matéria tributária, identifica como fato jurídico tributário a própria poluição ambiental ou o uso de recursos naturais. Sendo assim, o sujeito que gerar a poluição ou se utilizar dos bens naturais será considerado o sujeito passivo da obrigação. ${ }^{353}$

Cristóbal Borrero Moro assevera que, nos tributos que possuam em seu aspecto material atividades que ocasionem degradação do meio ambiente, o realizador da atividade degradante se converte no contribuinte, porque é quem realiza o elemento nuclear da hipótese de incidência. Essa configuração jurídica se mostra perfeitamente coerente com o princípio do poluidor-pagador, como critério de imputação de custos. Nesse caso, a atividade poluidora desenvolvida é imputável ao realizador da atividade, portanto, sobre esse sujeito deve recair o gravame. ${ }^{354}$

Segundo Cláudia Alexandra Soares, ao partir do conteúdo jurídico do princípio do poluidor-pagador, o ato contaminante deve ser o próprio fato gerador do imposto, para que, desse modo, se possa considerar como sujeito passivo aquele que perturbou o equilíbrio ecológico. Portando, seria o próprio agente contaminador, que praticou o ato causador da poluição, quem deveria assumir a qualidade de sujeito passivo. ${ }^{355}$

Para Jorge Jiménes Hernández, o estudo dos sujeitos passivos na tributação ambiental não deve partir da própria poluição, mas, sim, do que a lei dispõe e fixa como critério material da hipótese. Apesar da necessidade de o mencionado aspecto material ter alguma relação com alguma manifestação contaminante, o autor faz essa ponderação, para poder sustentar a veiculação das demais espécies tributárias como tributos ambientais, porque o mencionado aspecto material pode consistir em uma atividade poluidora, mas também um consumo ou uma atividade da administração, desde que tenham relação com alguma manifestação contaminante. ${ }^{356}$

\footnotetext{
${ }^{352}$ AMARO, Luciano. op. cit., p. 324.

353 AMARAL, Paulo Henrique. Op. cit., p. 214.

${ }^{354}$ MORO, José Borrero. La tributación ambiental en España. Madrid, Editorial Tecnos, S. A., 1999, p. 126.

355 SOARES, Cláudia Alexandra O imposto ecológico - contributo para o estudo dos instrumentos econômicos de defesa do ambiente. Coimbra, Coimbra, 2001, p. 495.

${ }^{356}$ HERNÁNDEZ, Jorge Jiménez. Op. cit., p. 172.
} 


\subsubsection{ASPECTO QUANTITATIVO: BASE DE CÁLCULO E ALÍQUOTA}

$\mathrm{O}$ aspecto quantitativo da regra-matriz de incidência tributária é composto por dois elementos: a base de cálculo e a alíquota.

Base de cálculo é a grandeza escolhida pelo legislador para dimensionar monetariamente o fato gerador do tributo e sobre a qual se aplica a alíquota, para a determinação do valor do tributo.

Hugo de Brito Machado assevera que a base de cálculo é a expressão econômica do fato gerador do tributo. Nesse contexto, quando a lei institui um tributo, necessariamente ela tem de referir-se a uma realidade economicamente quantificável, que permite ao intérprete identificar a espécie tributária. ${ }^{357}$

Alfredo Augusto Becker afirma que o critério objetivo e jurídico para a determinação da natureza jurídica do tributo é a base de cálculo e basta verificar a base de cálculo para que se confira, sempre e necessariamente, o gênero jurídico do tributo ${ }^{358}$.

Luís Eduardo Schoueri faz importante observação acerca da base de cálculo e afirma que, conquanto a base de cálculo não possa ser isolada da hipótese de incidência na definição da espécie tributária, serve para confirmar a ação do legislador ordinário, uma vez que nem toda base de cálculo serve para qualquer tributo. ${ }^{359}$

Alíquota, segundo Valdir de Oliveira Rocha, é o fator que se aplica à base de cálculo, para poder quantificar o montante do tributo. ${ }^{360}$

Hugo de Brito Machado afirma que a alíquota é a relação existente entre a expressão quantitativa ou dimensível, do fato gerador e o valor do tributo correspondente. $^{361}$

Importante destacar que são perfeitamente aceitáveis as alíquotas fixas, que permanecem inalteráveis, seja qual for a importância da base de cálculo. ${ }^{362}$

Feitas essas considerações, vejamos, agora, qual espécie tributária do sistema tributário nacional seria mais adequada para servir de veículo para um tributo ecológico.

${ }^{357}$ MACHADO, Hugo de Brito. Curso de direito tributário. $29^{\mathrm{a}}$ ed., São Paulo: Malheiros Editores, 2008, p. 135.

${ }^{358}$ BECKER, Alfredo Augusto. op. cit., p. 394.

${ }^{359}$ SCHOUERI, Luís Eduardo. Direito tributário. op. cit., p. 456.

${ }^{360}$ ROCHA, Valdir de Oliveira. Determinação do montante do tributo: quantificação, fixação e avaliação. 2. ed. São Paulo: Dialética, 1995, p. 119.

${ }^{361}$ MACHADO, Hugo de Brito. op. cit., p. 136.

${ }^{362}$ Ibidem, p. 173. 
Importante ressaltar que partimos da premissa de que tributo ecológico, nos termos adotados pela OCDE e pela Comissão Europeia, ${ }^{363}$ é o que tem, na sua base de cálculo, uma unidade física - ou um substituto próximo dessa - de alguma coisa que, quando usada ou lançada ao meio ambiente, tenha um comprovado e específico impacto negativo. Esse impacto negativo pode ser a deterioração de recursos ambientais até então gratuitos ou a redução da oferta de tais recursos. Aliada a esta premissa, levaremos em conta, também, a experiência estrangeira analisada.

Quando diferenciamos as espécies tributárias e especificamos as suas características, já descartamos, de plano, duas das espécies do sistema tributário nacional: as contribuições de melhorias e os empréstimos compulsórios.

De forma resumida, a contribuição de melhoria é incompatível com a ideia de se tributar uma substância poluidora, porque, para que se possa caracterizar um tributo como sendo dessa espécie, obrigatoriamente, requer-se uma obra pública e a valorização imobiliária em decorrência da obra estatal, ou seja, incompatíveis os aspectos materiais.

Em relação aos empréstimos compulsórios, nossa maior objeção é em relação à sua característica da excepcionalidade. Trata-se, pois, de um tributo excepcional, e, cessadas as causas que deram origem àquele empréstimo, eles deverão ser devolvidos. No entanto, no que diz respeito à sua materialidade, naquele período em que estiver sendo cobrado, se levarmos em consideração, apenas, a possibilidade de ele incidir sobre a poluição, tal espécie poderá ser entendida como adequada, embora tenha o defeito de simplesmente visar à obtenção de recursos para a consecução da circunstância excepcional que lhe deu origem.

Dessa forma, a questão concentra-se nos impostos, nas taxas e nas contribuições interventivas. Vejamos, primeiro, impostos e taxas, já que as contribuições não possuem a sua materialidade definida na Constituição.

Vimos que as taxas devem retribuir os gastos do Estado com um serviço público, prestado ou posto à disposição, de forma específica e divisível, ou em razão do poder de polícia do ente competente.

Existem, na experiência comparada, alguns serviços que são cobrados com base na quantidade de material a ser recolhido ou limpo e, ainda, com diferenciações referentes à espécie do material, ou grau de contaminação ou periculosidade. Essa espécie de taxa, de fato, leva em consideração, na hora de estipular a base de cálculo, a

${ }^{363}$ EUROPEAN COMMISSION. Manual: Statistics on Environmental Taxes. Version 3.0., 28.7.1996, p. 3. 
periculosidade ou contaminação do material e, nesse sentido, é uma taxa ambientalmente orientada, já que atribui critérios ambientais em sua hipótese normativa.

No entanto, o fato de o ente estatal cobrar um serviço público de forma ambientalmente diferenciada, demonstra-nos, apenas, que os custos do serviço público são diferentes para que o mesmo serviço seja feito em um bem não perigoso e em outro perigoso. Como vimos, é certo que todo e qualquer tributo causa, em maior ou menor grau, um efeito fiscal e outro extrafiscal. O efeito caro parece-nos, de forma clara, que pode até existir algum efeito indutor, mas será pequeno e secundário. Portanto, como instrumento que vise a proteger o meio ambiente e a ter, como efeito primário, a indução comportamental, as taxas de serviço público não são as mais adequadas.

As taxas referentes ao poder de polícia do Estado parecem-nos trilhar o mesmo caminho, visto que, na fiscalização, o Estado só irá verificar se o indivíduo agiu ou está em conformidade com a legislação. $\mathrm{O}$ indivíduo pede para ser fiscalizado, com o intuito de obter alguma espécie de autorização, em sentido amplo, para poder exercer alguma atividade. A taxa cobrada é em razão do custo daquela fiscalização.

Do mesmo modo, na taxa de serviço público, pode existir diferenciação dos valores cobrados, tendo em vista os custos que tais fiscalizações geram. Por exemplo, o custo de fiscalização de duas empresas do setor energético poderá ser diferente, porque, para que o fiscal exerça suas atividades em uma empresa que gera energia a partir da fusão de partículas atômicas - energia nuclear, portanto o custo dessa fiscalização é muito maior do que em comparação à fiscalização de uma empresa, que gera energia por meio de painéis fotovoltaicos, energia solar.

Portanto, por si só, a taxa não tem o poder de induzir comportamentos, não é ela que muda o comportamento, uma vez que o Estado, ao fiscalizar, apenas irá verificar a conformidade legal daquela atividade. E, caso o indivíduo não esteja em conformidade com a lei, ele não será tributado por tal atitude, mas, sim, punido. Desse modo, como a taxa não tem o poder de induzir comportamentos, não vislumbramos esta espécie como adequada para tributação ecológica.

Com base na análise feita da experiência dos países estrangeiros e da própria definição da qual partimos, de tributo ecológico, enxergamos o imposto como veículo adequado para criação de um tributo ecológico, em razão de não ter sua materialidade vinculada a nenhuma atividade estatal e de ser um forte instrumento de indução comportamental. 
No entanto, como o Constituinte dividiu de maneira rígida e taxativa toda competência ambiental, podemos afirmar que, da forma como o sistema está posto, apenas a União, por meio da sua competência residual, tem como instituir impostos, sem que haja mudança constitucional.

Nesse contexto, as CIDEs, igualmente, apresentam-se como veículo viável e eficaz, para criação e instituição de um tributo que tenha no seu aspecto material algum tipo de poluição.

A contribuição interventiva mostra-se um veículo adequado em razão de não ter sua materialidade delimitada na Constituição e, assim, o legislador pode escolher qualquer fato que entenda como adequado, desde que ele tenha uma relação com a intervenção e com o grupo econômico no qual ela foi instituída.

Em nosso entendimento, a contribuição ainda possui algumas vantagens sobre os impostos. A contribuição interventiva, obrigatoriamente, deve ser instituída sobre um grupo determinado, um setor específico do domínio econômico, e a sua receita deve ser vinculada a uma finalidade predeterminada e, como já integra o sistema, não é necessária nenhuma alteração constitucional.

Dessa forma, a União poderá instituir um tributo sobre a emissão de algum agente poluidor, já que não possui sua materialidade vinculada pelo texto constitucional; terá a vantagem de escolher o setor do domínio econômico que apresenta maiores índices de poluição, visto que essa espécie deve incidir sobre um setor específico do domínio econômico; o critério de discriminação, defesa do meio ambiente, "mediante tratamento diferenciado conforme o impacto ambiental dos produtos e serviços e de seus processos de elaboração e prestação", é, na verdade, um dos mandamentos constitucionais, elencados como princípio da ordem econômica; paralelamente, ainda, há a vantagem de ter a sua receita vinculada a finalidade predeterminada, que, em razão da experiência estrangeira, deveria ser o subsídio das contribuições sociais, porque a análise comparada mostrou que a redução da carga tributária incidente sobre o trabalho é um estímulo a contratações, faz com que se obtenha aumento no grau de eficiência e gere, assim, o duplo benefício. 


\section{CONCLUSÃO}

O objetivo deste estudo consistia na análise da compatibilidade de um tributo ambiental com o sistema tributário nacional. Partindo da premissa de que o tributo ambiental incide sobre a própria emissão da poluição, passamos a denominá-lo de tributo ecológico, a fim de evitar maiores conflitos com o tributo apenas ambientalmente orientado, isto é, o que incide sobre algum fato ordinário, mas orienta os seus valores, em razão do maior ou menor impacto sobre o meio ambiente. A análise da compatibilidade anteriormente referida foi dividida em duas vertentes: uma análise teórica, isto é, se o sistema jurídico permitiria tal imposição, e uma análise pragmática, isto é, se seria praticável um tributo nesses termos, da forma como o sistema está posto e funciona.

Para a consecução desse fim, analisou-se primeiramente as questões referentes à indução comportamental por meio da tributação, relacionando-a com o desenvolvimento nacional, as externalidades negativas e a proteção do meio ambiente. Posteriormente, investigamos a interação sistêmica entre as ordens econômica e tributária e a defesa do meio ambiente por meio de alguns princípios que entendemos serem os mais relevantes para os fins deste estudo. Em seguida, discorremos sobre a distribuição e interação das competências ambientais e tributárias. No terceiro momento, foi analisada a experiência estrangeira na defesa do meio ambiente, por meio do uso da tributação. Diante dessa análise, testamos as espécies tributárias existentes em nosso sistema a fim de verificar qual espécie, ou espécies, seria mais adequada para servir como veículo para um tributo ecológico em nosso sistema.

Feitas tais considerações e após as investigações teóricas realizadas, chegamos às seguintes conclusões:

A intervenção do Estado sobre o domínio econômico já não pode mais ser considerada eventual ou esporádica. Se essa intervenção antes era vista como algo a ser combatido e repelido, em prol da total liberdade dos indivíduos e do próprio mercado, atualmente, o próprio mercado e os agentes econômicos clamam pela intervenção estatal, a fim de garantir um ambiente econômico concorrencial saudável e seguro, principalmente contra crises econômicas.

Não há mais espaço para querer entender a neutralidade tributária como sinônimo de absenteísmo estatal, tampouco querer defender que o tributo não tenha efeitos 
sobre as decisões de mercado. Atualmente, tem-se como certa a ideia de que o tributo é, por sua natureza, um instrumento de interferência nas decisões mercadológicas, tanto dos agentes de mercado, quanto dos consumidores.

Consciente de que o tributo exerce influência sobre os comportamentos dos consumidores e, por consequência, dos agentes econômicos, o Estado possui um forte instrumento de intervenção na economia e na sociedade porque, ao intervir na economia, o Estado pode sinalizar os caminhos e comportamentos que entende como os mais adequados, em conformidade com as suas políticas públicas, os preceitos e objetivos inseridos na Constituição.

A ideia de se utilizar o tributo como instrumento de intervenção na economia não pode ser confundida com a ideia de se tributar os atos ilícitos, visto que tributo decorre de ato lícito, sanção de ato ilícito. Dessa forma, não há que se falar em tributar determinada atividade, tão logo ela supere os limites impostos pela legislação, porque, a partir do momento em que a ação deixou de ser lícita, deixa de ser tributo e passa a ser alvo de possível sanção.

$\mathrm{O}$ meio ambiente natural ou ecológico está diretamente vinculado à sadia qualidade de vida, logo é direito fundamental garantido por nossa Constituição Federal, em seu art. 225, embora, ao mesmo tempo, o ambiente natural seja uma das bases da economia. O ambiente natural ou ecológico, entendido como fonte primária de matériaprima, ao se alinhar com o trabalho e o capital, formam as bases do tripé econômico.

O desenvolvimento nacional é um dos objetivos fundamentais da República Federativa do Brasil. Numa análise mais superficial, poder-se-ia dizer, então, que o desenvolvimento nacional conflitaria, diretamente, com a preservação do meio ambiente ecologicamente equilibrado. Tal assertiva não é verdadeira por si só, visto que o desenvolvimento nacional não pode ser entendido como a simples geração de riquezas, entendimento já superado e que constituía o pensamento predominante até meados do século passado; não subsiste mais como pensamento moderno.

O desenvolvimento nacional pressupõe o desenvolvimento da própria sociedade: trata-se da evolução humana, não associada de algumas ideias básicas de liberdade, como acesso à educação, à saúde, a um ambiente sadio e ecologicamente equilibrado, entre outros. O simples crescimento econômico não traz esses benefícios, ao contrário, afasta-os em razão do aumento das desigualdades sociais. O desenvolvimento econômico pode e deve ser um passo para se alcançar o desenvolvimento nacional, mas não pode ser entendido como fim em si mesmo. Sendo assim, índices de desenvolvimento 
que levem em consideração apenas o crescimento da produção de riqueza de um Estado estão em reformulação, com o intuito de se inserirem novos parâmetros sociais.

O mercado foi entendido, durante algum tempo, como autorregulável e autossuficiente. Vindas inúmeras crises e o surgimento de grandes distorções mercadológicas, deixaram-se de lado as ideias de autorregularidade e autossuficiência, para assumir a dependência do mercado perante o Estado, com o intuito de que esse regulamente o mercado e garanta ao máximo as condições da livre iniciativa e livre concorrência.

Assumida a dependência do mercado com o Estado, surgem estudos que demonstram as principais falhas do mercado e afirmam competir àquele tentar solucionálas. São elas: a) mobilidade de fatores; b) acesso às informações relevantes; $c$ ) concentração econômica; $d$ ) bens públicos; e $e$ ) externalidades. No tocante à defesa do meio ambiente, as externalidades são as que têm merecido mais atenção.

Externalidade é o custo ou o benefício, gerado por um indivíduo, mas transferido para outro indivíduo, sem tipo algum de compensação ou pagamento. Chamase de externalidade negativa a transferência dos custos gerados por um indivíduo, mas transferido para o outro, sem que haja algum tipo de compensação. Um exemplo muito comum de externalidade negativa é, precisamente, a poluição gerada por um indivíduo, mas transferida para a sociedade, do mesmo modo que, quando uma indústria não possui filtros adequados e expele fumaça tóxica, é a sociedade daquela região que arcará com os custos, saúde, limpeza, entre outros, causados pela fumaça gerada por aquela indústria.

Arthur C. Pigou, grande economista inglês, propusera, em 1920, que, para se internalizar as externalidades, se deveria tributar as negativas e subsidiar as positivas. Essa ideia ficou conhecida como "imposto-pigou" ou "imposto pigouviano" e continua sendo a base mestra para a tributação ambiental até hoje.

A correção das falhas de mercado, especialmente em relação às externalidades, pode acarretar um duplo dividendo, isto é, com apenas uma ação, a imposição tributária, corrige-se a falha pretendida, pois ela foi economicamente desestimulada. Com essa mesma ação, obtêm-se recursos, que podem ser investidos em outras áreas, como para melhorar a eficiência do próprio sistema tributário.

Mas, como toda ação humana gera algum tipo de resíduo, que pode ser entendido como poluição e, da mesma forma, pode ocorrer com as atividades econômicas, torna-se impossível, praticamente, extinguir ou proibir toda e qualquer forma de poluição, 
de geração de resíduos, além de ser extremamente difícil conseguir calcular um valor fixo do custo daquela externalidade.

A nossa Constituição impõe ao Poder Público - termo que nos remete ao sentido mais amplo possível de Estado -, assim como à coletividade, ou seja, à própria sociedade, o dever de defesa do ambiente ecologicamente equilibrado.

Para dar concreção a esse dever, o Estado tem à sua disposição instrumentos de comando e controle: os clássicos instrumentos de regulação e proibição de determinadas atividades ou limites a essas atividades e, modernamente, os instrumentos de mercado, nos quais os tributos ecológicos se inserem.

A noção de sistema jurídico implica as ideias de ordem e unidade. Dessa forma, tratando-se de unidade, o sistema deve ser interpretado no seu todo e não em partes. Do sistema maior, que é a Constituição, podemos extrair verdadeiros subsistemas, como o da ordem econômica e tributária e as normas que cuidam da matéria ambiental. Mas esses subsistemas servem, apenas, para identificar princípios autônomos e facilitar o estudo autônomo das respectivas matérias, uma vez que, quando o intérprete estiver diante de um caso concreto, obrigatoriamente, ele terá de percorrer todo o sistema.

Assim, a análise da possibilidade de um tributo ecológico deve passar pelo crivo de todo o sistema constitucional, notadamente do subsistema tributário, do subsistema econômico e do subsistema que cuida do meio ambiente.

Quando se fala de tributo, necessariamente, há que investigar se tal tributo obedece aos princípios e regras do subsistema tributário, visto que, independentemente de o tributo ser fiscal ou extrafiscal, por ser norma tributária, deve obediência aos princípios e regras tributárias, em especial, aos princípios da legalidade e da igualdade.

O princípio da legalidade representa verdadeiro limite ao Poder do Estado, porque ele prevê que o próprio povo, verdadeiro detentor do poder estatal, é quem irá decidir, em última análise, se concorda ou não com o aumento ou a nova imposição tributária, além de trazer consigo a ideia de certeza, uma vez que todos os elementos que devem compor o tributo e, dessa maneira, formar a hipótese tributária, deverão estar previstos em lei.

A igualdade decorre da própria ideia de Estado de Direito e, portanto, deve ser obedecida sempre. Ocorre que igualdade não é identidade e, dessa forma, o legislador pode adotar critérios de discriminação, desde que sejam constitucionalmente válidos.

A capacidade contributiva é corolário da igualdade, porque remete à ideia de que os indivíduos arquem com as despesas do Estado com base no seu potencial 
econômico: quem possui mais riqueza arca com uma parte maior; quem possui menos riqueza paga uma parcela menor. Esse princípio tem especial contorno em relação aos impostos e, quanto a todas as outras espécies tributárias, deve ser obedecido o comando constitucional do não confisco, ou seja, não existe a possibilidade de se instituir um tributo que gere o efeito de confisco, ou sufoque a atividade econômica. Se a atividade for indesejada em um grau tão elevado, que se queira impor um tributo sufocante, o certo é proibir tal atividade, mas não tentar tributar até o ponto de inviabilizar a atividade econômica.

Em relação à tributação extrafiscal, o princípio da igualdade pode ser mitigado, mas não abandonado. Desse modo, é necessário que o legislador ordinário adote algum critério constitucionalmente válido para efetivar a discriminação e não pode, igualmente, se desviar das bases econômicas quando for instituir um tributo extrafiscal. Ainda assim, terá de observar, no mínimo, alguma situação que, ao menos, reflita uma situação econômica geradora de riqueza.

A livre concorrência, em última análise, também decorre da igualdade, visto que prescreve a liberdade de todos concorrerem num mercado aberto a eles, sob as mesmas condições e oportunidades. Dessa forma, a tributação não pode chegar ao ponto de afetar essa concorrência, ou seja, em razão da unidade sistêmica, os tributos também devem obediência ao princípio da livre concorrência, já que um tributo não pode impedir que os agentes de um mesmo setor atuem sob as mesmas condições. Do ponto de vista do comércio internacional, a tributação interna, igualmente, não pode ser um empecilho para as exportações e, em decorrência, o tributo interno não deve fazer com que o bem já saia do território nacional em situação desfavorável econômica e concorrencialmente.

A defesa do meio ambiente é um dever de todos, mas ganhou destaque no conjunto de princípios que regem a ordem econômica, no art. 170 da CF/88. Isso significa que as ações adotadas pelo Estado, em prol da ordem econômica, deverão, igualmente com os outros princípios, almejar a proteção do meio ambiente, inclusive mediante tratamento diferenciado conforme o impacto ambiental dos produtos e serviços e de seus processos de elaboração e prestação.

Em nosso entendimento, esse dispositivo não traz qualquer nova competência tributária. No entanto, pode e deve ser utilizado como critério de discrímen, na modificação, majoração ou, até mesmo, na introdução de um novo tributo. 
Todas as competências tributárias estão expressamente previstas na Constituição Federal. Adotamos a corrente que entende que a Constituição prevê cinco espécies: impostos, taxas e contribuições de melhoria, de competência comum dos três entes federativos, mais o Distrito Federal, além das contribuições especiais e dos empréstimos compulsórios, de competência exclusiva da União.

Em relação aos impostos, todos os que são possíveis de serem instituídos e cobrados em nosso ordenamento já estão igualmente previstos na Constituição e com a sua devida repartição de competência. A Constituição diz qual ente vai poder instituir e cobrar qual imposto, de forma taxativa. Em relação à União, outorgou a essa a competência residual, isto é, a possibilidade de criar novos impostos, desde que já não estejam previstos no próprio Texto Constitucional - isto é, que o novo imposto tenha hipótese tributária ou base de cálculo própria de algum imposto já descrito pela Constituição - e, ainda, que seja não cumulativo e criado por meio de lei complementar (art. 152, CF/88).

A repartição de competência em matéria ambiental é bastante complexa, porque a Constituição outorga competência exclusiva à União em poucas matérias, tais como elaborar e executar planos nacionais e regionais, legislar sobre águas e recursos nucleares. A competência material comum é outorgada a todos os entes da Federação, ou seja, em consonância com o art. 225, estabelece que é dever de todos, inclusive do Poder Público, aqui inseridos todos os entes federativos, proteger o meio ambiente. Ainda prevê a competência legislativa concorrente entre Estados, Distrito Federal e União, para legislar sobre algumas matérias, tais como controle da poluição, proteção do meio ambiente e defesa dos recursos naturais, entre outros. Em resumo, podemos afirmar que, em matéria de defesa do meio ambiente, todos os entes federativos podem exercê-la, isto é, são competentes, materialmente, para defendê-lo.

Essa análise da divisão de competências é importante porque entendemos que a criação de um tributo ecológico requer dupla competência - tributária e ambiental. Nesse sentido, no nosso sistema, a criação de um tributo ecológico depende muito mais da competência tributária propriamente dita, do que da competência ambiental, uma vez que, em pouquíssimas matérias, a União detém competência exclusiva, já que o normal é a competência comum.

Analisados alguns países que usam o tributo como instrumento de defesa do meio ambiente, pudemos constatar que inúmeros deles já realizaram, ou ainda está em curso alguma espécie de reforma fiscal ecológica, isto é, os países estão reformulando os seus sistemas tributários para modificar as tradicionais bases de arrecadação sobre o 
patrimônio, a renda ou o consumo, com o intuito de tributar ações ou fatos que gerem poluição, sejam ecologicamente degradantes ou mesmo reflitam um novo ângulo sobre o valor dos bens naturais, como é o caso da tributação holandesa sobre a extração de águas subterrâneas.

Importante ressaltar que, em todos os países, estudos se preocuparam com a possível perda de competitividade internacional de suas empresas, de forma que a maioria deles resolveu esse problema vinculando o produto da arrecadação do novo tributo para subsidiar os tributos incidentes sobre o trabalho, especialmente as contribuições sociais dos trabalhos, responsável por gerar ganho de eficiência e competitividade.

Também houve problemas, normalmente naqueles países que possuem uma forma de Estado mais descentralizada, relativos à invasão de competência tributária do ente que estava instituindo um tributo sob o argumento ambiental, embora, na verdade, a base incida sobre outra riqueza que já era tributada. Também surgiram problemas referentes à igualdade, quando apenas um setor possuía incentivos fiscais, enquanto todos os outros eram tributados. Os incentivos fiscais eram justificados sob o argumento de que aquele setor específico concorria internacionalmente e os outros, não, e, assim, estaria justificada a discriminação, porém alguns dos agentes dos setores tributados também concorriam no mercado internacional.

Diante das experiências estrangeiras e das peculiaridades do nosso sistema, entendemos que as espécies mais adequadas para a tributação ecológica seriam os impostos e as contribuições interventivas, uma vez que são tributos não vinculados a uma atividade estatal, cujos aspectos materiais podem ser mais amplos e alcançar, assim, a própria poluição, como emissão de gases que causam o efeito estufa.

Como os impostos já estão exaustivamente previstos na Constituição Federal, no atual desenho constitucional, nenhum ente poderia criar tal tributo, com exceção da União, por meio da sua competência residual, obedecidos os requisitos constitucionais.

As CIDEs, por sua vez, apresentam uma forte aptidão para se tornarem um veículo do tributo ecológico, porque teriam a vantagem de incidir sobre um setor específico do domínio econômico, a defesa do meio ambiente mediante tratamento diferenciado ser um princípio constitucional da ordem econômica, legítima a imposição, e pela necessidade de sua receita ser vinculada a finalidade pré-determinada, poderia ser usada para subsidiar o pagamento das contribuições sociais, de modo a desonerar a carga fiscal sobre o trabalho e evitar, assim, a perda de competitividade e gerar o duplo dividendo, com aumento da eficiência. 
Assim, entendemos o tributo ecológico como compatível, teoricamente, com o sistema tributário nacional.

No entanto, apesar de aceitarmos a compatibilidade teórica, pragmaticamente, em razão do excesso de complexidade do nosso sistema, basta lembrar a quantidade de horas que os empresários brasileiros gastam a mais para quitar as suas obrigações fiscais, em comparação com os vizinhos da América Latina e com os países-membros da OCDE. A criação de mais um tributo complexo e de difícil administração, traria consigo o surgimento de mais obrigações acessórias, o que aumentaria ainda mais a quantidade de horas gastas para que os empresários cumprissem suas obrigações. Desse modo, um tributo como o estudado, da forma como o ordenamento está posto, só iria trazer ineficiência ao sistema, portanto, inviável, do ponto de vista prático.

Um tributo ecológico, como pudemos constatar, é altamente complexo, porque os cálculos necessários para se estipular os valores a serem cobrados envolvem uma série de variáveis. A fiscalização do tributo também é complexa e, dependendo do tipo de poluição, precisa de pessoal altamente qualificado, o que faz com que os custos da própria administração tributária aumentem.

Essa inviabilidade se traduz, ainda e principalmente, em função da nossa conturbada legislação tributária e do excesso de obrigações acessórias. É certo que a matéria tributária e a fiscalização tributária não são, por natureza, excessivamente simples, mas é certo, também, que o nosso sistema poderia ser mais simples. Dessa maneira, em razão da complexidade que se exige para criação, instituição e cobrança de um tributo ecológico, entendemos que, enquanto não vier uma reforma tributária para simplificar o sistema tributário nacional, a criação de mais um tributo complexo seria impraticável e inviável. 


\section{REFERÊNCIAS BIBLIOGRÁFICAS}

ADELMAN, Irma. Teorias do desenvolvimento econômico. Tradução de Denise Cabral C. de Oliveira. Rio de Janeiro: Forense, 1972.

ALEXY, Robert. Teoria dos direitos fundamentais, tradução de Virgilio Afonso da Silva, São Paulo, Malheiros Editores, 2008.

ALABERN, Juan Enrique Varona. Extrafiscalidad y dogmática tributária. Madrid, Marcial Pons, 2009.

ALTAMIRO, Alejandro C. Derecho tributario teoría general. Marcial Pons. Madrid, 2012.

AMARAL, Paulo Henrique. Direito tributário ambiental. São Paulo, Editora Revista dos Tribunais, 2007.

AMARO, Luciano. Direito tributário brasileiro. São Paulo, Editora Saraiva, 2010.

ANDRADE, José Maria Arruda de. Interpretação da norma tributária. São Paulo: MP Ed., 2006.

ANDRADE, Paulo Roberto. Tributação de atos ilícitos e inválidos. São Paulo, Quartier Latin, 2008.

ANTUNES, Paulo de Bessa. Direito ambiental. $5^{\text {a }}$ ed., Rio de Janeiro: Lúmen Juris, 2001.

ARAGÃO, Alexandra. Direito constitucional do ambiente da União Europeia. In: Direito constitucional ambiental brasileiro. José Joaquim Gomes Canotilho e José Rubens Morato Leite (org.). $3^{\text {a }}$ ed., São Paulo: Saraiva, 2010, p. 32 -76.

ATALIBA, Geraldo. Hipótese de incidência tributária. $6^{\mathrm{a}}$ ed., São Paulo: Malheiros Editores, 2008.

ÁVILA, Humberto. Sistema constitucional tributário. $4^{\mathrm{a}}$ ed., São Paulo, Saraiva, 2010.

. Teoria da igualdade tributária. 2a ed., São Paulo, Malheiros Editores, 2009.

Teoria dos princípios, da definição à aplicação dos princípios jurídicos. $8^{\mathrm{a}}$ ed., São Paulo, Malheiros Editores, 2008.

BALEEIRO, Aliomar. Direito tributário brasileiro. $11^{\mathrm{a}} \mathrm{ed}$., atualizada por Misabel Abreu Machado Derzi, Rio de Janeiro, Forense, 2009.

. Limitações constitucionais ao poder de tributar. $7^{\mathrm{a}}$ ed., atualizada por Misabel Abreu Machado Derzi, Rio de Janeiro, Forense, 2006. 
. Uma introdução à Ciência das Finanças. $18^{\mathrm{a}}$ ed., atualizada por Hugo de Brito Machado Segundo. Rio de Janeiro: Forense, 2012.

BARBOSA HEMPEL, Wilca. ICMS ecológico. Fortaleza: Edições Demócrito Rocha, 2007.

BARDE, Philippe. Green tax reforms in OECD countries: an overview. In II Taller Regional de Política Fiscal y Medio Ambiente en America Latina y el Caribe, Santigago de Chile, 27 de enero de 2004. www.oecd.org/env/taxes, acessado em 25.09.2012.

BARRETO, Paulo Ayres. Contribuições: regime jurídico, destinação e controle. São Paulo: Noeses, 2006.

BARROSO, Luís Roberto. Curso de direito constitucional contemporâneo: os conceitos fundamentais e a construção do novo modelo. $2^{\mathrm{a}}$ ed., São Paulo, Saraiva, 2010.

_. Interpretação e aplicação da Constituição: fundamentos de uma dogmática constitucional transformadora. $7^{\text {a }}$ ed., São Paulo, Saraiva, 2009.

BECKER, Alfredo Augusto. Teoria geral do direito tributário. $4^{\mathrm{a}}$ ed., São Paulo: Noeses, 2007.

BENJAMIN, Antônio Herman. "Constitucionalização do ambiente e ecologização da Constituição Brasileira”, in Direito Constitucional Ambiental Brasileiro, José Joaquim Gomes Canotilho, José Rubens Morato Leite (org.), $3^{\text {a }}$ ed., São Paulo: Saraiva, 2010, pág. $77-148$.

BERCOVICI, Gilberto. Constituição econômica e desenvolvimento, uma leitura a partir da Constituição de 1988. São Paulo: Malheiros Editores, 2005.

. "Constituição econômica e desenvolvimento", in Revista da Academia Brasileira de Direito Constitucional, v. 5, Curitiba: 2004.

BOBBIO, Noberto. Da estrutura à função: novos estudos de teoria do direito. Tradução de Daniela Beccaccia Versiani; revisão técnica de Orlando Seixas Bechara, Renata Nagamine. Barueri, SP: Manole, 2007.

BOMFIM, Diego. Tributação e livre concorrência. São Paulo: Saraiva, 2011.

BONAVIDES, Paulo. Curso de direito constitucional. $24^{\text {a }}$ ed., São Paulo, Malheiros Editores, 2009.

. Do estado liberal ao estado social. 9a ed., São Paulo, Malheiros Editores, 2009.

BORGES, Souto Maior. Obrigação tributária (uma introdução metodológica). $2^{\mathrm{a}}$ edição, São Paulo, Malheiros Editores, 1999. 
BOTALLO, Eduardo Domingos; CARRAZZA, Roque Antonio. "IPI, seletividade e alteração de alíquotas", in Revista Dialética de Direito Tributário, n. 159: São Paulo, 2008, pág. $107-114$.

CAMPOS, Diogo Leite e CAMPOS, Mônica Horta Neves Leite de. Direito tributário. Coimbra, Almedina, 2000.

CANARIS, Claus - Wilhelm. Pensamento sistemático e conceito de sistema na ciência do direito. Traduzido do original alemão intitulado: Systemdeken und Systembegriff in der Jurisprudenz, 2. Auflage, 1983, por António Manuel da Rocha e Menezes Cordeiro, Lisboa: Fundação Calouste Gulbenkian, 1989.

CANOTILHO, José Joaquim Gomes. MORATO, José Rubens. Direito constitucional ambiental brasileiro. $3^{\mathrm{a}}$ ed., São Paulo, Saraiva, 201, vários autores.

. Estudos sobre direitos fundamentais. São Paulo, em co-edição Editora Revista dos Tribunais e Coimbra Editora, 2008.

CAPANO, Rafaele Perrone. La imposición y el ambiente. In Tratado de Derecho Tributario, tomo primero El Derecho Tributario e Sus Fuentes. AMATUCCI, Andrea (coord.). Editorial Temis S.A.: Bogotá-Colombia, 2001, 421 - 540.

CARNEIRO, Ricardo. Direito ambiental: uma abordagem econômica. Rio de Janeiro, Forense, 2001.

CARRAZZA, Roque Antonio. Curso de direito constitucional tributário. 23a ed., São Paulo, Malheiros Editores, 2007.

CARVALHO, Paulo de Barros. Curso de direito tributário. $19^{\mathrm{a}}$ ed., São Paulo, Saraiva, 2007.

Direito tributário: fundamentos jurídicos da incidência. $7^{\mathrm{a}}$ ed., São Paulo, Saraiva, 2009.

. Teoria da norma tributária. 3. ed. São Paulo: Max Limonad, 1998.

CARVALHOSA, Modesto. Direito econômico: obras completas. São Paulo: Editora Revista dos Tribunais, 2013.

CIANCIARDO, Juan. "Princípios e regras: uma Abordagem a partir dos Critérios de Distinção", tradução de Edson Bini, in Princípios e Limites da Tributação. FERRAZ, Roberto Catalano Botelho (coord.). São Paulo: Quartier Latin, 2005, pág. 105 - 118.

CHRISTENSEN, Hans. Danish experience with waste charges. In: Papers frorm Dublin Workshop, Environmental Taxes \& Charges, National Experiences \& Plans, European Foundation, 1996, p. 1- 14. 
COÊLHO, Sacha Calmon Navarro. Curso de direito tributário brasileiro. Rio de Janeiro: Forense, 2009.

CORRÊA, Walter Barbosa. Contribuição ao estudo da extrafiscalidade. São Paulo: Bentivegna, 1964.

CORREIA NETO, Celso de Barros. "Instrumentos fiscais de proteção ambiental", in Revista Direito Tributário Atual, v. 22. São Paulo, Dialética e IBDT - Instituto Brasileiro de Direito Tributário, 2008, pp. 140 - 160.

COSTA, Carla guapo. A matriz energética da União Europeia e o caso particular dos biocombustíveis: diagnóstico e perspectivas. In: Oficinas do CETEM - Centro de tecnologia mineral. Rio de Janeiro, 2010. Disponível em: http://www.cetem.gov.br/agrominerais/documentos/oficina5/Apresentacao04.pdf acessado em 10.12.2013.

COSTA, Ramón Valdés. Curso de Derecho Tributario. $4^{\mathrm{a}}$ ed., Montivideo - Buenos Aires, Editorial IB de F, 2013.

COSTA, Regina Helena. Princípio da capacidade contributiva. $2^{\mathrm{a}}$ edição. São Paulo. Malheiros Editores, 1996.

- Praticabilidade e justiça tributária, exequibilidade de lei tributária e direitos do contribuinte. São Paulo: Malheiros Editores, 2007.

. Curso de direito tributário: Constituição e Código Tributário Nacional. $2^{\mathrm{a}}$ ed., São Paulo: Saraiva, 2012.

DANTAS, Marcelo Barreto. As contribuições de intervenção no domínio econômico em face da Emenda Constitucional n. 42/03. In: MOREIRA FILHO, Aristóteles; LÔBO, Marcelo Jatobá (coord.). Questões controvertidas em matéria tributária: uma homenagem ao professor Paulo de Barros Carvalho. Belo Horizonte: Fórum, 2004.

DEJALMA de. Dimensão jurídica do tributo. In: TAVOLARO, Agostinho Toffoli et. al. (coord.). Princípios tributários no direito brasileiro e comparado: estudos em homenagem a Gilberto de Ulhôa Canto. Rio de Janeiro: Forense, 1988.

DEODATO, Alberto. As funções extra-fiscais do imposto. Tese apresentada à Faculdade de Direito da Universidade de Minas Gerais para o concurso de Professor Catedrático de Ciência das Finanças, 1949.

DERANI, Cristiane. Direito ambiental econômico. $3^{\text {a }}$ ed., São Paulo: Saraiva, 2008.

DERZI, Misabel. Direito tributário, direito penal e tipo. $2^{\text {a }}$ ed., São Paulo: Editora -Revista dos Tribunais, 2007. 
Doing Business, 2012. Copublication of The World Bank and The International Finance Corporation.

DUVERGER, Maurice. Hacienda pública. Traducción de Enrique Bagaria Perpiná. $2^{\mathrm{a}}$ ed., Barcelona: BOSCH, Casa Editorial S.A., 1980.

DWORKIN, Ronald. Taking rights seriously. Cambridge - Massachusetts, Harvard University Press, 1978.

ENGISCH, Karl. Introdução ao pensamento jurídico. Tradução de J. Baptista Machado, 10ª ed., Lisboa, Fundação Calouste Gulbenkian, 2008.

ESTRADA, Iñaki Bilbao. "El gravamen de lãs emisiones atmosféricas en la Unión Europea (EU) y la lucha contra el cambio climático: Uma reflexión sobre la necessidad de coordinación entre instrumentos econômicos", in XXV Jornadas Larinoamericanas y XXXIV Colombianas de Derecho Tributario: Foros e Debates, Cartagena de Indias, Colombia, 14-19 de febrero de 2010, pp. 45-76.

EUROPEAN COMMISSION. Manual: Statistics on Environmental Taxes. Version 3.0., 28.07.1996.

GAMA, Tácio Lacerda. Contribuição de intervenção no domínio econômico. São Paulo: Quartier Latin, 2003.

GIARDINA, Emilio. Le basi teoriche del principio della capacità contributiva. Milano: Giuffrè, 1961.

GODOI, Marciano Seabra de. "Tributo e solidariedade social”, in Solidariedade Social e Tributação. GRECO, Marco Aurélio; GODOI, Marciano Seabra de. (Coord.). São Paulo: Dialética, 2005, pág. 141 - 167.

GONZÁLEZ, Luis Manuel Alonso. Los impuestos ambientais em España: doctrina del Tribunal Constitucional. In: TÔRRES, Heleno Taveira (org.). Direito tributário ambiental. São Paulo, Malheiros Editores, 2005, p. 387 - 411.

FAJARDO, Juan Pablo Godoy. “Tributos e instrumentos económicos ambientales”, in XXV Jornadas Larinoamericanas y XXXIV Colombianas de Derecho Tributario: Foros e Debates, Cartagena de Indias, Colombia, 14-19 de febrero de 2010, pp. 115-135.

FALCÃO, Amilcar de Araújo. Fato gerador da obrigação tributária. Rio de Janeiro, Edições Financeiras S.A., 1964.

FALCÃO, Raimundo Bezerra. Direito econômico (teoria fundamental). São Paulo: Malheiros Editores Ltda., 2013. . Tributação e mudança social. Rio de Janeiro: Ed. Forense, 1981. 
FANUCCHI, Fábio. Curso de direito tributário brasileiro. v. 1. São Paulo: Resenha Tributária, 1971.

FERRARA, Franco Batistoni. I tributi ambientali nell'ordinamento italiano. In: SCAFF, Fernando FAcury; ATHIAS, Jorge Ales (coord.). Direito Tributário e Econômico aplicado ao Meio Ambiente e à Mineração. São Paulo: Quartier Latin, 2009, pág. 73 - 78.

FERRAZ, Roberto. "Igualdade na Tributação - Qual o Critério que Legitima Discriminação em Matéria Fiscal?", in Princípios e Limites da Tributação. FERRAZ, Roberto Catalano Botelho (coord.). São Paulo: Quartier Latin, 2005, pág. 450 - 523.

FERRAZ JUNIOR, Tércio Sampaio. Introdução ao estudo do direito: técnica, decisão, dominação. $6^{\mathrm{a}}$ ed., São Paulo, Atlas, 2010.

FERREIRA, Jussara Susi Assis Borges Nasser; RIBEIRO, Maria de Fátima. (Org.). Empreendimentos econômicos e desenvolvimento sustentável. São Paulo, Arte \& Ciência Editora, 2008.

FERREIRA FILHO, Manoel Gonçalves. Curso de direito constitucional. 38 ed., São Paulo: Saraiva, 2012.

FERREIRO LAPATZA, José Juan. Direito tributário: teoria geral do tributo. Barueri, SP: Manole; Espanha, ES: Marcial Pons, 2007.

FREITAS, Juarez. A interpretação sistemática do direito. $5^{\mathrm{a}}$ ed., São Paulo: Malheiros Editores, 2010. . Sustentabilidade: direito ao futuro. Belo Horizonte: Fórum, 2011.

FIORILLO, Celso Antonio Pacheco. FERREIRA, Renata Marques. Direito ambiental tributário. São Paulo: Saraiva, 2005.

FULGHESU, Giuseppina. La fiscalita' ambientale. Quaderno n. 6/2010. Università degli Studi di Foggia. Disponível em: http://www.dseagmeg.unifg.it/pubblicazioni/quaderni.asp acessado em 12.12.2013.

FURTADO, Celso. O mito do desenvolvimento econômico. São Paulo: Editora Círculo do Livro S.A., sem data.

. Teoria e política do desenvolvimento econômico. São Paulo: Editora Nacional, 1967.

ELALI, André de Souza Dantas. Tributação e desenvolvimento econômico regional, um exame da tributação como instrumento de regulação econômica na busca da redução das desigualdades regionais. São Paulo: MP Ed., 2007.

GRAU, Eros Roberto. A ordem econômica na constituição de $1988.13^{\text {a }}$ ed., São Paulo, Malheiros Editores, 2008. 
. Ensaio e discurso sobre a interpretação/aplicação do direito. $5^{\mathrm{a}}$ ed., São Paulo: Malheiros Editores, 2009.

HACK, Erico e FERRAZ, Roberto. "O princípio da capacidade contributiva e a tributação ambientalmente orientada", in Revista Direito Tributário Atual, vol. 21, São Paulo, Dialética e IBDT - Instituto Brasileiro de Direito Tributário, 2007, pp. 211 - 232.

HERRERO, Luis M. Jiménez. Tendencias en el uso de instrumentos económicos y fiscales em la gestión ambiental: reflexiones sobre la Unión Europea y el caso español. In: Fiscalidad Ambiental. Edición a cargo de STERLING, Ana Yábar. Espanha: Cedecs Editorial, 1998, p. 163 - 188.

HERNÁNDEZ, Héctor H. Valor y derecho, introducción axiológica a la filosofia jurídica. Buenos Aires, Abeledo - Perrot, 1998.

HERNÁNDEZ, Jorge Jiménez. El tributo como instrumento de protección ambiental. Granada, Editorial Comares, S.L., 1998.

HESSE, Konrad. Temas fundamentais do direito constitucional. Textos selecionados e traduzidos por Carlos dos Santos Almeida, Gilmar Ferreira Mendes, Inocêncio Mártires Coelho. São Paulo: Saraiva, 2009.

HOFFMANN, Susy Gomes. As contribuições no sistema constitucional tributário. Campinas, SP: Copola, 1996.

HORVATH, Estevão. Contribuições de intervenção no domínio econômico. São Paulo: Dialética, 2009.

JARACH, Dino. O fato imponível: teoria geral do direito tributário substantivo. tradução de Dejalma Campos, São Paulo, Editora Revista dos Tribunais, 2004.

KAHN, Jon. Economics instruments to abate acidification in Sweden. In: Papers frorm Dublin Workshop, Environmental Taxes \& Charges, National Experiences \& Plans, European Foundation, 1996, pág. 113 - 120.

KLUTH, Winfried. Protección del medio ambiente mediante tributos ecológicos en la Republica Federal Alemana. In: In: Fiscalidad Ambiental. Edición a cargo de STERLING, Ana Yábar. Espanha: Cedecs Editorial, 1998, p. 189 - 206.

KRISTENSEN, Jens Pagter. Environmental taxes, tax reform and the internal market - some danish expeciences and possible community initiatives. In: Papers frorm Dublin Workshop, Environmental Taxes \& Charges, National Experiences \& Plans, European Foundation, 1996, p. 121 -136.

LARENZ, Karl. Metodologia da ciência do direito. Tradução de José Lamengo, $5^{\text {a }}$ edição, Lisboa, Fundação Calouste Gulbenkian, 2009. 
LIMA, Ricardo Siebel de Freitas. Livre concorrência e o dever de neutralidade tributária. Dissertação de Mestrado apresentada na Universidade Federal do Rio Grande do Sul - UFRGS, Porto Alegre, 2005.

MACHADO, Hudo de Brito. Ordem econômica e tributação. In FERRAZ, Roberto Catalano Botelho (coord.) - Princípios e limites da tributação 2 - Os princípios da Ordem Econômica e a tributação. São Paulo: Quartier Latin, 2009, pág. 375 - 396.

MAFFEZZONI, Federico. Il principio di capacità contributiva nel diritto finanziario. Torino: Unione Tipografico - Editrice Torinese, 1970.

MAIA, Alexandre Aguiar (coord.). Tributação ambiental. Fortaleza, Tipropresso, 2009.

MANEIRA, Eduardo. Praticidade tributária. In: TÔRRES, Heleno Taveira (coord.). direito tributário e ordem econômica, homenagem aos 60 anos da ABDF. São Paulo: Quartier Latin, 2010. p. 379-396.

MARINS, James (coord.). Tributação e meio ambiente. Curitiba: Juruá, 2003.

MARQUES, Márcio Severo. Classificação constitucional dos tributos. São Paulo: Max Limonad, 2000.

MARTINS, Ives Gandra da Silva (Org.). Contribuições no domínio econômico. Conferencista inaugural José Carlos Moreira Alves. São Paulo: Editora Revista dos Tribunais, 2002. (Pesquisas Tributárias. Nova série; 8).

MARTINEZ, Sergio Rodrigo e RIBEIRO, Marcia Carla Pereira (coord.). Desenvolvimento e o meio ambiente: o pensamento de econômico de Amartya Sen. Belo Horizonte: Forúm, 2011.

MARTÍNEZ ALIER, Joan y JUSMET, Jordi Roca. Economía ecológica y política ambiental. $2^{\mathrm{a}}$ ed., México: FCE, 2001.

MARTUL-ORTEGA, Perfecto Yebra. Los fines extrafiscais del impuesto. In Tratado de Derecho Tributario, tomo primero El Derecho Tributario e Sus Fuentes. AMATUCCI, Andrea (coord.). Editorial Temis S.A.: Bogotá-Colombia, 2001, 355 - 387.

MELO, José Eduardo Soares de. Contribuições sociais no sistema tributário. $6^{\mathrm{a}}$ ed., São Paulo: Malheiros Editores, 2010.

MELLO, Celso Antonio Bandeira de. Conteúdo jurídico do princípio da igualdade. $3^{\mathrm{a}}$ ed., São Paulo, Malheiros Editores, 2009. - Eficácia das normas constitucionais e direitos sociais. São Paulo: Malheiros Editores, 2009. 
MENDES, Gilmar Ferreira. Curso de direito constitucional. São Paulo: Saraiva, 2007.

MITA, Enrico De. O Princípio da Capacidade Contributiva. Tradução de Roberto Ferraz. In Princípios e Limites da Tributação. FERRAZ, Roberto Catalano Botelho (coord.). São Paulo: Quartier Latin, 2005, pág. 223 - 256.

MODÉ, Fernando Magalhães. Tributação ambiental - a função do tributo na proteção do meio ambiente. Curitiba, Juruá, 2004.

MOLINA, Pedro M. Herrera. Derecho tributario ambiental (environmental tax law) La introducción del interes ambiental en el ordenamiento tributario. Madrid, Marcial Pons, 2000.

MOLL, Luíza Helena. Externalidades e apropriação: projeções sobre o direito econômico na nova ordem mundial. In Desenvolvimento econômico e intervenção do Estado na ordem constitucional, estudos jurídicos em homenagem ao Professor Washington Peluso Albino de Souza. Porto Alegre, Sergio Antonio Fabris Editor, 1995.

MONCADA, Luís S. Cabral de. Direito econômico. $5^{\mathrm{a}}$ ed., Coimbra, Coimbra Editora, 2007.

MORO, Cristóbal J. Borrero. La tributación ambiental en españa. Madrid, Editorial Tecnos, S.A., 1999.

La materia Imponible en los tributos extrafiscales. ¿Presupeusto de realización de la autonomia financiera? Navarra, Editorial Aranzadi, 2004.

MOSCHETTI, Francesco. La capacità contributiva, Profili Generali. In La capacità contributiva, a cura di Francesco Moschetti. Padova: CEDAM, 1993, pág. 3 - 51.

. El principio de capacidad contributiva. In Tratado de Derecho Tributario, tomo primero El Derecho Tributario e Sus Fuentes. AMATUCCI, Andrea (coord.). Editorial Temis S.A.: Bogotá-Colombia, 2001, 240 - 284.

NAHMEN, Frank van. Effective formulation of tax laws taking environmental considerations into account. In: In: Papers frorm Dublin Workshop, Environmental Taxes \& Charges, National Experiences \& Plans, European Foundation, 1996, p. 195 - 199.

NERI, Aimée Figueroa. Tributos ambientales en méxico. Una revisión de su evolución y problemas. In: Boletín Mexicano de Derecho Comparado, nueva serie, año XXXVIII, núm. 114, septiembre-diciembre de 2005, pp. 991-1020, disponível em: http://www.redalyc.org/articulo.oa?id=42711402 acessado em 14.12.2013.

NETO, Jayme Barboza de Freitas; BUENO, Luís Felipe Krieger Moura; COSTA, Luiz Eugênio Porto Severo da. O Tributo Ambiental à Luz do Direito Comparado. In 
ORLANDO, Breno Ladeira Kingma; GUDIÑO, Daniel Mariz; TROUW, Ernesto Johannes; GONÇALVES, Fábio Fraga; MUNIZ, Igor; MURAYAMA, Janssen Hiroshi. (Coord.). Direito Tributário Ambiental, Rio de Janeiro, Lumen Juris, 2006, pp. 57 - 78.

NOGUEIRA, Ruy Barbosa. Da interpretação e da aplicação das leis tributárias. $2^{\mathrm{a}}$ ed., São Paulo: Editora Revista dos Tribunais, 1965.

Direito tributário comparado. São Paulo: Saraiva, 1971.

Curso de Direito Tributário. $4^{\mathrm{a}}$ ed., São Paulo, Instituto Brasileiro de Direito Tributário - IBDT, entidade complementar à Universidade de São Paulo, 1976.

- Princípio da seletividade do tributo em função da essencialidade do produto - Incidência, não incidência, isenção e imunidade tributária, in Revista dos Tribunais, n. 651, v. 79, São Paulo, 1990, pág. 7 - 15.

NUNES, Cleucio Santos. Direito tributário e meio ambiente. São Paulo, Dialética, 2005.

NUNES, Vidal Serrano. Direito constitucional tributário. v. 1. São Paulo: Didática, s/d.

NUSDEO, Ana Maria de Oliveira. O uso de instrumentos econômicos nas normas de proteção ambiental. In Revista da Faculdade de Direito, Universidade de São Paulo, v. 101, 2006, pág. $357-378$.

NUSDEO, Fábio. Desenvolvimento e ecologia. São Paulo, Saraiva, 1975.

. Curso de economia: introdução ao direito econômico. $2^{\mathrm{a}}$ ed., São Paulo, Editora Revista dos Tribunais, 2000.

- Economia e meio ambiente. In Curso interdisciplinar de Direito Ambiental. PHILIPPI Jr.; Arlindo; ALVES, Alaôr Caffé (editores). Barueri, SP: Manole, 2005, pág. $193-213$.

- Direito Econômico Ambiental. In Curso interdisciplinar de Direito Ambiental. PHILIPPI Jr.; Arlindo; ALVES, Alaôr Caffé (editores). Barueri, SP: Manole, 2005, pág. 717- 738

NYE, John V.C. "The Pigou problem", in Regulation, Vol. 31, N". 2, Summer 2008, pág. 32-37, extraído do sítio eletrônico SSRN: http://ssrn.com/abstract=1241542, em 15.11.2012.

OCDE, El sistema tributario, la innovación y el medio ambiente. 2010. http://www.keepeek.com/Digital-Asset-Management/oecd/environment/el-sistematributario-la-innovacion-y-el-medio-ambiente 9789264208193-es\#page4 
OLIVEIRA, Ary Brandão. Direitos sociais vs desenvolvimento nacional. In SCAFF, Fernando Facury. (coord.), Ordem econômica e social: estudos em homenagem a Ary Brandão de Oliveira, São Paulo: LTr, 1999, pág. 75 - 107.

OLIVEIRA, José Marcos Domingues. Direito tributário e meio ambiente, proporcionalidade, tipicidade aberta e afetação da receita. Rio de Janeiro, Renovar, 1995. . "Proteção ambiental e sistema tributário - Brasil e Japão: Problemas em Comum", in Tributação e Meio Ambiente. MARINS, James. (Coord.). Curitiba, Editora Juruá, 2003, pp. 103 - 120.

OLIVEIRA, Regis Fernandes. Curso de direito financeiro. $5^{\mathrm{a}}$ ed., São Paulo: Editora Revista dos Tribunais, 2013.

ORTE, Jaime Fernández. La tributación medioambiental, teoría y práctica. Navarra - Espanha: Editorial Aranzadi, S.A. 2006.

OVIDEO, Juan Ignacio Gorospe. "La fiscalidad de los derechos de emisión en España", in XXV Jornadas Larinoamericanas y XXXIV Colombianas de Derecho Tributario: Foros y Debates, Cartagena de Indias, Colombia, 14-19 de febrero de 2010, pp. 77-114.

PAIVA, Leila. Disciplina jurídica da extrafiscalidade. Dissertação de Mestrado da Faculdade de Direito da USP. São Paulo, sem data.

PARETO, Vilfredo. Manual de economia política. Tradução de João Guilherme Vargas Netto. Editora Nova Cultural, 1996.

PETTER, Lafayete Josué. Princípios constitucionais da ordem econômica: o significado e o alcance do art. 170 da Constituição Federal. 2a ed., São Paulo: Editora Revista dos Tribunais, 2008.

PIGOU, Arthur C. The economics of welfare. $4^{\text {th }}$ ed., London: McMillan, 1932.

PIMENTA, Paulo Roberto Lyrio. Contribuições de intervenção no domínio econômico. São Paulo: Dialética, 2002.

PINTO, Flávia Sousa Dantas. Regra-matriz das contribuições: uma proposta. In: MARTINS, Ives Gandra da Silva; ELALI, André (coord.) Elementos atuais de direito tributário: estudos e conferências. Curitiba: Juruá, 2005.

PIRES, Adilson Rodrigues. Manual de direito tributário. 9. ed. Rio de Janeiro: Forense, 1996.

PITTEVILS, Ivan. Ecotaxes on products in Blegium: the need for a proper point of imposition. In: Papers frorm Dublin Workshop, Environmental Taxes \& Charges, National Experiences \& Plans, European Foundation, 1996, p. 201 - 209. 
PORFÍRIO JÚNIOR, Nelson de Freitas. Responsabilidade do Estado em face do dano ambiental. Dissertação de Mestrado da Faculdade de Direito da USP. São Paulo, 1999.

RAMOS FILHO, Carlos Alberto. Curso de direito financeiro. São Paulo: Saraiva, 2012 .

RANIERI, Nina Beatriz Stoco. Teoria do Estado: do Estado de Direito ao Estado Democrático de Direito. Barueri, SP: Manole, 2013.

RAZ, Joseph. O conceito de sistema jurídico: uma introdução à teoria dos sistemas jurídicos. Tradução de Maria Cecília Almeida; revisão de tradução de Marcelo Brandão Cipolla. - São Paulo: Editora WMF Mrtins Fontes, 2012.

REALI, Darcí. Os municípios e a tributação ambiental. Caxias do Sul, RS: Educs, 2006.

RIBAS, Lídia Maria Lopes Rodrigues. Defesa ambiental: utilização de instrumentos tributários. In TÔRRES, Heleno Taveira. Direito tributário ambiental. São Paulo: Malheiros Editores, 2005, pág. 675 - 723.

RIBEIRO, Maria de Fátima; e FERREIRA, Jussara S. Assis Borges Nasser. O papel do Estado no desenvolvimento econômico sustentável: reflexões sobre a tributação ambiental como instrumento de políticas públicas. In TÔRRES, Heleno Taveira (org.). Direito tributário ambiental. São Paulo: Malheiros Editores, 2005, pág. 653 - 673.

ROCHA, Valdir de Oliveira. Determinação do montante do tributo: quantificação, fixação e avaliação. 2. ed. São Paulo: Dialética, 1995, p. 119.

RODRIGUES, Marilene Talarico Martins. Contribuições de intervenção no domínio econômico. In: MARTINS, Ives Gandra da Silva (coord.). Contribuições de intervenção no domínio econômico. São Paulo: Ed. Revista dos Tribunais: Centro de Extensão Universitária, 2002.

ROSEMBUJ, Tulio. Los tributos y la protección del medio ambiente. Madrid, Marcial Pons Ediciones Juridicas, S.A., 1995.

ROTHMANN, Gerd Willi. O princípio da legalidade tributária. In: Direito Tributário: estudo de casos e problemas. $5^{\text {a }}$ coletânea, direção e colaboração do Prof. Ruy Barbosa Nogueira, Bushatsky, 1973. . Tributação, Sonegação e Livre Concorrência. In: Princípios e Limites da Tributação 2 - Os Princípios da Ordem Econômica e a Tributação. FERRAZ, Roberto Catalano Botelho (coord.). São Paulo: Quartier Latin, 2009, pág. 331 - 372. 
SALIBA, Ricardo Berzosa. Fundamentos do direito tributário ambiental. São Paulo, Quartier Latin, 2005.

SANTI, Eurico Marcos Diniz de. As classificações no sistema tributário brasileiro. In: Justiça tributária: direitos do fisco e garantias dos contribuintes nos atos da administração e no processo tributário. São Paulo: Max Limonad, 1998.

SANTIAGO, Myrian Passos. Tributação do ilícito. Belo Horizonte, Del Rey, 2005.

SANTOS, António Carlos dos. Auxílios de Estado e fiscalidade. Livraria Almedina: Coimbra, 2003.

SARLET, Ingo Wolfgang e FENSTERSEIFER, Tiago. Direito constitucional ambiental: Constituição, direitos fundamentais e proteção do ambiente. $2^{\mathrm{a}}$ ed., São Paulo: Editora Revista dos Tribunais, 2012.

SARLET, Ingo Wolfgang (Organizador). Estado socioambiental e direitos fundamentais. Porto Alegre: Livraria do Advogado Editora, 2010.

SCAFF, Fernando Facury. Responsabilidade do estado intervencionista. São Paulo: Saraiva, 1990.

; ATHIAS, Jorge Alex (Coord.). Direito tributário e econômico aplicado ao meio ambiente e à mineração. São Paulo, Quartier Latin, 2009.

; TUPIASSU, Lise Vieira da Costa. Tributação e políticas públicas: o ICMS ecológico, in Direito tributário ambiental. TÔRRES, Heleno Taveira (org.). São Paulo: Malheiros Editores, 2005, pág. 724 - 748.

SCHOUERI, Luis Eduardo. Normas tributárias indutoras em matéria ambiental, In TÔRRES, Heleno Taveira. (Org.). Direito tributário ambiental. São Paulo, Malheiros Editores, 2005, pp. 235 - 253.

. Tributação e indução econômica: os efeitos econômicos de um tributo como critério para sua constitucionalidade. In FERRAZ, Roberto Catalano Botelho (coord.) - Princípios e limites da tributação 2 - Os princípios da Ordem Econômica e a Tributação. São Paulo: Quartier Latin, 2009, p. 139 - 164.

. Normas tributárias indutoras e intervenção econômica. Rio de Janeiro, Editora Forense, 2005.

. Direito tributário. São Paulo, Saraiva, 2011.

SCHMÖLDERS, Günter. Teoria general del impuesto. Traducción de Luis A. Martín Merino, Madrid: Editorial de Derecho Financiero, 1962.

SCOTT. Paulo Henrique Rocha. Direito constitucional econômico: Estado e normalização da economia. Porto Alegre, Sergio Antonio Fabris Editor, 2000. 
SEBASTIÃO, Simone Martins. Tributo ambiental. Curitiba, Editora Juruá, 2007.

SEN, Amartya. Desenvolvimento como liberdade. Tradução de Laura Teixeira Motta; revisão técnica Ricardo Doniselli Mendes. São Paulo: Companhia das Letras, 2000.

SHOME, Parthasanranthi. The tax base: a 21 century global carbon tax. In Bulletin for International Fiscal Documentation. Nov./Dec., 1996, pp. 481-489.

SILVA, Daniely Andressa da. Tributos verdes: proteção ambiental ou uma nova roupagem para antigas finalidades? In Revista do Instituto do Direito Brasileiro, Ano 1, $\mathrm{n}^{\circ}$ 8, Lisboa, 2012, p. 4993-5023.

SILVA, Joana Lins e. Fundamentos da norma tributária. São Paulo: Max Limonad, 2001.

SILVA, José Afonso da. Aplicabilidade das normas constitucionais. $7^{a}$ ed., São Paulo, Malheiros Editores, 2009.

. Curso de direito constitucional. 33a ed., São Paulo, Malheiros Editores, 2010.

Direito ambiental constitucional. $8^{\mathrm{a}}$ ed., São Paulo, Malheiros Editores, 2010.

. Um pouco de direito constitucional comparado. São Paulo, Malheiros Editores, 2009.

SILVA, Virgílio Afonso da. Direitos fundamentais, conteúdo essencial, restrições e eficácia. $2^{\mathrm{a}}$ ed., São Paulo: Malheiros Editores, 2010.

SOARES, Claudia Alexandra Dias. O imposto ecológico - contributo para o estudo dos instrumentos econômicos de defesa do ambiente. Coimbra, Coimbra Editora, 2001.

SOUZA, Jorge Henrique de Oliveira. Tributação e meio ambiente. Belo Horizonte, Del Rey, 2009.

SOUZA, Rafael Pereira de (coord.). Aquecimento global e créditos de carbono aspectos jurídicos e técnicos. São Paulo, Quartier Latin, 2007.

SOUZA, Ricardo Conceição. Regime jurídico das contribuições. São Paulo: Dialética, 2002.

SOUZA, Rubens Gomes de. Compêndio de legislação tributária; coordenação: IBET, Instituto Brasileiro de Estudos Tributários; obra póstuma. São Paulo, Ed. Resenha Tributária, 1975.

SOUZA, Washington Peluso Albino. Lições de direito econômico. Porto Alegre, Sergio Antonio Fabris Editor, 2002. 
SQUILLANTE, Dea, Evoluzione del concetto di tributo ambientale: prospettive interne e comunitarie. Tesi di Dottorato di Ricerca, Facoltà di Giurisprudenza, Università Degli Studi di Napoli "FEDERICO II", 2008, disponível em: http://www.fedoa.unina.it/2761/ acessado em 15.12.2013.

STELO, Gilmar. Política tributária e meio ambiente. Brasília, OAB Editora, 2009.

STIGLITZ, Joseph E., Economics of the public sector. $3^{\mathrm{a}}$ ed., New York: Norton \& Company, Inc., 2000.

TAVARES, André Ramos. Curso de direito constitucional. 9a ed., São Paulo: Saraiva, 2011.

Direito constitucional econômico. $3^{\mathrm{a}}$ ed., Rio de Janeiro: Forense; São Paulo: MÉTODO, 2011.

TILBERY, Henry. Conceito de essencialidade como critério de tributação, in Direito Tributário Atual Vol. 10: São Paulo, Resenha Tributária, 1990, pág. 2969 - 3035.

TIPKE, Klaus. Princípio de igualdade e idéia de sistema no direito tributário, in MACHADO, Brandão (coord.). Direito Tributário: estudos em homenagem ao Prof. Rui Barbosa Nogueira. São Paulo: Saraiva, 1984, pág. 515 - 527.

. e YAMASHITA, Douglas, Justiça fiscal e princípio da capacidade contributiva. São Paulo, Malheiros Editores, 2002.

Direito Tributário. Tradução da $18^{\mathrm{a}}$ ed. alemã, totalmente refeita, de Luiz Doria Furquim. Porto Alegre: Sergio Antonio Fabris Ed., 2008.

Moral tributária do estado e dos contribuintes. Tradução de Luiz dória Furquim. Porto Alegre: Sergio Antonio Fabris Ed., 2012.

A necessidade de igualdade na execução das leis tributárias. In SCHOUERI, Luís Eduardo (coord.). Direito tributário, Vol. I - Homenagem a Alcides Jorge Costa. São Paulo: Quartier Latin, 2003, p. 361- 374.

TÔRRES, Heleno Taveira. Pressupostos constitucionais das contribuições de intervenção no domínio econômico. A Cide-Tecnologia. In: ROCHA, Valdir de Oliveira (coord.). Grandes questões atuais do direito tributário. $7^{\circ}$ v. São Paulo: Dialética, 2003.

TORRES, Ricardo Lobo. Valores e princípios no direito tributário ambiental. In TÔRRES, Heleno Taveira (org.). Direito tributário ambiental. São Paulo, Malheiros Editores, 2005.

O direito ao mínimo existencial. Rio de Janeiro: Renovar, 2009.

. Curso de direito financeiro e tributário. $18^{\mathrm{a}}$ ed., Rio de Janeiro: Renovar, 
Tratado de direito constitucional financeiro e tributário. vol. I Constituição financeira, sistema tributário e estado fiscal. Rio de Janeiro: Renovar, 2009. . Tratado de direito constitucional financeiro e tributário. vol. II - Valores e princípios constitucionais tributários. Rio de Janeiro: Renovar, 2005.

A legitimação da capacidade contributiva e dos direitos fundamentais do contribuinte. In SCHOUERI, Luís Eduardo (coord.). Direito tributário, Vol. I Homenagem a Alcides Jorge Costa. São Paulo: Quartier Latin, 2003, p. 429- 456.

. Princípios e teoria geral do direito tributário ambiental. In: TÔRRES, Heleno Taveira (org.). Direito tributário ambiental. São Paulo: Malheiros Editores, 2005, p. $21-54$.

TOSI, Loris. Efectividade. Aspectos subjetivos y objetivos de la capacidad contributiva. In Tratado de Derecho Tributario, tomo primero El Derecho Tributario e Sus Fuentes. AMATUCCI, Andrea (coord.). Editorial Temis S.A.: Bogotá-Colombia, 2001, $285-339$.

TUPIASSU, Lise Vieira da Costa. Tributação ambiental: a utilização de instrumentos econômicos e fiscais na implementação do direito ao meio ambiente saudável. Rio de Janeiro, Renovar, 2006.

UCKMAR, Victor. Princípios comuns de direito constitucional tributário. São Paulo. Editora Revista dos Tribunais, EDUC, 1976.

VALCÁRCEL, Ernesto Lejeune. El principio de igualdad. In Tratado de Derecho Tributario, tomo primero El Derecho Tributario e Sus Fuentes. AMATUCCI, Andrea (coord.). Editorial Temis S.A.: Bogotá-Colombia, 2001, 221- 239.

VANONI, Ezio. Natureza e interpretação das leis tributárias. Tradução de Rubens Gomes de Sousa. Rio de Janeiro: Edições Financeiras S.A.,

VILLEGAS, Héctor Belisario. Curso de finanzas, derecho financeiro y tributário. 9a ed., Buenos Aires, Editorial Astrea de Alfredo y Ricardo Depalma, 2009.

VOGEL, Klaus. Tributos regulatórios e garantia da propriedade no direito constitucional da República Federal da Alemanha. In Direito Tributário: estudos em homenagem ao Prof. Rui Barbosa Nogueira. MACHADO, Brandão (coord.). São Paulo: Saraiva, 1984, pág. $541-554$.

WINTER, Gerd. Desenvolvimento sustentável, OGM e responsabilidade civil na União Europeia. Tradução: Carol Manzoli Palma. Campinas, SP: Millennium Editora, 2009. 
YAMASHITA, Douglas. Princípio da solidariedade em direito tributário. In Solidariedade Social e Tributação. GRECO, Marco Aurélio; GODOI, Marciano Seabra de. São Paulo: Dialética, 2005, pág. 53- 67.

YANDLE, Bruce. Public choice at the intersection of environmental Law and economics. In European Journal of Law and Economics. N. 8, Netherlands, 1999, p. 5 27.

ZILVETI, Fernando Aurélio. Princípios de direito tributário e a capacidade contributiva. São Paulo. Quartier Latin, 2004. 